medRxiv preprint doi: https://doi.org/10.1101/2020.08.03.20167544; this version posted August 4, 2020. The copyright holder for this preprint (which was not certified by peer review) is the author/funder, who has granted medRxiv a license to display the preprint in perpetuity.

All rights reserved. No reuse allowed without permission.

\title{
The Bacterial and Viral Complexity of Postinfectious Hydrocephalus in Uganda
}

Joseph N. Paulson ${ }^{1^{*}}$, Brent L. Williams ${ }^{2,23^{*}}$, Christine Hehnly ${ }^{3^{*}}$, Nischay Mishra ${ }^{2,23^{*}}$, Shamim A. Sinnar ${ }^{4,5^{*}}$, Lijun Zhang ${ }^{3^{*}}$, Paddy Ssentongo ${ }^{4,6,7^{*}}$, Edith Mbabazi-Kabachelor ${ }^{*}$, Dona S. S. Wijetunge ${ }^{9^{*}}$, Benjamin von Bredow ${ }^{9^{*}}$, Ronnie Mulondo ${ }^{8^{*}}$, Julius Kiwanuka ${ }^{10^{*} \dagger}$, Francis Bajunirwe ${ }^{11}$, Joel Bazira ${ }^{12}$, Lisa M. Bebell ${ }^{13}$, Kathy Burgoine ${ }^{14,15,16}$, Mara Couto-Rodriguez 2,17, Jessica E. Ericson ${ }^{18}$, Tim Erickson ${ }^{8}$, Matthew Ferrari ${ }^{19,20}$, Melissa Gladstone ${ }^{21}$, Cheng Guo ${ }^{2}$, Murali Haran ${ }^{22}$, Mady Hornig ${ }^{23}$, Albert M. Isaacs ${ }^{24}$, Brian Nsubuga Kaaya ${ }^{8}$, Sheila M. Kangere ${ }^{8}$,Abhaya V. Kulkarni ${ }^{25}$, Elias Kumbakumba ${ }^{10}$, Xiaoxiao Li ${ }^{22}$, David D. Limbrick Jr. ${ }^{26}$, Joshua Magombe ${ }^{8}$, Sarah U. Morton ${ }^{27}$, John Mugamba ${ }^{8}$, James Ng ${ }^{2}$, Peter Olupot-Olupot ${ }^{15,28}$, Justin Onen ${ }^{8}$, Mallory R. Peterson, ${ }^{4,6}$, Farrah Roy ${ }^{29}$, Kathryn Sheldon ${ }^{3}$, Reid Townsend ${ }^{30}$, Andrew D. Weeks ${ }^{31}$, Andrew J. Whalen ${ }^{32}$, John Quackenbush ${ }^{29}$, Peter Ssenyonga ${ }^{8 \S}$, Michael Y. Galperin ${ }^{33 \S}$, Mathieu Almeida ${ }^{34 \S}$, Hannah Atkins ${ }^{35 \S}$, Benjamin C. Warf ${ }^{36 \S}$, W. Ian Lipkin $^{2,23 \S}$, James R. Broach ${ }^{3 \S}$, Steven J. Schiff $4,6,19,37,38 \S \neq$

May 6, 2020

\author{
*, Contributed Equally \\ ${ }^{\dagger}$ Deceased \\ ‡ To whom correspondence should be addressed: \\ Steven J. Schiff \\ W311 Millennium Science Complex \\ The Pennsylvania State University \\ University Park, PA 16802 USA \\ 814-863-4210 \\ steven.j.schiff@gmail.com
}

1 Department of Biostatistics, Product Development, Genentech Inc.

2 Center for Infection and Immunity, Mailman School of Public Health, Columbia University

3 Institute for Personalized Medicine, Dept. of Biochemistry and Molecular Biology, The Pennsylvania State University College of Medicine

4 Center for Neural Engineering, The Pennsylvania State University

5 Department of Medicine, The Pennsylvania State University College of Medicine

6 Department of Engineering Science and Mechanics, The Pennsylvania State University

7 Department of Public Health Sciences, The Pennsylvania State University College of Medicine

8 CURE Children's Hospital of Uganda

9 Department of Pathology, The Pennsylvania State University College of Medicine

10 Department of Pediatrics, Mbarara University of Science and Technology

11 Department of Epidemiology, Mbarara University of Science and Technology

12 Department of Microbiology, Mbarara University of Science and Technology

13 MGH Medical Practice Evaluation Center, Division of Infectious Diseases, and Center for Global Health

14 Neonatal Unit, Department of Paediatrics and Child Health, Mbale Regional Referral Hospital, Mbale, Uganda

15 Mbale Clinical Research Institute, Mbale Regional Referral Hospital, Mbale, Uganda

16 University of Liverpool, Liverpool, UK

17 Biotia, 100 6th avenue, New York, NY, USA

18 Division of Pediatric Infectious Disease, The Pennsylvania State University College of Medicine 
medRxiv preprint doi: https://doi.org/10.1101/2020.08.03.20167544; this version posted August 4, 2020. The copyright holder for this preprint

(which was not certified by peer review) is the author/funder, who has granted medRxiv a license to display the preprint in perpetuity.

All rights reserved. No reuse allowed without permission.

19 The Center for Infectious Disease Dynamics, The Pennsylvania State University

20 Departments of Biology and Statistics, The Pennsylvania State University

21 Institute for Translational Medicine, University of Liverpool

22 Department of Statistics, The Pennsylvania State University

23 Department of Epidemiology, Columbia University Mailman School of Public Health

24 Department of Neuroscience, Washington University School of Medicine

25 Department of Neurosurgery, University of Toronto

26 Department of Neurological Surgery, Washington University School of Medicine

27 Division of Newborn Medicine, Boston Children's Hospital and Department of Pediatrics, Harvard Medical School

28 Busitema University, Faculty of Health Sciences, Mbale Campus 2

29 Department of Biostatistics, Harvard T.H. Chan School of Public Health

30 Department of Medicine, Washington University School of Medicine

31 Department of Women's and Children's Health, University of Liverpool and Liverpool Women's Hospital for Liverpool Health Partners, Liverpool, UK

32 Department of Mechanical Engineering, The Pennsylvania State University

33 National Center for Biotechnology Information, National Library of Medicine, National Institutes of Health

34 MGP MetaGénoPolis, INRA, Université Paris-Saclay

35 Department of Comparative Medicine, The Pennsylvania State University College of Medicine

36 Dept. of Neurosurgery, Boston Children's Hospital, Harvard Medical School

37 Department of Neurosurgery, The Pennsylvania State University College of Medicine

38 Department of Physics, The Pennsylvania State University 
medRxiv preprint doi: https://doi.org/10.1101/2020.08.03.20167544; this version posted August 4, 2020. The copyright holder for this preprint

(which was not certified by peer review) is the author/funder, who has granted medRxiv a license to display the preprint in perpetuity.

All rights reserved. No reuse allowed without permission.

\section{One Sentence Summary:}

We have discovered a novel strain of bacteria upon a frequent viral background underlying postinfectious hydrocephalus in Uganda.

\section{Abstract}

Postinfectious hydrocephalus (PIH), often following neonatal sepsis, is the most common cause of pediatric hydrocephalus world-wide, yet the microbial pathogens remain uncharacterized. Characterization of the microbial agents causing PIH would lead to an emphasis shift from surgical palliation of cerebrospinal fluid (CSF) accumulation to prevention. We examined blood and CSF from 100 consecutive cases of PIH and control cases of nonpostinfectious hydrocephalus (NPIH) in infants in Uganda. Genomic testing was undertaken for bacterial, fungal, and parasitic DNA, DNA and RNA sequencing for viral identification, and extensive bacterial culture recovery. We uncovered a major contribution to $\mathrm{PIH}$ from Paenibacillus, upon a background of frequent cytomegalovirus (CMV) infection. CMV was only found in CSF in PIH cases. A facultatively anaerobic isolate was recovered. Assembly of the genome revealed a strain of $P$. thiaminolyticus. In mice, this isolate designated strain Mbale, was lethal in contrast with the benign reference strain. These findings point to the value of an unbiased pan-microbial approach to characterize $\mathrm{PIH}$ in settings where the organisms remain unknown, and enables a pathway towards more optimal treatment and prevention of the proximate neonatal infections. 
medRxiv preprint doi: https://doi.org/10.1101/2020.08.03.20167544; this version posted August 4, 2020. The copyright holder for this preprint (which was not certified by peer review) is the author/funder, who has granted medRxiv a license to display the preprint in perpetuity.

All rights reserved. No reuse allowed without permission.

\section{Introduction}

Hydrocephalus is the most common indication for neurosurgery in children. Of the estimated 400,000 new cases each year, about half are estimated to be postinfectious, with the largest number of cases in low- and middle-income countries, especially sub-Saharan Africa (1). Neonatal sepsis (2) often precedes postinfectious hydrocephalus (PIH) (3), although the manifestations of hydrocephalus typically emerge in the months following the neonatal period as sufficient cerebrospinal fluid (CSF) accumulates so that cranial expansion garners medical attention. Thus, although these infants will typically die in early childhood without advanced surgical management, they are omitted from neonatal mortality surveillance (4).

The spectrum of microbial agents that underlie PIH remains poorly characterized. It is known that seasonal Neisseria epidemics can produce such cases within the African meningitis belt (5), and there have been reports of a tendency towards gram negative coliform bacteria in infants in other Southern (6) and Eastern (7) African locations where Neisseria is uncommon. Nevertheless, there has never been a well-controlled examination of the agents underlying $\mathrm{PIH}$, and no knowledge of the roles that viruses, parasites, or fungi might play in addition to bacteria. If the microbial agents causing PIH were better characterized, emphasis could shift from high technology palliation of CSF accumulation (8) to prevention.

In this study, we examined blood and CSF from 100 consecutive cases of $\mathrm{PIH}$ and control non-postinfectious hydrocephalus (NPIH) in infants under 3 months of age at the CURE Children's Hospital of Uganda (CCHU) in Mbale, Uganda. Since 2001, this pediatric neurosurgical hospital has treated thousands of PIH and NPIH cases, with nearly uniformly negative recovery of putative pathogens through standard bacterial culture. In this study, we gathered high quality blood and CSF samples for molecular analysis, and comprehensive testing was undertaken for bacterial, fungal, and parasitic DNA, genomic and RNA transcript sequencing for viruses, in addition to extensive bacterial culture recovery efforts for taxonomic identification, genome assembly and virulence characterization.

\section{$\underline{\text { Results }}$}

\section{Demographics \& clinical characteristics}

Between March and November 2016, 115 consecutive patients were screened, and 15 were excluded for the following reasons: 8 did not give consent, 6 lived outside of Uganda (South Sudan and Kenya), and 1 weighed less than $2.5 \mathrm{~kg}$. A total of 100 patients 3 months of age or younger with hydrocephalus were enrolled; 64 with $\mathrm{PIH}$ and 36 with NPIH. PIH patients were on average several weeks older than NPIH patients (whose disorders were generally recognized at birth), and had higher peripheral and CSF white blood cell counts, lower blood hemoglobin and hematocrit levels, but were evenly distributed by sex and HIV exposure status (Table 1).

Prior to admission for hydrocephalus, 15 infants received antibiotics, but we only have records detailing antibiotic type for 2 of these 15 patients (gentamicin with ampicillin in one case and gentamicin with ceftriaxone in the other case). Three patients received antibiotics for treatment of active infection at CCHU after admission (ceftriaxone with gentamicin in one case, and ceftriaxone alone in the others). Such antibiotic treatment is adjunctive to abscess management (drainage and irrigation of larger accessible abscesses), prior to more definitive surgical treatment of hydrocephalus with endoscopic third ventriculostomy or insertion of a ventriculoperitoneal shunt (8).

Preoperative CT scans were scored, demonstrating that PIH patients were more likely to have evidence of CSF fluid loculations, debris within fluid spaces, ectopic calcification, and brain 
medRxiv preprint doi: https://doi.org/10.1101/2020.08.03.20167544; this version posted August 4, 2020. The copyright holder for this preprint (which was not certified by peer review) is the author/funder, who has granted medRxiv a license to display the preprint in perpetuity.

All rights reserved. No reuse allowed without permission.

abscesses (Table 1 and Fig. S1). The homes of PIH patients were concentrated within central and eastern Uganda, in a swampy plateau north of Lake Victoria, and south and north of the banks of Lake Kyoga, while NPIH patients were more uniformly distributed geographically (Fig. 1 and Fig. S2, $p=0.03$ by linear discrimination).

\section{Bacterial pathogen detection}

For bacterial pathogen discovery, both Sanger sequencing of 16S rDNA V1-V4 region and next generation sequencing of $\mathrm{V} 1-\mathrm{V} 2$ and $\mathrm{V} 4$ regions were performed on fresh frozen and preserved specimens in two different laboratories, which enabled us to account for known variation in microbial community amplicon sequencing (9), and demonstrate reproducibility of our findings.

Using DNA from fresh frozen CSF, conventional PCR targeting the V1-V4 16S rDNA gene region (Table S1) revealed $16 \mathrm{~S}$ amplification in $27 / 64 \mathrm{PIH}$ and only $3 / 36 \mathrm{NPIH}$ patients. V1-V4 Sanger sequencing of subcloned amplicons identified Paenibacillus as a predominant organism within the PIH cohort (23/64), but not within the NPIH cohort (0/36). The full results from this method are summarized in Table S2. For quantification of Paenibacillus in CSF, Paenibacillus genus-specific qPCR was performed confirming and quantifying 22 of the 23 samples that were positive for Paenibacillus by Sanger sequencing and identifying 4 additional positive cases (Fig. 2A and 2B). Next generation sequencing on $16 \mathrm{~S}$ rDNA V4 region was performed on all samples from which amplification libraries could be obtained with composite MiSeq primers (26/64 PIH and 3/36 NPIH) (Fig. 2C). Only a few nucleotides distinguished $P$. thiaminolyticus and $P$. popilliae within the $\mathrm{V} 1-\mathrm{V} 4$ region, hindering species-level discrimination between these taxa. From the V1-V4 sequencing data a phylogenetic tree was constructed, revealing that the majority of the Paenibacillus V1-V4 sequences were most closely related to $P$. thiaminolyticus and $P$. popilliae, and sequences from one subject that most closely matched $P$. alvei (Fig. S3).

Using DNA from samples in genomic preservative, next generation sequencing was performed on V1-V2. Overall, representative sequences from the 1,767 operational taxonomic units (OTUs) matched 159 genera. The majority of OTUs were sparsely represented except for a number of known skin flora, e.g., Propionibacterium spp. (Fig. 2D). Over half of the reads in $20 \%$ of the patients were attributed to the genus Paenibacillus. Paenibacillus spp. were present, defined as a minimum of 50 reads, in $38 \mathrm{PIH}$ patients and $2 \mathrm{NPIH}$ controls (Fig. 2D).

To associate taxa with infection we aggregated annotated OTUs at the genus level and performed differential abundance analysis. In performing linear regression analysis (Supplemental Methods: Differential Abundance Analysis), Paenibacillus was the only genus associated with PIH following multiple testing correction (Table S3). Paenibacillus spp. 16S rDNA abundance was used as a biomarker for classifying $\mathrm{PIH}$ patients and was consistent between $\mathrm{V} 1-\mathrm{V} 2$ and $\mathrm{V} 4$ (Fig. 2E). A receiver operating characteristic analysis yielded an area under the curve of $70.9 \%$ (95\% DeLong $\mathrm{Cl}=60.6 \%-81.1 \%$ ) for $\mathrm{V} 1-\mathrm{V} 2$ (Fig. 2F, Fig. S4A), with an optimal threshold just below 50 reads.

The spatial distribution of PIH and PIH Paenibacillus positive cases was significantly different from control NPIH cases (Fig. 1, Fig. S2).

Other putative pathogens detected by $16 \mathrm{~S}$ in individual patients at high abundance included sequences consistent with Bacillus subtilis and Streptococcus agalactiae (Fig. 2C and 2D, Table S2). Diversity decreased as Paenibacillus abundance increased (Fig. S4B). The majority of CSF samples had similar microbial background leading to no clear visual separation of $\mathrm{PIH}$ and NPIH when diversity (beta) was visualized with principal coordinates analysis (PCoA) plots to reduce the dimension (Fig. S4C). Limiting to the set of OTUs annotated as Paenibacillus spp. revealed two or three clusters of patients with similar Paenibacillus abundance distributions in positive patients (Fig. S5). Further analysis on the microbial 
medRxiv preprint doi: https://doi.org/10.1101/2020.08.03.20167544; this version posted August 4, 2020. The copyright holder for this preprint (which was not certified by peer review) is the author/funder, who has granted medRxiv a license to display the preprint in perpetuity.

All rights reserved. No reuse allowed without permission.

communities, including comparison of $16 \mathrm{~S}$ regions and the characterization of isolates' taxonomy, is described in Supplementary Methods (microbial characterization: taxonomic assignment and overview and differential abundance analysis).

\section{Viral pathogen detection}

Utilizing the targeted viral detection capture technique VirCapSeq-VERT (10), we observed evidence of 11 viral strains distributed across $36 \%$ of samples $-32.8 \%(\mathrm{PIH})$ and $41.6 \%$ (NPIH) (Table S4). Only Human Herpesvirus 5 (cytomegalovirus, CMV) was present at substantial abundance, confirmed by requiring positive findings on at least two replicates in two different qPCR methods (Supplementary Materials, Table S4) applied to all 100 preserved CSF and blood samples. CMV was confirmed in 27/100 patients (27/99 blood: 18/64 PIH, 9/35 NPIH), but CMV was found only in the CSF in blood CMV positive PIH cases (8/100 CSF: 8/64 $\mathrm{PIH}, 0 / 36 \mathrm{NPIH}$ ) (Fig. 3A). RNA sequence data confirmed 4 cases of CMV by sequence matches to multiple mRNA transcripts (Fig. 3A).

The spatial distribution of CMV positive cases was not significantly different from control NPIH cases (Fig. 1, Fig. S2).

\section{Paenibacillus correlates with clinical signs}

Several clinical measurements were positively associated with Paenibacillus presence including CSF cell count and CT scan scores.

In 12 months of follow-up, there were 5 deaths: $3 \mathrm{PIH}$ and 2 NPIH patients. Each of the $\mathrm{PIH}$ deaths were in patients with Paenibacillus.

Paenibacillus spp. abundance was inversely correlated with patient age, consistent with residua from neonatal infection (Fig. 4A, Fig. S6, Kruskal-Wallis, $\mathrm{P}<0.05$ ). Only PIH patients had high CSF cell counts $(>5 / \mu \mathrm{L})$; all were positive for Paenibacillus in the top abundance quartiles (Fig. 4B, Fig S6). Infants with hydrocephalus may have considerable extra weight in their heads from CSF relative to their body mass, and after calculating and subtracting excess fluid volumefor-age $(11,12)$, we found no difference between this corrected weight-for-age with hydrocephalus or Paenibacillus status (Fig. 4C). Seizures were more commonly reported in patients prior to admission ( 25 vs 13 ) and during hospital admission (9 vs 1 ) in patients who were Paenibacillus positive. The mean (SD) number of estimated days from initial febrile episode to when the head was noted to be growing was 21.4 (16.4) versus 29.3 (25.4) for Paenibacillus positive versus negative cases. Bloody CSF was noted in 15 CSF samples, but did not account for Paenibacillus positivity (1/7 positive in $\mathrm{PIH}$ ), or the presence of CMV in CSF (0/15 positive in $\mathrm{PIH}$ or NPIH).

Brain image CT scan scoring representative of brain abscesses, calcifications, loculations, and debris was calculated using preoperative imaging. PIH patients without measurable Paenibacillus had higher scores than NPIH patients, and PIH patients positive for Paenibacillus had significantly higher scores compared to PIH patients without Paenibacillus detected (Fig. 3B, 3C, Table S5, Figures S1, S6 and S7). All of the CSF positive CMV patients were PIH patients (Table S6), and each had at least one of the four signs comprising the CT score: 6/7 fluid loculations, debris within fluid spaces, or ectopic calcification, and 5/7 abscess (Table S7). We fit an ordinal logistic regression model that included PIH vs NPIH status and Paenibacillus presence. Patients with $\mathrm{PIH}$ had increased proportional odds for high CT score, OR $(95 \% \mathrm{Cl})=11.66(4.29,33.94)$ as well as Paenibacillus presence, OR $(95 \% \mathrm{Cl})=7.6(3.06$, 19.88). Testing for CMV presence did not show increased proportional odds of high CT scan scores (Fig. 3D), OR $(95 \% \mathrm{Cl})=3.30(0.52,29.66)$, when controlling for hydrocephalus etiology and Paenibacillus presence.

Growth and characterization of Paenibacillus strain 
medRxiv preprint doi: https://doi.org/10.1101/2020.08.03.20167544; this version posted August 4, 2020. The copyright holder for this preprint (which was not certified by peer review) is the author/funder, who has granted medRxiv a license to display the preprint in perpetuity.

All rights reserved. No reuse allowed without permission.

From 600 initial cultures from fresh frozen CSF (Table S8), 12 isolates were recovered from 7 patients (Table S9). Two isolates of Paenibacillus were recovered from cultures using small volumes $(50 \mu \mathrm{l})$ of fresh frozen patient samples, and 1 from the blind culture of a lytic anaerobic bottle (BD BACTEC). These were identified as Paenibacillus spp. using MALDI-TOF (Table S9). Of the three inoculum recoveries, two grew from subculture or blind culture onto solid media, identifying them as facultative anaerobes, while the third was never successfully subcultured. Marker gene analysis of the three Paenibacillus isolates were identified as $P$. thiaminolyticus, P. amyloliticus, and Paenibacillus sp. (Fig. 5, Supplementary Methods: phylogenetic tree placement). The 16S rRNA genes from the whole genome sequences of all 3 isolates were compared to the $16 \mathrm{~S}$ amplicon V1-V2 OTU cluster representative sequences. The $P$. thiaminolyticus isolate was most similar to that of OTU 99373, the most dominant OTU annotated as Paenibacillus within Paenibacillus-positive patients (Fig. S5). This identified the $P$. thiaminolyticus strain (hereafter, strain Mbale) as our isolate of interest for the subsequent tests for virulence in mice. Further, we compared this strain by $16 \mathrm{~S}$ rRNA gene similarity, average nucleotide identity (ANI) (http://enve-omics.ce.gatech.edu/ani/) (13), and biochemical testing against the $P$. thiaminolyticus type strain NRRL B-4156 ${ }^{\top}$ (=JCM $8360^{\top}$, GenBank accession CP041405). The 16S rRNA genes of this isolate had $99.2 \%-99.4 \%$ identity, and the wholegenome average nucleotide identity (gANI) value was $97.06 \%$, well above the $94-96 \%$ species threshold (14). Biochemical testing (https://apiweb.biomerieux.com, Table S10) had a 99.5$99.9 \%$ identity confirming that this isolate belongs to $P$. thiaminolyticus $(15,16)$. Antibiotic sensitivity was tested and the Mbale strain was broadly sensitive to common antibiotics (Table S11).

Thiamine testing

We tested for thiamine deficiency assaying for thiamine diphosphate (TDP) levels in whole blood. PIH cases (positive and negative for Paenibacillus) had lower TDP blood levels than NPIH cases (Fig. 3E, t-test, $p<0.05$ ).

\section{Pathogenicity of Paenibacillus strain Mbale}

Comparative virulence was assessed between the reference strain NRRL B-4156 and the strain Mbale in age-matched C57BL/6J mouse littermates of both sexes inoculated intraperitoneally at postnatal days $21-28$. The reference strain demonstrated no adverse effects on the mice, while the strain Mbale produced illness in all mice (16/16), with mortality or moribund states in 15/16 (93\%) of animals inoculated at a comparable concentration of colony forming units (Fig. 6, Table S12). The Mbale strain produced acute tubular necrosis in the kidneys, bone marrow myeloid hyperplasia, and moderate lymphocyte apoptosis in the splenic periarteriolar sheaths, but there were no significant brain lesions (Fig. 6). 
medRxiv preprint doi: https://doi.org/10.1101/2020.08.03.20167544; this version posted August 4, 2020. The copyright holder for this preprint (which was not certified by peer review) is the author/funder, who has granted medRxiv a license to display the preprint in perpetuity.

All rights reserved. No reuse allowed without permission.

\section{Discussion}

Postinfectious hydrocephalus may be the largest single cause of childhood hydrocephalus and the need for neurological surgery in children worldwide. These cases are concentrated in low- and middle-income countries (1), and the dominant predisposing event is often neonatal sepsis. Although such hydrocephalus is in principle preventable, the microbial spectrum that accounts for this disease, and the routes of infection, have never been well characterized.

We have therefore taken a very broad view to this disease, proposing that an unbiased identification of pathogens may be necessary to identify potential causal factors in developing world settings, drawn from the neonatal septisome (17) - the assemblage of the pathogens underlying neonatal sepsis in such settings.

Postinfectious hydrocephalus is part of a spectrum of conditions that through activation of the immune system in the brain lead to acquired hydrocephalus. The other major component of post-inflammatory hydrocephalus of infancy is intracerebral hemorrhage of prematurity. Both infection and hemorrhage within the brain lead to hydrocephalus through related inflammatory mechanisms (18). PIH is not a disease caused by a single organism, and the use of an unbiased pan-microbial analysis in other regions will likely reveal other organisms as important causes of PIH.One of the problems with utilizing genomic techniques for pathogen detection from nominally sterile body fluids, such as blood and CSF, is that such low-biomass samples are plagued by bacterial DNA contamination from reagents and other sources that can dominate the results (19), and substantial effort has addressed both statistical (20) and spike-in strategies (21) to reduce such effects. By employing case-controls in our study consisting of contemporaneously recruited NPIH patients referred to the same hospital, we were able to rigorously contrast our analysis of infected samples to that of clinically uninfected controls. By replicating our bacterial discovery efforts on differently preserved samples, in independent laboratories with separate regions of $16 \mathrm{~S}$, we reproduced convergent results - demonstrating a dominant Paenibacillus PIH pathogen in this cohort.

Whether prior analysis of postinfectious hydrocephalus in this region was biased by reagent contamination is not known at this time (7), but we implemented several technical strategies to reduce the effect of background contamination (see Supplementary Material). Despite such contamination reduction efforts, the additional use of case-controls was critical to achieve convincing levels of differential abundance significance, along with validation through organism recovery in culture from cases. The organism culture recovery rate was low, potentially due to the use of fresh frozen samples and antibiotic administration prior to patient sampling.

While various Paenibacillus spp. have been occasionally isolated from CSF (22-24), $P$. thiaminolyticus has not been known to be a virulent pathogen. It was first identified while screening for bacteria in the gut that might contribute to thiamine deficiency in beriberi in Asia (25). There is a single case report of indwelling catheter-associated bacteremia in an elderly patient on hemodialysis (26). This bacterium produces thiaminase I and II and is adapted to live in low-thiamine environments. Thiamine deficiency is associated with Wernicke's encephalopathy (27), two forms of beriberi (28), and polioencephalomalacia-associated brain necrosis in ruminant animals (29). In the developing world, thiamine deficiency is common in children (30), and is exacerbated by the stress of infection (31). Our findings demonstrate that thiamine levels were lower in postinfectious children regardless of infectious etiology, but, consistent with reports in animals (32), we did not demonstrate lower thiamine levels specifically due to infection with $P$. thiaminolyticus.

The underpinnings of the organism's virulence remain uncharacterized at present. We found it difficult to culture this facultatively anaerobic organism from clinical samples. Once established in culture, the organism could be passaged onto aerobic media. We speculate that 
medRxiv preprint doi: https://doi.org/10.1101/2020.08.03.20167544; this version posted August 4, 2020. The copyright holder for this preprint (which was not certified by peer review) is the author/funder, who has granted medRxiv a license to display the preprint in perpetuity.

All rights reserved. No reuse allowed without permission.

with a predilection to form calcified loculations and abscesses within the brain, it may be growing anaerobically when sampled, and require initial anaerobic conditions before switching to aerobic metabolism. Alternatively, the lytic properties of the anaerobic broth used successfully in recovery might have released viable organisms from intracellular phagocytosis within white blood cells. In either case, this organism has acquired substantial virulence in comparison with the existing reference strain, as demonstrated by nearly complete lethality of high concentrations of this organism when inoculated into mice in contrast with the reference strain. Supporting this differential virulence are multiple phage insertions into its genome, and other protein coding and copy number variations, that await further characterization.

The expression of differential virulence found in mice was constrained by the rapid lethality. The apparent toxin effect may have precluded replicating the establishment of the brain infections during sepsis which are the hallmark of $\mathrm{PIH}$. Although our findings and animal model do not meet Koch's postulates for disease causation (33), many infectious disease do not meet these criteria (34), and in particular PIH can be caused by different organisms. Nevertheless, $P$ thiaminolyticus Mbale was the dominant organism present in these $\mathrm{PIH}$ cases, correlation with disease severity on brain imaging was substantial, and correlation with central and peripheral WBC counts was strong.

Although this organism appears quite sensitive to common antibiotics, the presence of calcified abscesses will make the penetration of antibiotics to achieve adequate bactericidal concentrations challenging. Ideally, such concentrations are achieved at initial point-of-care treatment for neonatal sepsis prior to infection of the brain. It is possible that within the immuneprivileged brain (35), inadequate treatment during neonatal sepsis is a substantial factor in the persistent development of brain $P$. thiaminolyticus infection. How co-infection with CMV might affect disease severity in the setting of $P$. thiaminolyticus Mbale infection is unknown at this time.

The typical clinical picture of these PIH cases is that of a ventriculitis without prior meningitis. Whether lumbar puncture in such infants, without meningeal infection, could be diagnostic during their neonatal sepsis evaluation is presently unknown.

Notwithstanding that we find CSF purulence, high levels of matching DNA, and recovered organisms whose DNA matches that in infected cases closely, a full description of causality in this disease may be more complex. Our analysis was limited to detection of active infections. For the regions in which we were working, in utero exposure to infections such as malaria is common (36). But predisposing in utero infections which are no longer active after birth (whether parasitic, viral, or bacterial), would remain undetected in our genomic sampling. Our finding of a substantial viral background infection with CMV cannot distinguish congenital from postnatally acquired viral infection, but the true incidence of in utero infections must have been higher than what we could observe through testing several months after birth. In addition, our analysis does not address the heterogeneity in innate immunity (37) or nutritional status (38) known to be predisposing factors of infection.

The demographics of the Paenibacillus infections suggests localization to a circumscribed region in Eastern Uganda. This is a region associated with the north and south banks of Lake Kyoga, and the wetlands along the northern edge of Lake Victoria. It is characterized by large swamps and is a rice-growing region. Whether these infections are influenced by rainfall (39), which has been previously observed in $\mathrm{PIH}$ without organism identification (40), or share similarities with other environmental agents in similar topographies of the developing world (41), remains unknown.

Nevertheless, a pan-microbial approach has uncovered the presence of a difficult to grow pathogen not previously known to possess substantial virulence, which appears associated with calcified loculations and brain abscesses in infants, as well as with hydrocephalus following survival from neonatal sepsis. The presence of this organism upon a neurotropic viral background creates a scenario with frequent viral-bacterial coinfections where 
medRxiv preprint doi: https://doi.org/10.1101/2020.08.03.20167544; this version posted August 4, 2020. The copyright holder for this preprint (which was not certified by peer review) is the author/funder, who has granted medRxiv a license to display the preprint in perpetuity.

All rights reserved. No reuse allowed without permission.

6/8 CMV by CSF and 11/27 CMV by blood positive cases were co-infected with Paenibacillus spp. Prior studies in Ugandan adults have found that CMV viremia is frequently present in the setting of sepsis and is associated with increased risk of mortality (42-44). It has been hypothesized that immune modulation (45), rather than direct CMV effects, are responsible for the association of CMV with worse outcomes, especially for tuberculosis and cryptococcal meningitis. It is likely that, in many of these cases, latent CMV reactivates when overwhelming infection by another pathogen alters the immune system's ability to keep the virus sequestered $(44,45)$. However, due to the ages of our patients, all $<90$ days of age, a majority of the CMV viremias detected would be expected to be related to primary CMV infection (acquired either congenitally or during early postnatal life) and be more likely to cause, rather than be a cause of, alterations in immune function with related increases in bacterial pathogenesis and increased risk of severe bacterial infection (46).

Limitations to this study are important to note. PIH is a syndrome, and although we have identified a novel agent that appears to play a major role in the cases from Eastern Uganda, it remains unclear what other bacterial pathogens may play an important role in other regions of Uganda, or other countries within sub-Saharan Africa and beyond. Whether Paenibacilus spp. predisposes to invasion of the nervous system by CMV, or vice versa, remains unknown at present. The non-diagnostic PIH cases are mysteries, in that the ectopic calcifications seen commonly in the Paenibacillus positive cases would not have disappeared in the slightly older cohort of non-diagnostic patients - it is possible that they may have harbored different organisms. The prime limitation to our pan-microbial molecular approach seems to have been the age of the patients - only survivors of neonatal sepsis can develop $\mathrm{PIH}$, and our data is consistent with a need to identify the causative organisms as early as possible, ideally during treatment of neonatal sepsis accompanied by serial brain imaging.

Addressing the estimated 160,000 annual cases of PIH generated largely throughout the developing world (1), and the larger pool of several million yearly neonatal sepsis cases (2), is a critical global public health need. If a pan-microbial approach is required, then the current technology available to achieve this is at present neither readily scalable nor economically sustainable. On the other hand, the expansion of high-technology surgical facilities and pediatric neurosurgical care is also not readily scalable (47). Long-term, more sustainable and less expensive technologies to achieve pan-microbial surveillance in such settings, including maternal and environmental sources of infection, will be required to enable more optimal treatment and ultimately prevention of these devastating neonatal infections. 
medRxiv preprint doi: https://doi.org/10.1101/2020.08.03.20167544; this version posted August 4, 2020. The copyright holder for this preprint (which was not certified by peer review) is the author/funder, who has granted medRxiv a license to display the preprint in perpetuity.

All rights reserved. No reuse allowed without permission.

\section{Methods}

Study design and oversight. The study was conducted at the CURE Children's Hospital of Uganda (CCHU), a freestanding pediatric neurosurgical hospital in eastern Uganda that serves as a countrywide referral center for patients with hydrocephalus. Infants were eligible for participation in the trial if they were 3 months of age or younger, met criteria for postinfectious or non-postinfectious hydrocephalus (PIH and NPIH respectively), and had a mother who was at least 18 years of age. The study was designed as a waste-fluid study at surgery with verbal consent. Ethics oversight was provided by the CCHU Institutional Review Board, the Mbarara University of Science and Technology Research Ethics Committee, and with oversight of the Ugandan National Council on Science and Technology. The study was approved by the Penn State University Institutional Review Board, and a Materials Transfer Agreement was in place between CCHU and Penn State University. A US Centers for Disease Control permit for the importation of infectious materials covered the transfer of specimens from CCHU to Penn State. An Institutional Biosafety Committee provided oversight of specimen handling at Penn State. A Materials Transfer Agreement between Penn State and Columbia University covered the transport of materials between these research sites.

Inclusion criteria for $\mathrm{PIH}$ : a) age 3 months or less, b) weight greater than $2.5 \mathrm{Kg}, \mathrm{c}$ ) no history consistent with hydrocephalus at birth, and either i) a history of febrile illness and/or seizures preceding the onset of clinically apparent hydrocephalus, or ii) alternative findings such as imaging and endoscopic results indicative of prior ventriculitis including septations, loculations, or deposits of debris within the ventricular system (3), and d) mothers at least 18 years old to give informed consent.

Inclusion criteria for NPIH: a) age 3 months or less, b) weight greater than $2.5 \mathrm{Kg}, \mathrm{c}$ ) findings of non-infectious origin of hydrocephalus on computed tomography (CT) scan or at endoscopy such as a lesion obstructing the Aqueduct of Sylvius such as tumor or cyst, aneurysm, or cavernous malformation, Dandy-Walker cyst, or other congenital malformation of the nervous system, or d) evidence of hemorrhage as cause of hydrocephalus such as i) bloody CSF and ii) absence of findings consistent with PIH or congenital origin of hydrocephalus, and e) mothers at least 18 years old to give informed consent.

Exclusion criteria for hydrocephalus study: a) prior surgery on the nervous system (shunt, third ventriculostomy, or myelomeningocele closure), or b) evidence of communication of nervous system with skin such as meningocele, encephalocele, dermal sinus tract, or fistula.

Statistical Methods. Continuous demographic variables were evaluated using the nonparametric Wilcoxon rank-sum (two-group comparisons) and Kruskal-Wallis (>2 groups) tests following Shapiro-Wilk's test for normality, unless otherwise stated. Fisher's exact test was performed for categorical variables. All tests were two sided unless stated otherwise. Ordinal logistic regression was applied to estimate the proportional odds of CT scan scores between indication, Paenibacillus presence or absence, and CMV status. We performed differential abundance analysis of taxa abundances between PIH and NPIH groups and accounted for multiple testing leveraging false discovery rate analysis (48).

Brain image evaluation. Preoperative CT scans were independently scored, blindly with respect to diagnosis, by two board certified neurosurgeons who have considerable experience with infant hydrocephalus (BCW, SJS). One point was assigned for each of four possible findings: fluid loculations, debris within fluid spaces, ectopic calcification within the brain parenchyma, and abscess formation. Discrepancies between scoring were then resolved to a consensus agreement.

Sample collection and storage. Blood was sampled with aseptic technique at the time of surgery, either at the time of catheter placement for an intravenous line or during venipuncture for routine laboratory testing. CSF was obtained at the time of initial surgery. Many of the PIH cases were treated for abscess formation once or twice, prior to a definitive surgical procedure 
medRxiv preprint doi: https://doi.org/10.1101/2020.08.03.20167544; this version posted August 4, 2020. The copyright holder for this preprint (which was not certified by peer review) is the author/funder, who has granted medRxiv a license to display the preprint in perpetuity.

All rights reserved. No reuse allowed without permission.

to address the hydrocephalus (endoscopic third ventriculostomy with choroid plexus cauterization, or ventriculoperitoneal shunt insertion). Initial surgery might not employ an endoscope if the primary goal was aspiration and irrigation of purulent material from loculated fluid collections or frank abscesses. These initial procedures might also include endoscopic lateral terminalis and septum pellucidum fenestrations. The endoscope was nearly universally used in all other cases, such as NPIH, as is our standard practice at this surgical site. Samples of blood and spinal fluid were divided into aliquots for fresh freezing or placement into DNA/RNA preservative (DNA/RNA Shield, Zymo Corporation), and specimens were frozen either at $-80^{\circ} \mathrm{C}$ or placed in a liquid nitrogen Dewar or dry shipper. They were kept frozen through transport to the US for further analysis.

Ribosomal RNA (rRNA) 16S gene sequencing. For characterization of bacterial species we performed $16 S$ rDNA amplicon sequencing. Separate CSF samples were sequenced at two different laboratories. Independent approaches were applied to limit background amplification of contaminants and decontaminate reagents (see Supplementary Materials). At one laboratory, $16 \mathrm{~S}$ amplicon sequencing of the V1-V4 region was performed on fresh frozen samples using Sanger sequencing. Further next generation amplicon metabarcode sequencing was performed on V4 for microbial background characterization, and Paenibacillus genus-specific qPCR for quantification was performed. At the other laboratory, a primer extension technique for $16 \mathrm{~S}$ amplicon next generation sequencing of the V1-V2 region on DNA/RNA preserved samples was performed. Utilizing results from these two laboratories, $16 \mathrm{~S}$ amplicon (regions V1-V2 and V4) reads sequenced from fresh frozen CSF and preservative samples were clustered at $97 \%$ similarity (49). For downstream analyses we accounted for sequencing variability using cumulative sum scaling normalized taxa abundances (50). A primer table is given in Table S1.

Targeted pathogen gene testing. Targeted polymerase chain reaction (PCR) was performed in an attempt to detect the presence of Zika virus, chikungunya virus, human papilloma virus, parvovirus B19, toxoplasmosis, trypanosomiasis, malaria, and fungi (Table S1).

Virus detection. A broad screen for viral presence was performed in two different ways: VirCapSeq oligomer concentration (10) and total RNA sequencing analysis. For the viruses that appeared abundant in either PIH or NPIH, PCR confirmation was performed.

Metabolites. Thiamine diphosphate was quantified in fresh frozen blood using highperformance liquid chromatography with tandem mass spectrometry (LC/MS/MS) at Mayo Clinic Laboratories.

Microbiology. In an attempt to culture the putative pathogen, 100 fresh frozen CSF samples were subjected to 6 different media outlined in Table S8. If colonies grew on solid media, gram stain and matrix-assisted laser desorption/ionization time-of-flight (MALDI-TOF) were performed to characterize the organism. For isolates identified as Paenibacillus, antibiotic sensitivity, biochemical testing, and whole genome sequencing were performed.

Genome assembly. A hybrid method was utilized to reconstruct the genome of a $P$. thiaminolyticus isolate, combining short read sequencing, optical mapping (Bionano Genomics), and nanopore long contiguous sequencing (MinION, Oxford Nanopore Technologies). From the resulting whole genome sequences and optical mapping assembly a hybrid scaffold was generated (Bionano Hybrid Scaffold v1025201). For P. amylolyticus and Paenibacillus spp. isolates, and reference type strain P. thiaminolyticus NRRL B-4156 (Agricultural Research Service Culture Collection https://nrrl.ncaur.usda.gov/cgibin/usda/prokaryote/report.html?nrrlcodes=B-4156), only short read and nanopore sequencing were utilized for assembly.

Animal model virulence testing. All animal experiments were performed with oversight by the Penn State Institutional Animal Care and Use Committee, and with Institutional Biosafety Committee approval at biosafety level 2 (BSL2). Virulence testing was performed on weanling P21-P28 C57BL/6J mice using up to $10^{9}$ colony forming units suspended in $100 \mu \mathrm{L}$ saline, or saline only, injected into the peritoneum. Bacteria for injection were thawed and subcultured 
medRxiv preprint doi: https://doi.org/10.1101/2020.08.03.20167544; this version posted August 4, 2020. The copyright holder for this preprint (which was not certified by peer review) is the author/funder, who has granted medRxiv a license to display the preprint in perpetuity.

All rights reserved. No reuse allowed without permission.

prior to each inoculation and quantified using standard colony forming unit methods (Supplementary Material). Animals were humanely euthanized with $\mathrm{CO}_{2}$ if they developed altered or depressed mentation, or lost more than $20 \%$ of their body weight. A full complement of tissues were collected from each mouse following the guidelines set forth by international veterinary toxicology interest groups (51-53). Tissues were preserved in $10 \%$ neutral buffered formalin, embedded in paraffin blocks, cut into $3 \mu \mathrm{m}$ sections, and stained with hematoxylin and eosin for analysis. All organs were evaluated by a veterinary pathologist (HA). 
medRxiv preprint doi: https://doi.org/10.1101/2020.08.03.20167544; this version posted August 4, 2020. The copyright holder for this preprint (which was not certified by peer review) is the author/funder, who has granted medRxiv a license to display the preprint in perpetuity.

All rights reserved. No reuse allowed without permission.

\section{Acknowledgments}

We are grateful for the discussions and support of N. D. Olson, A. Patterson, Q. Liu, M. Mwebingwa, M. Poss, V. Kapur, D. Craft, and the technical assistance of K. Moran. Funding: Supported by NIH Director's Pioneer Award 1DP1HD086071 and NIH Director's Transformative Award 1R01Al145057. JEE was supported by National Center for Advancing Translational Sciences KL2 TR002015. MYG was supported by the NIH Intramural Research Program at the National Library of Medicine. ADW received salary support by an in-kind contribution from the University of Liverpool. Author contributions: The study was designed by J.K., and S.J.S. The manuscript was written by J.N.P, B.L.W., C.H., and S.J.S. The data analysis was performed by J.N.P., B.L.W., C.H., N.M., L.Z., S.M.K., M.P. Bacteriology was carried out by D.S.S.W., B.V.B., and J.B., and advised by M.Y.G. and M.A. Virology was performed by N.M. Wet lab technical analysis was performed by C.H., M.C-R., C.G., and J.N. Animal experiments were carried out by P.S., and histology performed by H.A. Independent laboratories were supervised by W.I.L. and J.B. Clinical work was performed by J.M., F.B., E.M-K., R.M., E.K., J.M., P.O-O., J.O., K.B., P.S. Project management was performed by S.S., E.M-K., J.K., E.K., K.S., A.D.W., M.G., T.W., W.I.L, J.B., and S.J.S. Bioinformatics was performed by J.N.P., L.Z., F.R., and J.Q.

Neurosurgical consultation was performed by A.V.K., D.D.L., B.C.W., and S.J.S. Infectious disease consultation was provided by L.B. and J.E.E. Computer support by B.N.K. Immunology consultation was performed by S.U.M. and M.H. CSF proteomics was performed by A.M.I., R.T., and D.D.L. Statistical analysis was provided by J.N.P., M.H., and X.L., and geographical mapping performed by A.J.W. and P.S. All authors contributed to editing the manuscript. Competing interests: None. Data and materials availability: The assembled genome of Paenibacillus thiaminolyticus Mbale was deposited in GenBank with Accession CP041404. Sequencing data for bacterial 16S DNA, in silico host-depleted mRNA, and VirCapSeq data, along with sample metadata are available at the NCBI archive under project ID PRJNA605220. There was a Materials Transfer Agreement between the provider CURE Children's Hospital of Uganda and recipient Penn State University, where Penn State University retains rights to the derivatives, Paenibacillus thiaminolyticus Mbale and for the Mbarara University of Science and Technology, CURE Children's Hospital of Uganda, and Penn State University to own any new products discovered through the use of the materials, Paenibacillus thiaminolyticus Mbale. There was a Materials Transfer Agreement between the provider Penn State University and recipient Columbia University, for Penn State University to retain ownership of the materials, Paenibacillus thiaminolyticus Mbale, and joint ownership of modifications. All custom code utilized in this study will be made available to investigators upon request. All data associated with this study are in the paper or supplementary materials.

List of the Supplementary Materials:

Materials and Methods

Figure S1: CT Scans.

Figure S2: Spatial Statistics.

Figure S3: Phylogenetic tree for $16 \mathrm{~S}$ V1-V4 sequences.

Figure S4: Further analysis of the microbial $16 \mathrm{~S}$ community.

Figure S5: OTU Heatmaps.

Figure S6: qPCR vs Age, CT Score, and Cell Counts.

Figure S7: CT Score Frequencies.

Table S1: Primer Table.

Table S2: Fresh Frozen PCR and Sequencing.

Table S3: Differential Abundance.

Table S4: Viral Results.

Table S5: Demographics with and without Paenibacillus. 
medRxiv preprint doi: https://doi.org/10.1101/2020.08.03.20167544; this version posted August 4, 2020. The copyright holder for this preprint (which was not certified by peer review) is the author/funder, who has granted medRxiv a license to display the preprint in perpetuity.

All rights reserved. No reuse allowed without permission.

Table S6: Paenibacillus vs CMV.

Table S7: CT Score vs CMV.

Table S8: Culture Media.

Table S9: Culture Results.

Table S10: Biochemical testing of P. thiaminolyticus.

Table S11: Antibiotic Resistance.

Table S12: Virulence Testing.

References (56-105) 


\section{References}

1. M. C. Dewan, A. Rattani, R. Mekary, L. J. Glancz, I. Yunusa, R. E. Baticulon, G. Fieggen, J. C. Wellons, 3rd, K. B. Park, B. C. Warf, Global hydrocephalus epidemiology and incidence: systematic review and meta-analysis. J Neurosurg, 1-15 (2018).

2. S. L. Ranjeva, B. C. Warf, S. J. Schiff, Economic burden of neonatal sepsis in subSaharan Africa. BMJ Glob Health 3, e000347 (2018).

3. B. C. Warf, Hydrocephalus in Uganda: the predominance of infectious origin and primary management with endoscopic third ventriculostomy. Journal of neurosurgery 102, 1-15 (2005).

4. B. C. Warf, B. C. Alkire, S. Bhai, C. Hughes, S. J. Schiff, J. R. Vincent, J. G. Meara, Costs and benefits of neurosurgical intervention for infant hydrocephalus in sub-Saharan Africa. Journal of neurosurgery Pediatrics 8, 509-521 (2011).

5. I. A. Aziz, Hydrocephalus in the Sudan. Journal of the Royal College of Surgeons of Edinburgh 21, 222-224 (1976).

6. L. C. Handler, M. G. Wright, Postmeningitic hydrocephalus in infancy. Ventriculography with special reference to ventricular septa. Neuroradiology 16, 31-35 (1978).

7. L. Li, A. Padhi, S. L. Ranjeva, S. C. Donaldson, B. C. Warf, J. Mugamba, D. Johnson, Z. Opio, B. Jayarao, V. Kapur, M. Poss, S. J. Schiff, Association of bacteria with hydrocephalus in Ugandan infants. J Neurosurg Pediatr 7, 73-87 (2011).

8. A. V. Kulkarni, S. J. Schiff, E. Mbabazi-Kabachelor, J. Mugamba, P. Ssenyonga, R. Donnelly, J. Levenbach, V. Monga, M. Peterson, M. MacDonald, V. Cherukuri, B. C. Warf, Endoscopic Treatment versus Shunting for Infant Hydrocephalus in Uganda. $N$ Engl J Med 377, 2456-2464 (2017).

9. R. Sinha, G. Abu-Ali, E. Vogtmann, A. A. Fodor, B. Ren, A. Amir, E. Schwager, J. Crabtree, S. Ma, C. Microbiome Quality Control Project, C. C. Abnet, R. Knight, O. White, C. Huttenhower, Assessment of variation in microbial community amplicon sequencing by the Microbiome Quality Control (MBQC) project consortium. Nat Biotechnol 35, 1077-1086 (2017).

10. T. Briese, A. Kapoor, N. Mishra, K. Jain, A. Kumar, O. J. Jabado, W. I. Lipkin, Virome Capture Sequencing Enables Sensitive Viral Diagnosis and Comprehensive Virome Analysis. mBio 6, e01491-01415 (2015).

11. M. Peterson, B. C. Warf, S. J. Schiff, Normative human brain volume growth. J Neurosurg Pediatr 21, 478-485 (2018).

12. J. G. Mandell, J. W. Langelaan, A. G. Webb, S. J. Schiff, Volumetric brain analysis in neurosurgery: Part 1. Particle filter segmentation of brain and cerebrospinal fluid growth dynamics from MRI and CT images. J Neurosurg Pediatr 15, 113-124 (2015).

13. R. L. Rodriguez, S. Gunturu, W. T. Harvey, R. Rossello-Mora, J. M. Tiedje, J. R. Cole, K. T. Konstantinidis, The Microbial Genomes Atlas (MiGA) webserver: taxonomic and gene diversity analysis of Archaea and Bacteria at the whole genome level. Nucleic Acids Res 46, W282-W288 (2018).

14. C. Hehnly, L. Lijun Zhang, J. Paulson, M. Almeida, B. von Bredow, D. S. S. Wijetunge, N. D. Olson, M. Galperin, K. Sheldon, S. J. Schiff, J. R. Broach, Complete Genome Sequences of the Human Pathogen P. thiaminolyticus Mbale and Type Strain P. thiaminolyticus NRRL B-4156. Microbiological Resource Announcements, (submitted).

15. K. T. Konstantinidis, J. M. Tiedje, Genomic insights that advance the species definition for prokaryotes. Proc Natl Acad Sci U S A 102, 2567-2572 (2005).

16. J. Goris, K. T. Konstantinidis, J. A. Klappenbach, T. Coenye, P. Vandamme, J. M. Tiedje, DNA-DNA hybridization values and their relationship to whole-genome sequence similarities. Int J Syst Evol Microbiol 57, 81-91 (2007). 
medRxiv preprint doi: https://doi.org/10.1101/2020.08.03.20167544; this version posted August 4, 2020. The copyright holder for this preprint (which was not certified by peer review) is the author/funder, who has granted medRxiv a license to display the preprint in perpetuity. All rights reserved. No reuse allowed without permission.

17. J. Kiwanuka, J. Bazira, J. Mwanga, D. Tumusiime, E. Nyesigire, N. Lwanga, B. C. Warf, V. Kapur, M. Poss, S. J. Schiff, The Microbial Spectrum of Neonatal Sepsis in Uganda: Recovery of Culturable Bacteria in Mother-Infant Pairs. PLoS ONE 8, e72775-e72775 (2013).

18. R. B. Karimy J, Damisah E, Duy P, Antwi P, David W, Wang K, Schiff S, Limbrick Jr. D, Alper S, Warf B, Nedergaard M, Simard J, and Kahle K., Pathogenic mechanisms and therapeutic targets of inflammation in acquired hydrocephalus. Nature Reviews Neurology, (2020 in press).

19. S. J. Salter, M. J. Cox, E. M. Turek, S. T. Calus, W. O. Cookson, M. F. Moffatt, P. Turner, J. Parkhill, N. J. Loman, A. W. Walker, Reagent and laboratory contamination can critically impact sequence-based microbiome analyses. BMC Biol 12, 87 (2014).

20. N. M. Davis, D. M. Proctor, S. P. Holmes, D. A. Relman, B. J. Callahan, Simple statistical identification and removal of contaminant sequences in marker-gene and metagenomics data. Microbiome 6, 226 (2018).

21. M. S. Zinter, M. Y. Mayday, K. K. Ryckman, L. L. Jelliffe-Pawlowski, J. L. DeRisi, Towards precision quantification of contamination in metagenomic sequencing experiments. Microbiome 7, (2019).

22. P. P. Bosshard, Paenibacillus turicensis sp. nov., a novel bacterium harbouring heterogeneities between 16S rRNA genes. International Journal of Systematic and Evolutionary Microbiology 52, 2241-2249 (2002).

23. S. D. DeLeon, R. C. Welliver, Sr., Paenibacillus alvei Sepsis in a Neonate. Pediatr Infect Dis J 35, 358 (2016).

24. V. Roux, L. Fenner, D. Raoult, Paenibacillus provencensis sp. nov., isolated from human cerebrospinal fluid, and Paenibacillus urinalis sp. nov., isolated from human urine. Int $J$ Syst Evol Microbiol 58, 682-687 (2008).

25. Y. Kuno, Bacillus Thiaminolyticus, a New Thiamin-Decomposing Bacterium. Imp. Acad. Jpn. Proc. 27, 362-365 (1951).

26. J. Ouyang, Z. Pei, L. Lutwick, S. Dalal, L. Yang, N. Cassai, K. Sandhu, B. Hanna, R. L. Wieczorek, M. Bluth, M. R. Pincus, Case report: Paenibacillus thiaminolyticus: a new cause of human infection, inducing bacteremia in a patient on hemodialysis. Ann Clin Lab Sci 38, 393-400 (2008).

27. N. Latt, G. Dore, Thiamine in the treatment of Wernicke encephalopathy in patients with alcohol use disorders. Intern Med J 44, 911-915 (2014).

28. D. Lonsdale, A review of the biochemistry, metabolism and clinical benefits of thiamin(e) and its derivatives. Evid Based Complement Alternat Med 3, 49-59 (2006).

29. K. E. Milad, G. S. Ridha, The occurrence of thiamine-responsive polioencephalomalacia in dromedary breeding camels in Libya: preliminary investigation of diagnosis. Iraqi Journal of Veterinary Sciences 23, suppl 1, 119-122 (2009).

30. D. Coats, K. Shelton-Dodge, K. Ou, V. Khun, S. Seab, K. Sok, C. Prou, S. Tortorelli, T. P. Moyer, L. E. Cooper, T. P. Begley, F. Enders, P. R. Fischer, M. Topazian, Thiamine deficiency in Cambodian infants with and without beriberi. J Pediatr 161, 843-847 (2012).

31. L. Hiffler, B. Rakotoambinina, N. Lafferty, D. Martinez Garcia, Thiamine Deficiency in Tropical Pediatrics: New Insights into a Neglected but Vital Metabolic Challenge. Front Nutr 3, 16 (2016).

32. C. A. Richter, A. N. Evans, M. K. Wright-Osment, J. L. Zajicek, S. A. Heppell, S. C. Riley, C. C. Krueger, D. E. Tillitt, K. Kidd, Paenibacillus thiaminolyticus is not the cause of thiamine deficiency impeding lake trout (Salvelinus namaycush) recruitment in the Great Lakes. Canadian Journal of Fisheries and Aquatic Sciences 69, 1056-1064 (2012).

33. R. Koch, An Address on Bacteriological Research. Br Med J 2, 380-383 (1890). 
34. D. N. Fredericks, D. A. Relman, Sequence-based identification of microbial pathogens: a reconsideration of Koch's postulates. Clinical Microbiology Reviews 9, 18-33 (1996).

35. A. Louveau, T. H. Harris, J. Kipnis, Revisiting the Mechanisms of CNS Immune Privilege. Trends Immunol 36, 569-577 (2015).

36. C. Menendez, A. Mayor, Congenital malaria: the least known consequence of malaria in pregnancy. Semin Fetal Neonatal Med 12, 207-213 (2007).

37. J. L. Casanova, Severe infectious diseases of childhood as monogenic inborn errors of immunity. Proc Natl Acad Sci U S A 112, E7128-7137 (2015).

38. N. J. Afacan, C. D. Fjell, R. E. Hancock, A systems biology approach to nutritional immunology - focus on innate immunity. Mol Aspects Med 33, 14-25 (2012).

39. S. J. Schiff, Neural Control Engineering: The Emerging Intersection Between Control Theory and Neuroscience. Computational neuroscience (MIT Press, 2012).

40. S. J. Schiff, S. L. Ranjeva, B. C. Warf, Rainfall drives hydrocephalus in East Africa. Journal of neurosurgery Pediatrics 10, 161-167 (2012).

41. W. J. Wiersinga, H. S. Virk, A. G. Torres, B. J. Currie, S. J. Peacock, D. A. B. Dance, D. Limmathurotsakul, Melioidosis. Nat Rev Dis Primers 4, 17107 (2018).

42. C. P. Skipper, M. R. Schleiss, A. S. Bangdiwala, N. Hernandez-Alvarado, K. Taseera, H. W. Nabeta, A. K. Musubire, S. M. Lofgren, D. L. Wiesner, J. Rhein, R. Rajasingham, C. Schutz, G. Meintjes, C. Muzoora, D. B. Meya, D. R. Boulware, C. Team, Cytomegalovirus viremia associated with increased mortality in cryptococcal meningitis in sub-Saharan Africa. Clin Infect Dis, ciz864 (2019).

43. C. C. Moore, S. T. Jacob, P. Banura, J. Zhang, S. Stroup, D. R. Boulware, W. M. Scheld, E. R. Houpt, J. Liu, Etiology of Sepsis in Uganda Using a Quantitative Polymerase Chain Reaction-based TaqMan Array Card. Clin Infect Dis 68, 266-272 (2019).

44. A. H. Walton, J. T. Muenzer, D. Rasche, J. S. Boomer, B. Sato, B. H. Brownstein, A. Pachot, T. L. Brooks, E. Deych, W. D. Shannon, J. M. Green, G. A. Storch, R. S. Hotchkiss, Reactivation of multiple viruses in patients with sepsis. PLoS One 9, e98819 (2014).

45. G. Monneret, F. Venet, Sepsis-induced immune alterations monitoring by flow cytometry as a promising tool for individualized therapy. Cytometry B Clin Cytom 90, 376-386 (2016).

46. W. G. Nichols, L. Corey, T. Gooley, C. Davis, M. Boeckh, High risk of death due to bacterial and fungal infection among cytomegalovirus (CMV)-seronegative recipients of stem cell transplants from seropositive donors: evidence for indirect effects of primary CMV infection. J Infect Dis 185, 273-282 (2002).

47. T. E. Chao, K. Sharma, M. Mandigo, L. Hagander, S. C. Resch, T. G. Weiser, J. G. Meara, Cost-effectiveness of surgery and its policy implications for global health: a systematic review and analysis. The Lancet Global Health 2, e334-e345 (2014).

48. Y. Benjamini, Y. Hochberg, Controlling the False Discovery Rate - a Practical and Powerful Approach to Multiple Testing. Journal of the Royal Statistical Society Series BMethodological 57, 289-300 (1995).

49. J. G. Caporaso, J. Kuczynski, J. Stombaugh, K. Bittinger, F. D. Bushman, E. K. Costello, N. Fierer, A. G. Pena, J. K. Goodrich, J. I. Gordon, G. A. Huttley, S. T. Kelley, D. Knights, J. E. Koenig, R. E. Ley, C. A. Lozupone, D. McDonald, B. D. Muegge, M. Pirrung, J. Reeder, J. R. Sevinsky, P. J. Turnbaugh, W. A. Walters, J. Widmann, T. Yatsunenko, J. Zaneveld, R. Knight, QIIME allows analysis of high-throughput community sequencing data. Nat Methods 7, 335-336 (2010).

50. J. N. Paulson, O. C. Stine, H. C. Bravo, M. Pop, Differential abundance analysis for microbial marker-gene surveys. Nat Methods 10, 1200-1202 (2013). 
medRxiv preprint doi: https://doi.org/10.1101/2020.08.03.20167544; this version posted August 4, 2020. The copyright holder for this preprint

(which was not certified by peer review) is the author/funder, who has granted medRxiv a license to display the preprint in perpetuity.

All rights reserved. No reuse allowed without permission.

51. C. Ruehl-Fehlert, B. Kittel, G. Morawietz, P. Deslex, C. Keenan, C. R. Mahrt, T. Nolte, M. Robinson, B. P. Stuart, U. Deschl, R. Group, N. Group, Revised guides for organ sampling and trimming in rats and mice--part 1. Exp Toxicol Pathol 55, 91-106 (2003).

52. B. Kittel, C. Ruehl-Fehlert, G. Morawietz, J. Klapwijk, M. R. Elwell, B. Lenz, M. G. O'Sullivan, D. R. Roth, P. F. Wadsworth, R. Group, N. Group, Revised guides for organ sampling and trimming in rats and mice--Part 2. A joint publication of the RITA and NACAD groups. Exp Toxicol Pathol 55, 413-431 (2004).

53. G. Morawietz, C. Ruehl-Fehlert, B. Kittel, A. Bube, K. Keane, S. Halm, A. Heuser, J. Hellmann, R. Group, N. Group, Revised guides for organ sampling and trimming in rats and mice--Part 3. A joint publication of the RITA and NACAD groups. Exp Toxicol Pathol 55, 433-449 (2004).

54. P. Ssentongo, A. J. B. Muwanguzi, U. Eden, T. Sauer, G. Bwanga, G. Kateregga, L. Aribo, M. Ojara, W. K. Mugerwa, S. J. Schiff, Changes in Ugandan Climate Rainfall at the Village and Forest Level. Scientific Reports 8, 3551 (2018).

55. C. Ash, F. G. Priest, M. D. Collins, Molecular identification of rRNA group 3 bacilli (Ash, Farrow, Wallbanks and Collins) using a PCR probe test. Proposal for the creation of a new genus Paenibacillus. Antonie Van Leeuwenhoek 64, 253-260 (1993). 
medRxiv preprint doi: https://doi.org/10.1101/2020.08.03.20167544; this version posted August 4, 2020. The copyright holder for this preprint (which was not certified by peer review) is the author/funder, who has granted medRxiv a license to display the preprint in perpetuity.

All rights reserved. No reuse allowed without permission.

\section{Figure Legends}

Figure 1. Comparative location of cases within map of Uganda. The village centroid GPS locations are mapped to the $0.1 \times 0.1$ degree grid frequently used in satellite rainfall estimation (54), and where village name was uncertain, the centroid of the administrative parish or subcounty was used. The groups shown are mapped by clinical status (NPIH and PIH), and by organism type (Paenibacillus, PAENI; cytomegalovirus, CMV). Both the PAENI and CMV mappings included all NPIH and PIH cases with such diagnoses. Using Fisher's linear discrimination analysis, group comparisons by latitude and longitude mapping could significantly discriminate NPIH from $\mathrm{PIH}$, or NPIH from PAENI, at the $p<0.01$ level parametrically (Wilk's lambda), and at the $p=0.03$ and $p=0.01$ level respectively using a bootstrap method (see Figure S2). The number of cases mapped to a $0.1 \times 0.1$ degree grid ( $11 \mathrm{~km}$ per edge at the equator) are indicated with colored circles as 1,2 , or 3.

Figure 2. Detection and typing of bacteria using 16S rDNA. A) Agarose gels showing $16 \mathrm{~S}$ rDNA amplification products for PIH (red) and NPIH (blue), along with PCR positive (+) and negative (-) controls (green) and 10 separate extraction reagent controls (yellow). Brightness and contrast were adjusted for gels to maximize visibility of faint bands and smears. Asterisk $\left(^{*}\right)$ denotes lanes where faint non-specific amplification (smears) or bands of unexpected size were observed. All amplification products including non-specific amplifications were subjected to subcloning and sequencing. B) Paenibacillus qPCR quantification. C-D) Stacked bar relative abundance plots of (C) 16S V4 and (D) V1-V2 regions in microbial communities for the most dominant bacteria observed within (C) 16S positive samples from (B) and in (D) all 100 samples. Star underneath $\mathrm{PIH}$ sample $(\mathrm{C}, \mathrm{D})$ highlights individual $\mathrm{PIH}$ sample with group $\mathrm{B}$ streptococcal infection. E) Scatterplot of cumulative sum scaling normalized Paenibacillus abundance for (abscissa) V4 16S sequencing of fresh frozen CSF samples and (ordinate) V1V2 $16 S$ sequencing of biological replicates from preserved CSF samples. F) Receiveroperating-characteristic (ROC) curve using the number of Paenibacillus reads as the predictor for PIH or NPIH status. Area under the curve was 70.88\% (95\% DeLong Cl $=60.61 \%-81.15 \%$ ). Sensitivity and specificity are maximized at 47.5 reads in a given sample, consistent with the threshold employed of 50 reads.

Figure 3. Viral detection, CT findings, thiamine levels, and infection status. A) Venn diagram of CMV detection using PCR on blood, and VirCap-Seq, RNA-Sequencing and PCR on CSF samples. B) Representative images of patients with NPIH or PIH, and CMV or Paenibacillus (Paeni) status. Both NPIH demonstrate Dandy-Walker cyst malformations ( $\mathbf{\Delta}$ ) without history or surgical findings reflective of prior infection. Note the presence in the Paenibacillus PIH cases of multiple loculations of CSF $(*)$, higher density fluid collections reflective of debris or blood within the CSF $(\boldsymbol{\nabla})$, ectopic calcification within the brain $(\square)$, and abscess formation (O). C) CT scores stratified by clinical indication, PIH or NPIH, and D) as a function of CMV and Paenibacillus infection status, positive or negative respectively (see also Fig S6). E) Levels, in $n$ mol/L, of thiamine diphosphate (TDP) in PIH $(n=42)$ vs NPIH $(n=19)$ cases. We observed that TDP levels are lower in PIH patients, (t-test, $p<0.05$ ). Boxplots display the median and upper and lower quartiles with whiskers forming the $1.5 \mathrm{x}$ the interquartile range.

Figure 4. Clinical signs associate with Paenibacillus detection. A) Boxplots of (ordinate) log2 normalized Paenibacillus 16S rDNA abundance by age (categorized into 0-6 weeks and $>6$ weeks) and by indication (see also Fig S6). B) Boxplots of (ordinate) CSF WBC count (cell/ $\mu \mathrm{L})$ by Paenibacillus status (+/-) and by indication (see also Fig S6). Cell count values less than 5 
medRxiv preprint doi: https://doi.org/10.1101/2020.08.03.20167544; this version posted August 4, 2020. The copyright holder for this preprint (which was not certified by peer review) is the author/funder, who has granted medRxiv a license to display the preprint in perpetuity.

All rights reserved. No reuse allowed without permission.

were mapped to 5. Cell count values greater than 250 were mapped to 250. C) Boxplots of (ordinate) corrected weight-for-age z-scores (WAZ), after calculating and subtracting excess CSF volume-for-age, by Paenibacillus status (+/-) and by indication. Boxplots display the median and upper and lower quartiles with whiskers forming the $1.5 x$ the interquartile range.

Figure 5. Whole genome sequencing and assembly of $P$. thiaminolyticus CSF isolate strain Mbale. From the cultured CSF samples, three isolates were identified as Paenibacillus (marked with asterisks in panel $\mathrm{C}$ ). One isolate showed high $16 \mathrm{~S}$ rDNA sequence identity to our V1-V2 and V4 sequencing results thus making it the isolate of high interest. A) $P$. thiaminolyticus Mbale Gram stain from the chocolate agar subculture of the lytic anaerobic bottle at 1,000x magnification. Weak or negative Gram staining, despite a Gram positive cell structure, is characteristic of Paenibacillus species (55). B) To classify the $P$. thiaminolyticus clinical isolate, an extensive genome analysis was performed using both long-read and next generation sequencing along with optical mapping (GenBank Accession CP041404). The resulting draft circular genome shown was created using CGView which features coding sequences (CDS), tRNA, rRNA, phage insertions and GC content (53\%). C) Phylogenetic tree of Paenibacillus spp. based on 40 marker genes. Cultured CSF isolates are indicated by yellow marks; the isolate 2033 was renamed $P$. thiaminolyticus strain Mbale.

Figure 6. Comparative murine histology of reference and Mbale strains of Paenibacillus thiaminolyticus. Murine model contrasting the virulence of the Mbale strain of $P$. thiaminolyticus vs the reference $P$. thiaminolyticus type strain NRRL B- $4156^{\top}$ following intraperitoneal injection into C56BL/6J littermates, in comparison with saline control injections. No significant lesions are seen (top row) in the spleen of mice inoculated with normal saline $(n=6)$ or reference strain $(n=10)$. However, tingible body macrophage necrosis (black arrows) with intracytoplasmic apoptotic bodies were present in spleen of mice inoculated with the Mbale strain (9/10), suggestive of toxin induced apoptosis and a marked immune response with a high lymphocyte turnover. Likewise, the kidneys (middle row) of mice inoculated with normal saline or the reference strain had no significant lesions. In contrast, pyknotic nuclei (arrow head) of proximal tubule epithelial cells with cell sloughing and loss were observed within mice inoculated with the Mbale strain (9/10), indicative of acute tubular necrosis. In the brain (bottom row), there was no substantial evidence of infection-associated pathology (normal saline $n=6 / 6$, reference strain $n=10 / 10$, Mbale strain $n=10 / 10$ ). 
medRxiv preprint doi: https://doi.org/10.1101/2020.08.03.20167544; this version posted August 4, 2020. The copyright holder for this preprint (which was not certified by peer review) is the author/funder, who has granted medRxiv a license to display the preprint in perpetuity.

All rights reserved. No reuse allowed without permission.

Tables

Table 1: Demographics and clinical characteristics of NPIH and PIH cohort.

\begin{tabular}{|c|c|c|c|}
\hline Characteristics & $\begin{array}{l}\text { All patients } \\
n=100\end{array}$ & $\begin{array}{c}\text { PIH } \\
n=64\end{array}$ & $\begin{array}{l}\text { NPIH } \\
n=36\end{array}$ \\
\hline Age in days, mean (SD) & $57(24)$ & $66(17)$ & $43(27)$ \\
\hline \multicolumn{4}{|l|}{ Sex } \\
\hline Male (\%) & $51(51)$ & $35(55)$ & $16(44)$ \\
\hline Female (\%) & $49(49)$ & $29(45)$ & $20(56)$ \\
\hline $\begin{array}{l}\text { Peripheral blood WBC } \\
{\left[1.0 \times 10^{3}\right] / \mu \mathrm{L} \text {, mean (SD) }}\end{array}$ & $10.3(3.6)$ & $11.0(3.8)$ & $8.8(2.6)$ \\
\hline 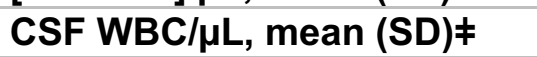 & $30(62)$ & $45(74)$ & $5(0.5)$ \\
\hline Hemoglobin g/dl, mean (SD) & $11.5(2.2)$ & $10.7(1.3)$ & $13.0(2.8)$ \\
\hline Hematocrit \%, mean (SD) & $36.8(7.4)$ & $34.1(4.1)$ & $41.6(9.3)$ \\
\hline \multicolumn{4}{|l|}{$\begin{array}{l}\text { CT scan scoring* } \\
\text { [no. and \% in each category] }\end{array}$} \\
\hline 0 & $32(33)$ & $8(25)$ & $24(69)$ \\
\hline 1 & $15(15)$ & $7(11)$ & $8(23)$ \\
\hline 2 & $13(13)$ & $10(16)$ & $3(8)$ \\
\hline 3 & $11(11)$ & $11(17)$ & $0(0)$ \\
\hline 4 & $27(28)$ & $27(43)$ & $0(0)$ \\
\hline \multicolumn{4}{|l|}{ HIV Exposure status [no. and \%] } \\
\hline Yes & $5(5)$ & $3(5)$ & $2(6)$ \\
\hline No & $95(95)$ & $61(95)$ & $34(94)$ \\
\hline
\end{tabular}

Patient demographics and Clinical Characteristics. Comparison of demographic and clinical attributes between two groups: Postinfectious hydrocephalus $(\mathrm{PIH}, \mathrm{n}=64)$ and nonpostinfectious hydrocephalus (NPIH, n=36). PIH patients were older (66 days vs 43 days, $p$ $<0.0001$ ), had higher peripheral and cerebrospinal fluid (CSF) white blood cell (WBC) counts, and were more likely to be anemic (hemoglobin $10.7 \mathrm{~g} / \mathrm{dL}$ vs $13.0 \mathrm{~g} / \mathrm{dL}, \mathrm{p}<0.0001$ ) compared with NPIH patients. Preoperative computed tomography (CT) scans were available for 98 subjects. Of these, the PIH group was more likely to have a higher CT scan score reflective of brain abscess, calcifications, loculations and septations $(p<0.0001)$. There were no significant differences in gender and human immunodeficiency virus (HIV) exposure frequencies between the groups. Continuous demographic variables were evaluated using the non-parametric Wilcoxon rank-sum (2-group comparisons) and Kruskal-Wallis ( $>2$ groups) tests following Shapiro-Wilk's test for normality unless otherwise stated. Fisher's exact test was performed for categorical variables. 
Figure 1

*
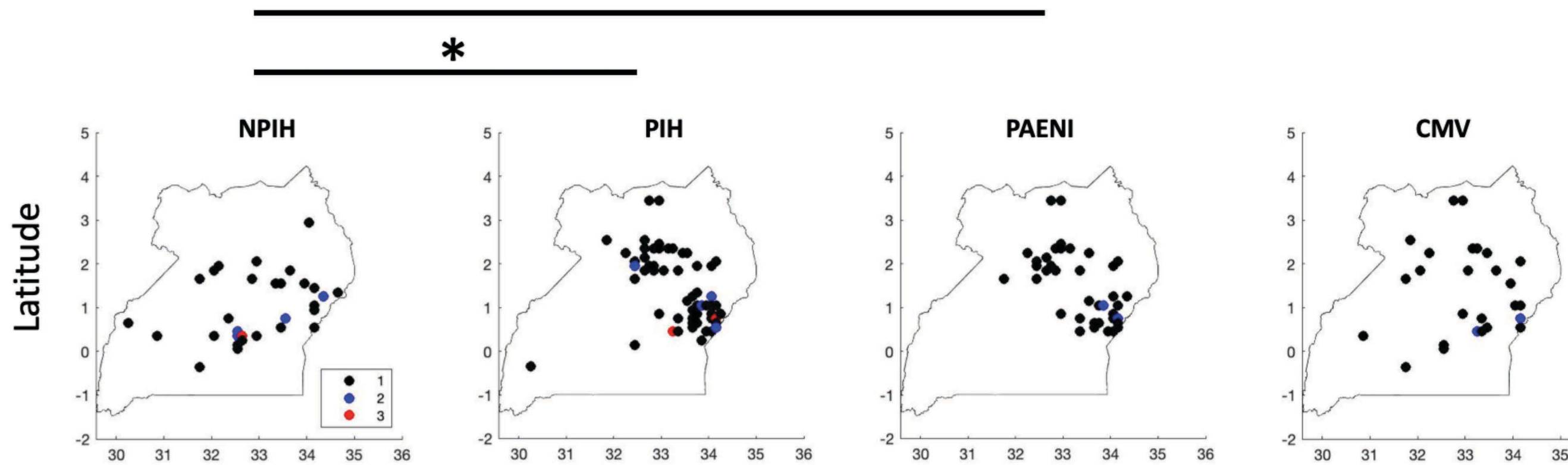

Longitude 


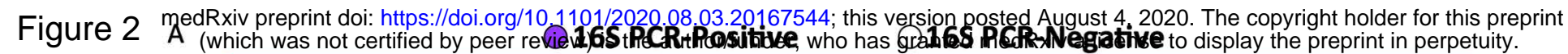

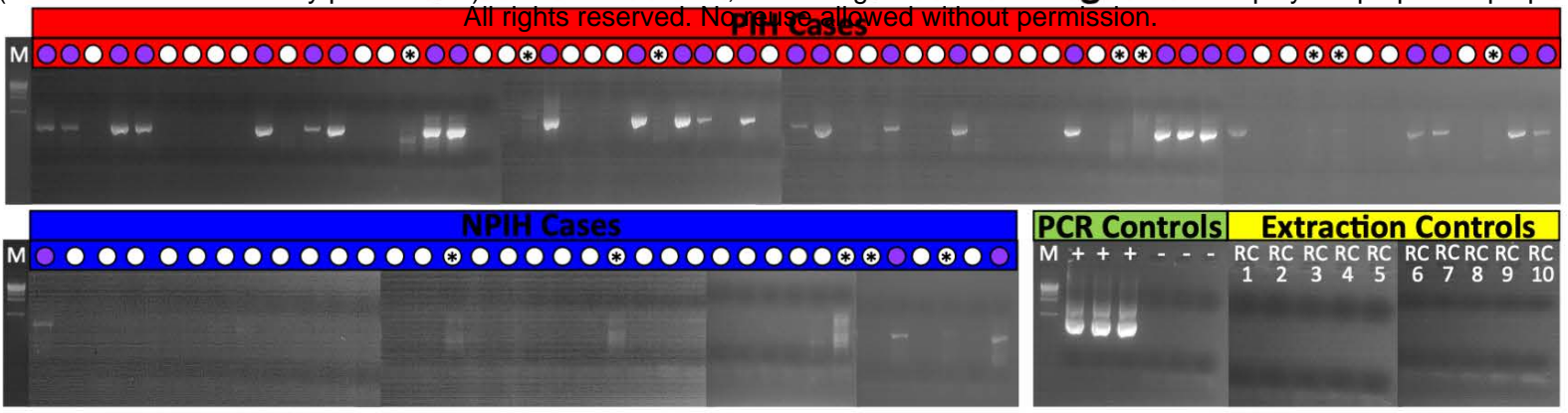

B

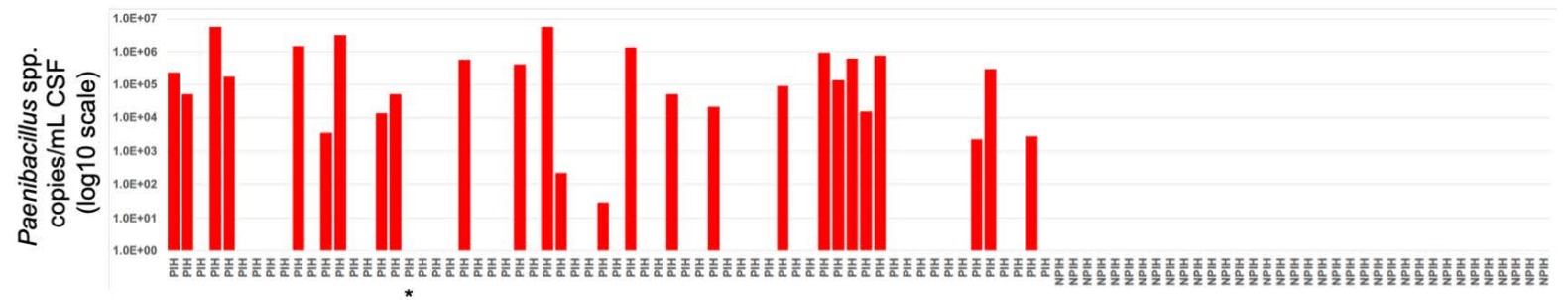

C
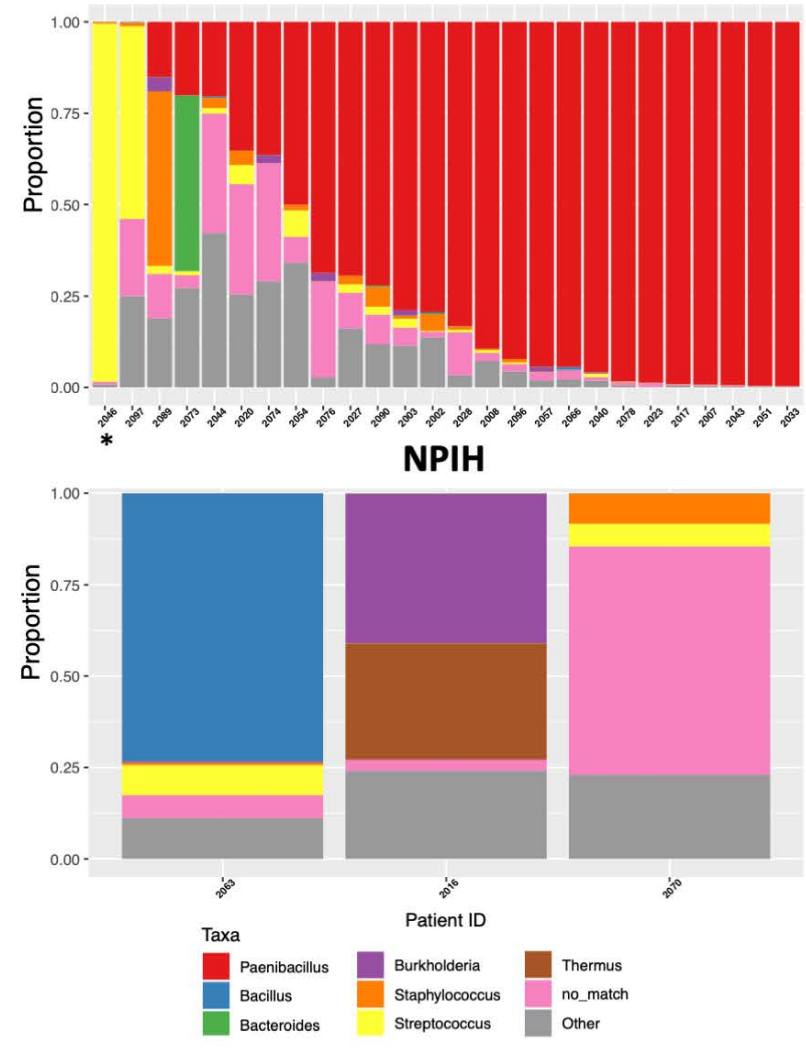

E

Paenibacillus spp. abundance by $16 \mathrm{~S}$ region

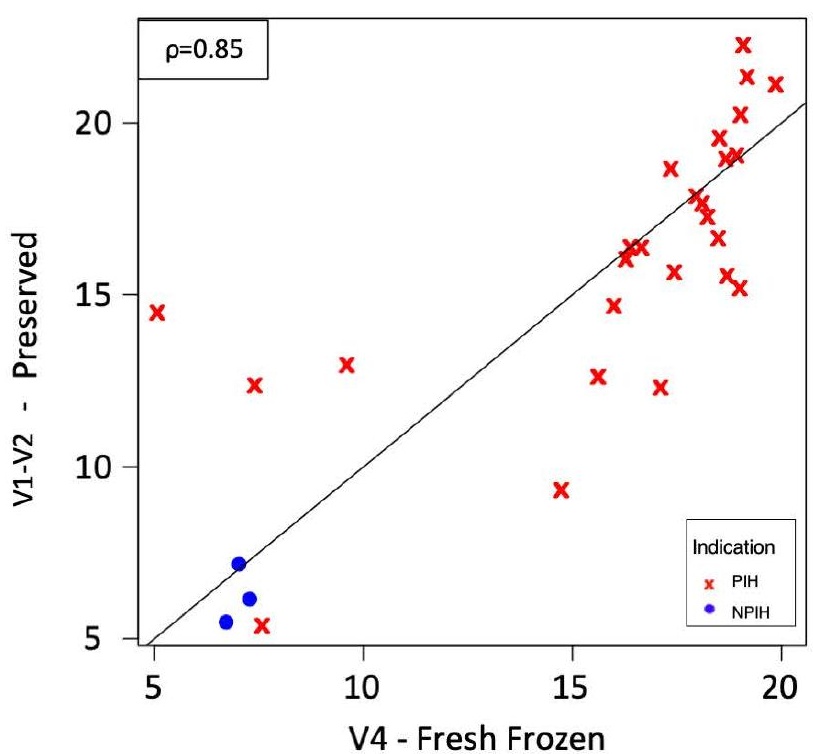

PIH

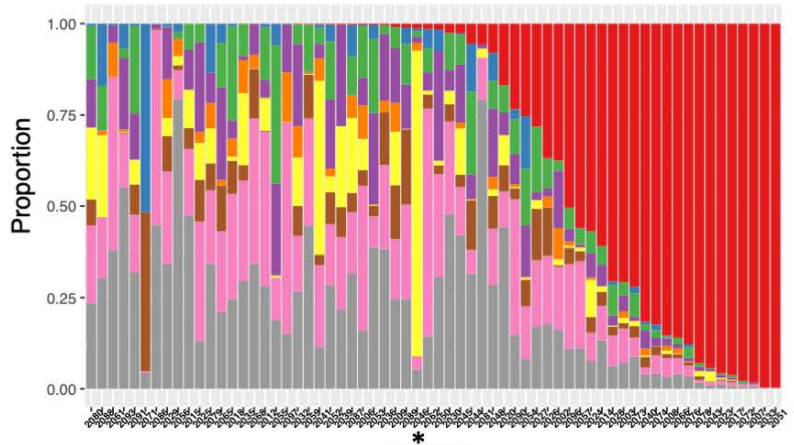

NPIH

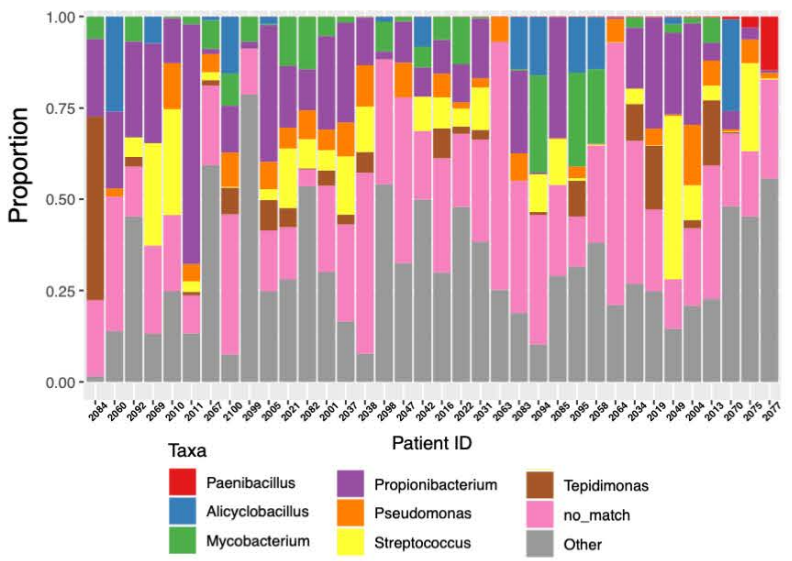

F

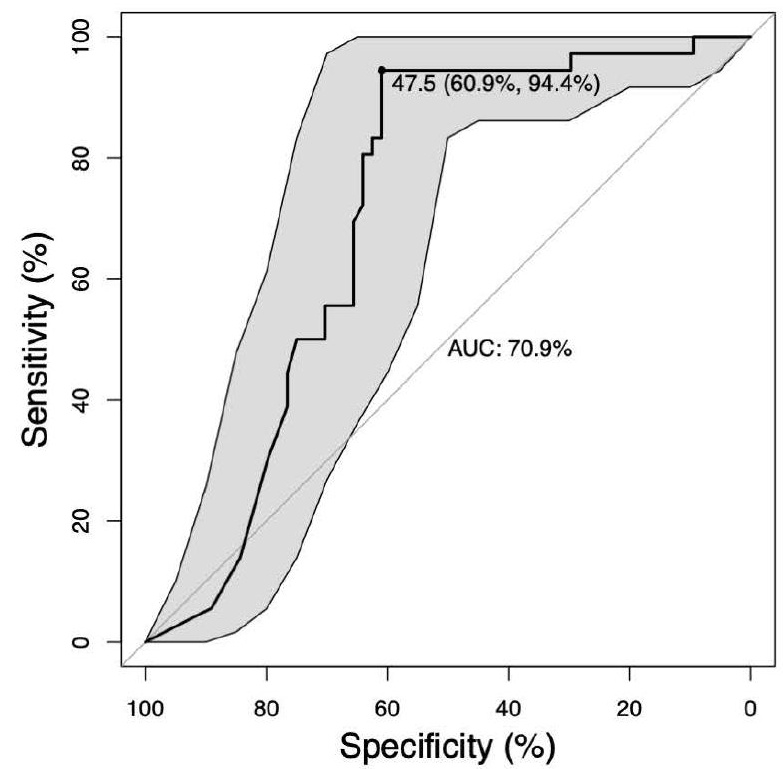


Figure 3

A

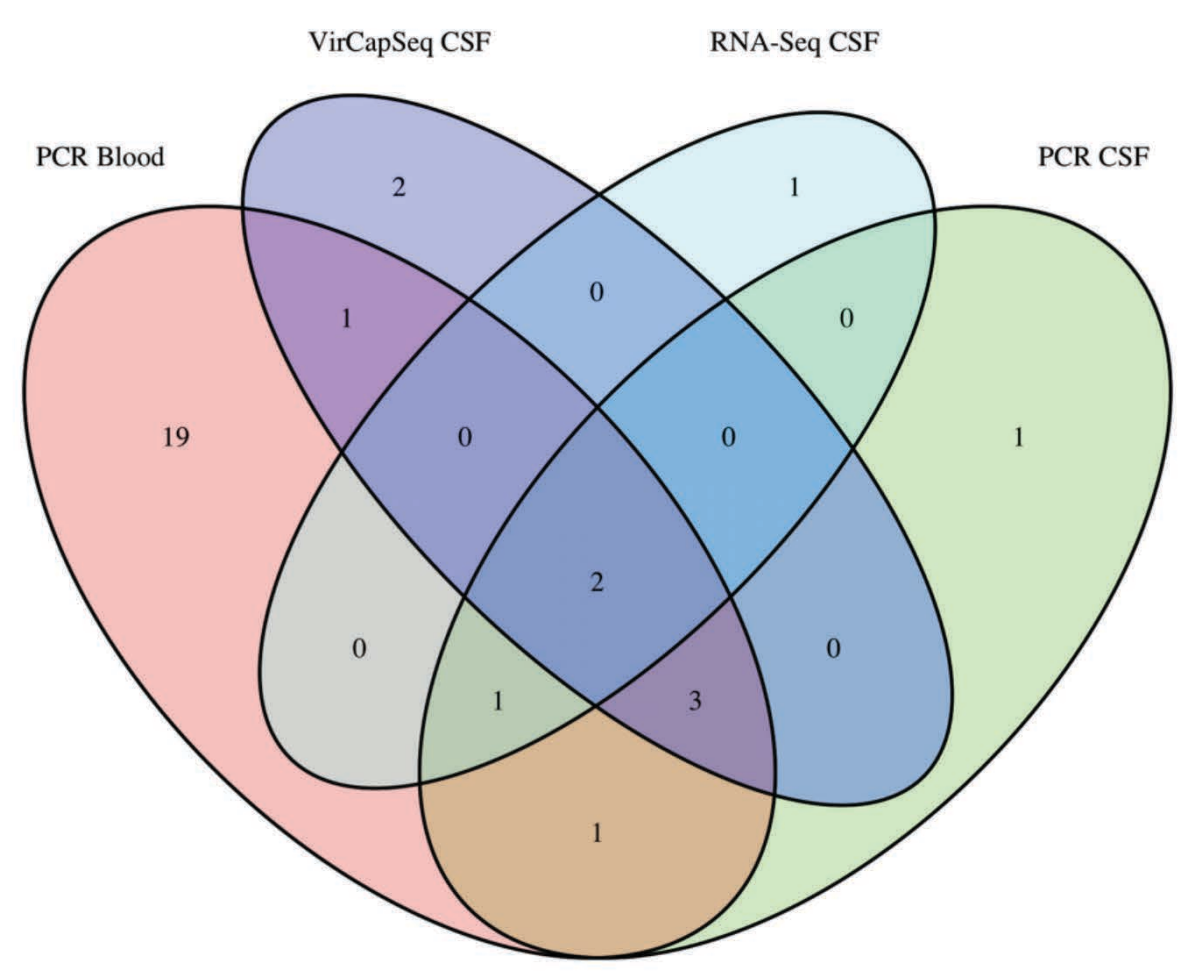

C

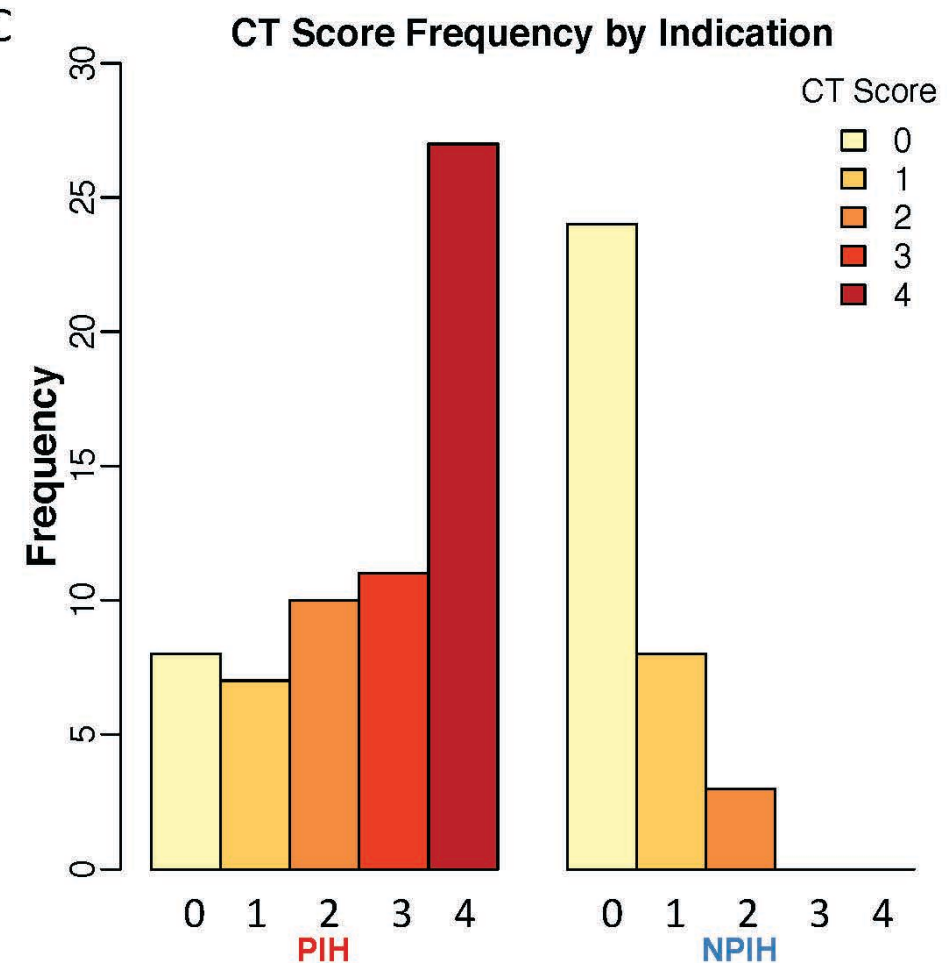

B
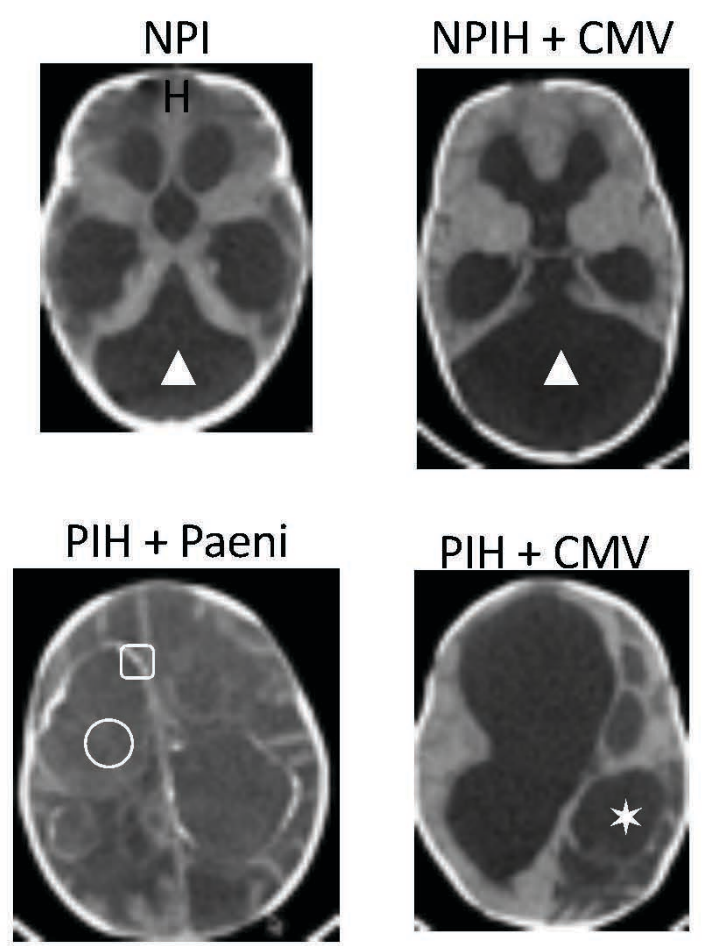

D
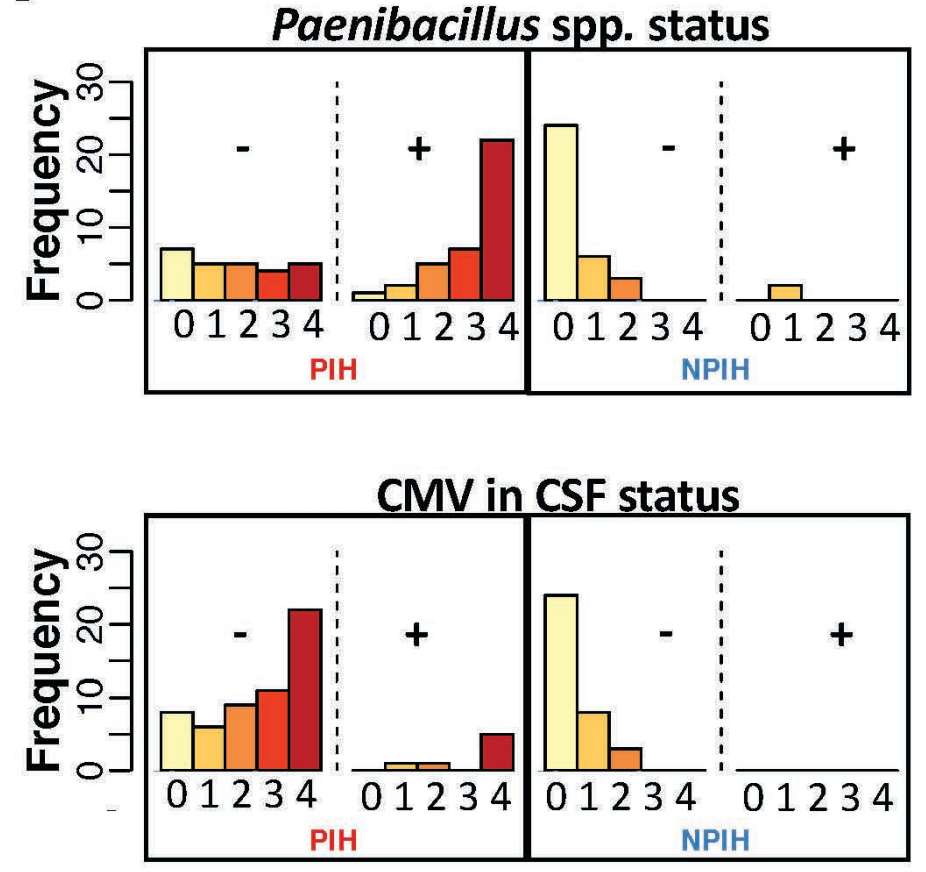

E TDP (nmol/L) levels in Bloowe

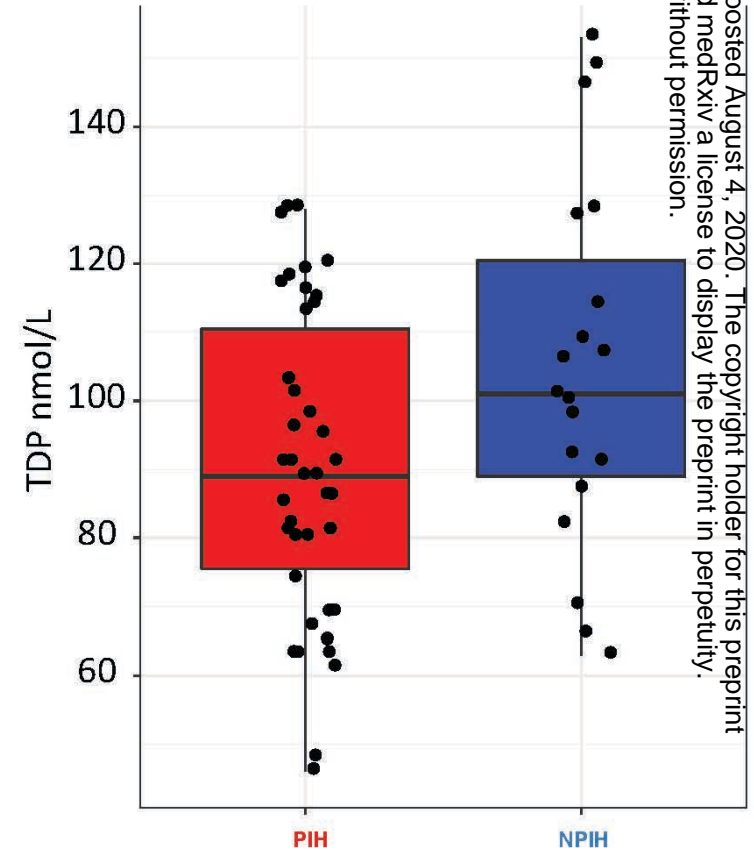

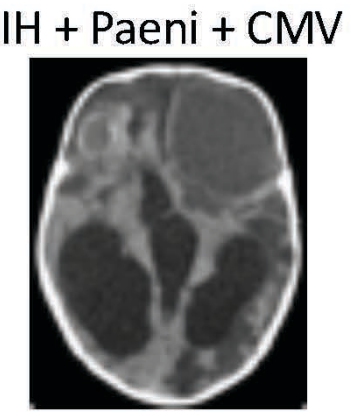

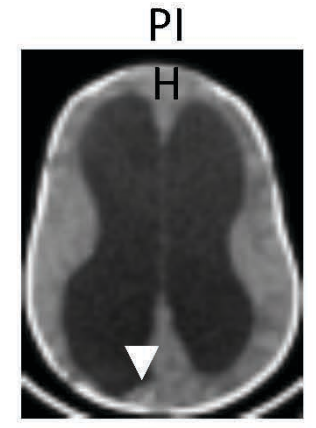

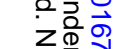
政 of बis

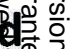




\section{Figure 4}

A Paenibacillus spp. relative abundance by age

B CSF WBC count (cell/ $\mu \mathrm{L}$ ) by Paeni status and indication C

WAZ by Paenibacillus spp. status and indication
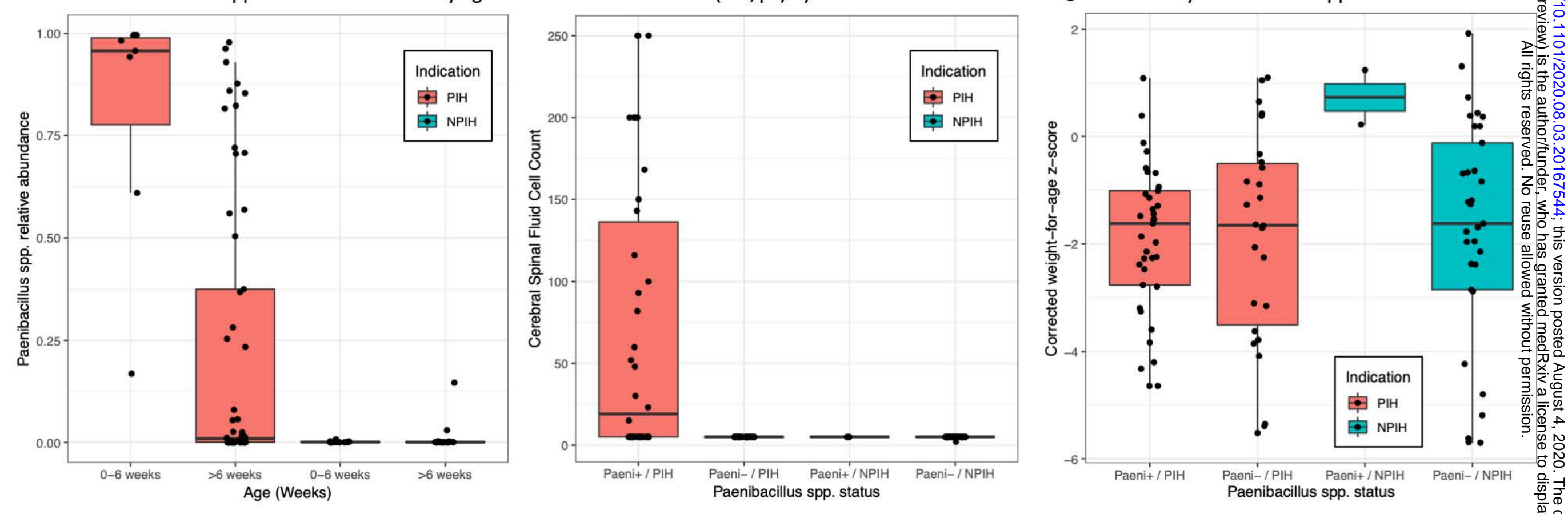
A

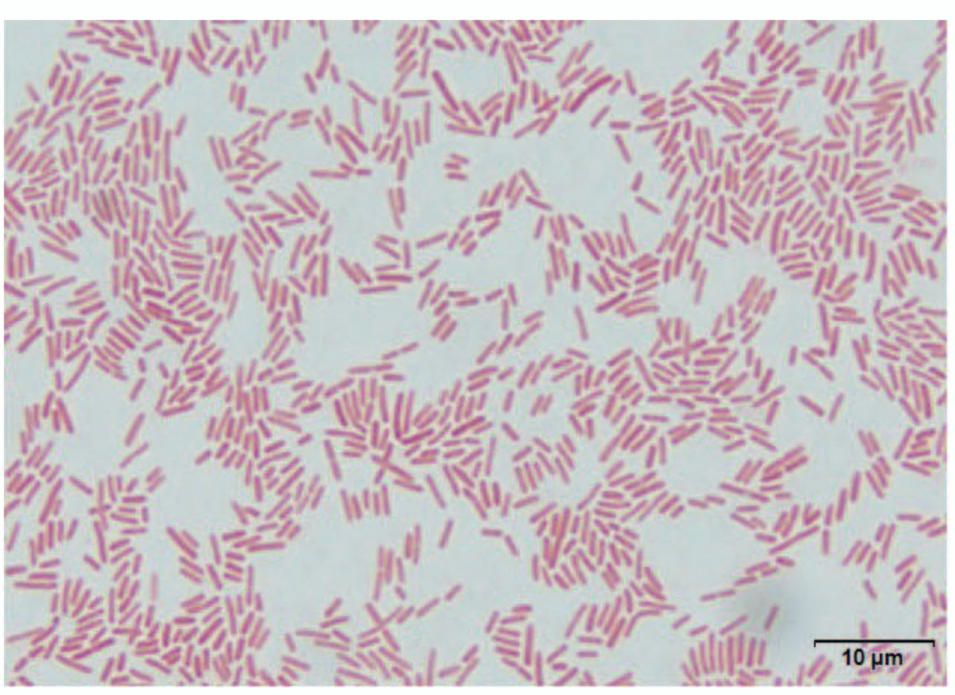

B $\quad \mathrm{CDS}$

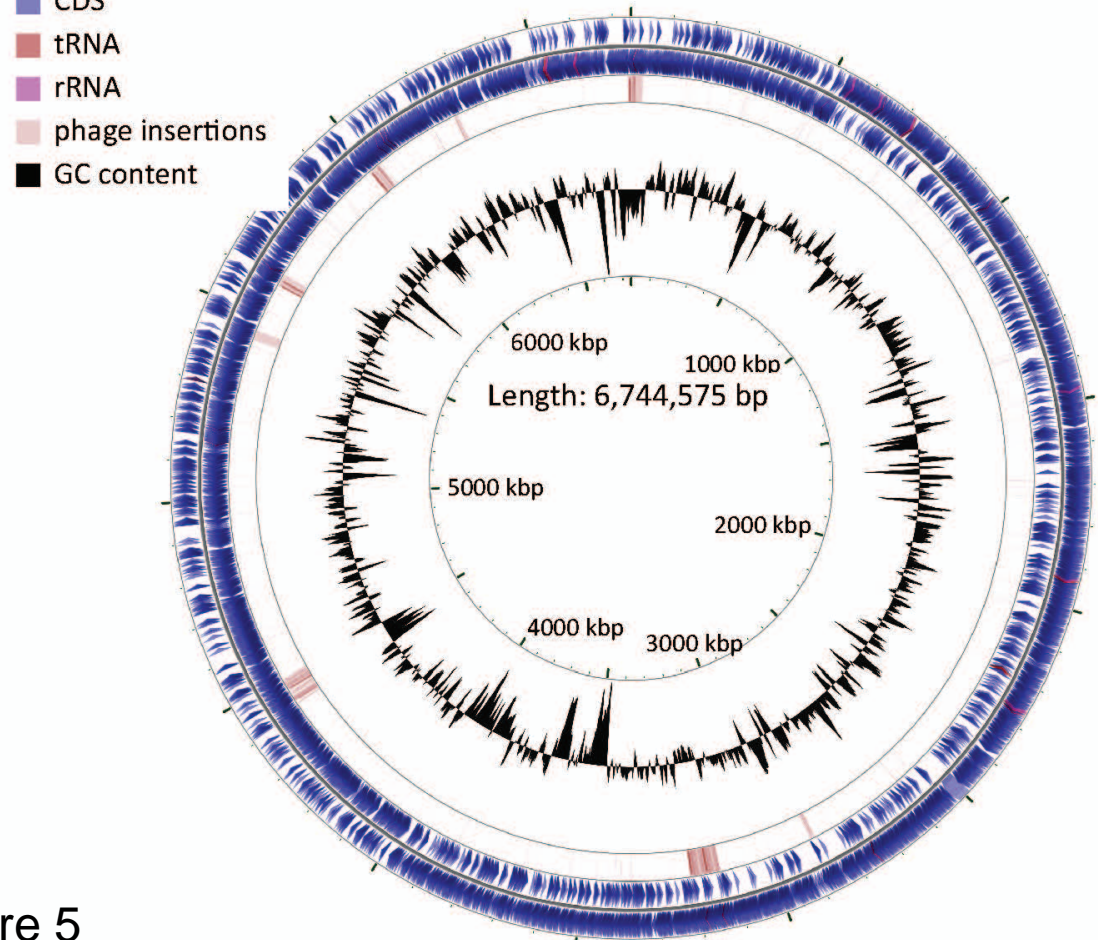

Figure 5
C

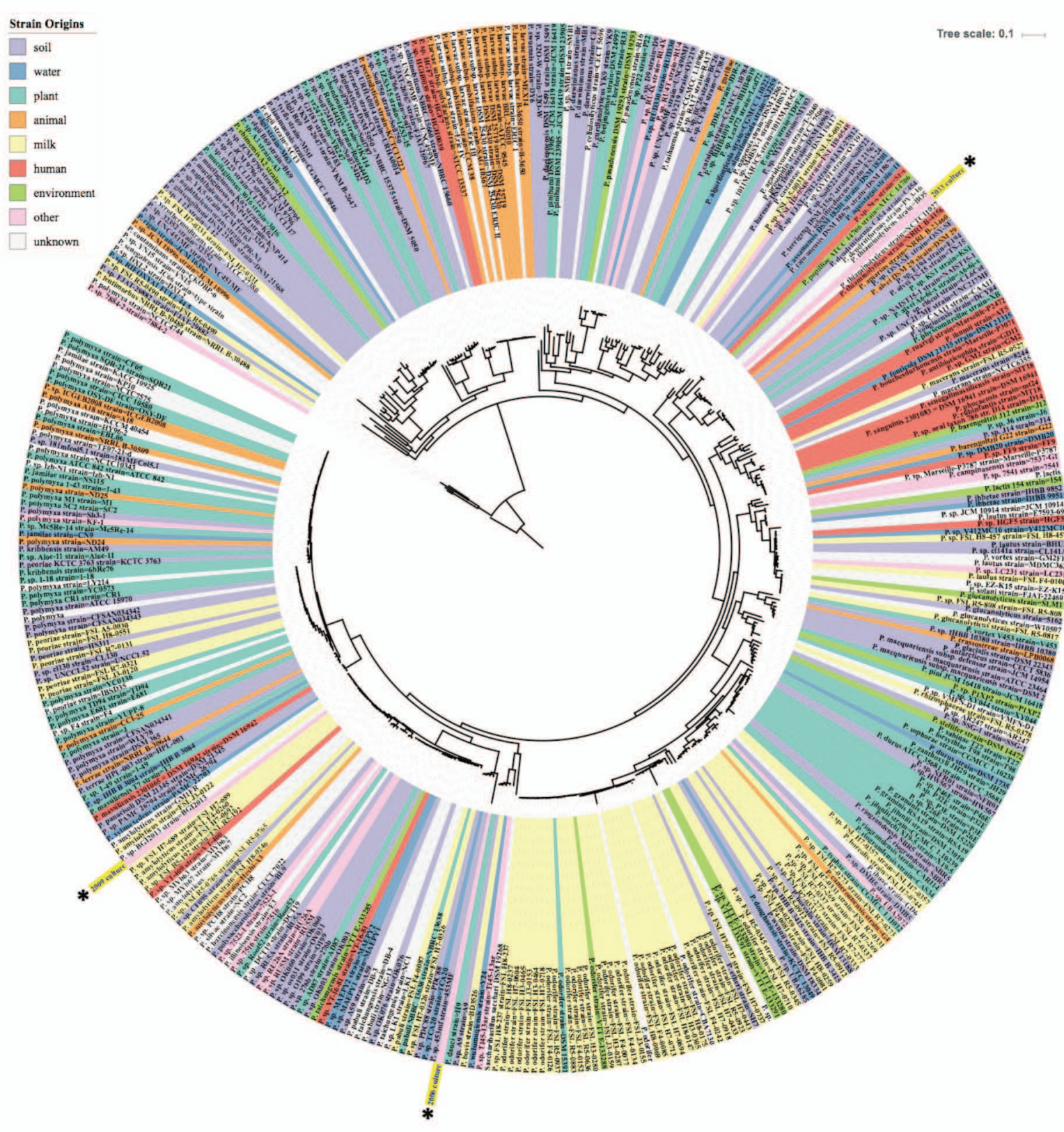


Figure 6

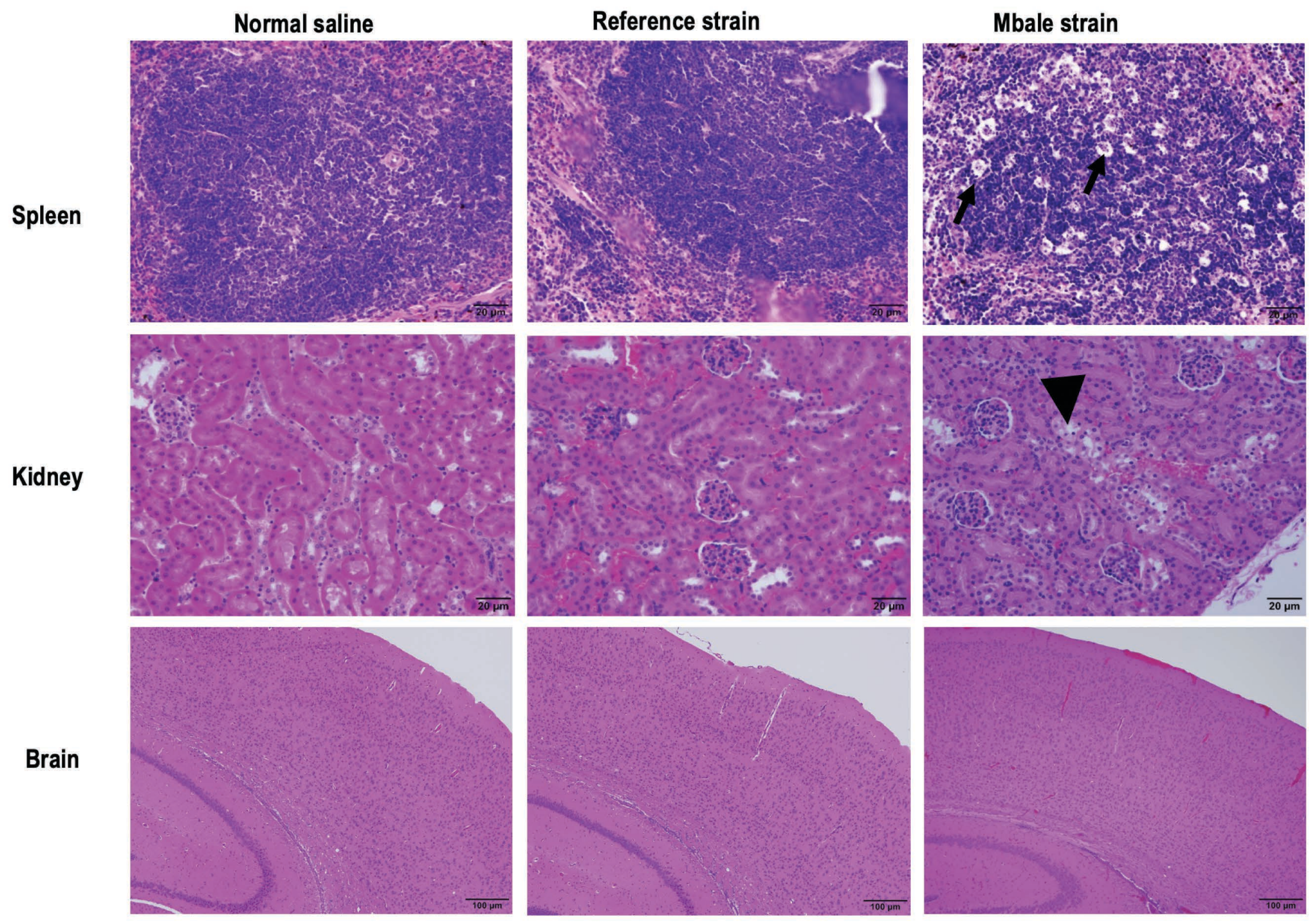




\section{Supplementary Material}

\section{The Bacterial and Viral Complexity of Postinfectious Hydrocephalus in Uganda}

February 25, 2020

Supplementary Material $\quad 1$

$\begin{array}{ll}\text { Microbial Characterization } & 3\end{array}$

Extraction, Amplification, and Sequencing 3

Fresh Frozen CSF Samples 3

Nucleic Acid Extraction of Fresh Frozen CSF Samples 3

Bacterial V1-V4 16s rRNA gene and Fungal ITS2 amplification 4

V4 Illumina Sequencing of bacterial 16s rDNA 4

Real-time Quantitative PCR (qPCR) of Paenibacillus spp. from CSF 4

$\begin{array}{ll}\text { Preserved CSF Samples } & 5\end{array}$

Nucleic Acid Extraction of Preserved CSF Samples $\quad 5$

Bacterial 16S rRNA Library Prep and Sequencing with Primer-extension PCR 5

$16 S$ Analysis $\quad 6$

In silico V1-V2 and V4 amplicon region characterization 6

$\begin{array}{ll}\text { OTU Matrix Generation } & 7\end{array}$

16S OTU Processing from Fresh Frozen CSF Samples $\quad 7$

16S OTU Processing from Preserved CSF Samples $\quad 7$

$\begin{array}{ll}\text { Characterization of samples and clinical association } & 7\end{array}$

$\begin{array}{ll}\text { Microbial Overview } & 7\end{array}$

Similarity and diversity analysis $\quad 8$

Differential abundance analysis $\quad 8$

Bacterial Isolate Whole Genome Sequencing and Assembly 8

DNA Sequencing $\quad 8$

Bacterial Genome Assembly $\quad 9$

Paenibacillus thiaminolyticus Identification and Characterization 9

Phylogenetic Analyses of V1-V4 from Paenibacillus 9

Characterization for Organisms Recovered through Culture 10

Taxonomic Placement using Genomic Marker Genes 10 
Bacterial Antibiotic Sensitivity Testing 11

Animal Model Virulence Testing 11

Viral and Parasite Characterization 11

$\begin{array}{ll}\text { Parasite and viral PCR } & 11\end{array}$

VirCapSeq-VERT 12

Viral RNA Sequencing 12

Wet lab methods for RNA and sequencing $\quad 12$

PCR validation $\quad 12$

$\begin{array}{ll}\text { Computational analysis and pipeline } & 13\end{array}$

Supplementary Figures 14

Supplementary Figure 1: CT Scans. 14

Supplementary Figure 2: Spatial Statistics. 15

Supplementary Figure 3: Phylogenetic tree for 16S V1-V4 sequences 16

Supplementary Figure 4: Further analysis of the microbial 16S community 18

Supplementary Figure 5: OTU Heatmaps. 19

Supplementary Figure 6: qPCR vs Age, CT Score, and Cell Counts. 20

Supplementary Figure 7: CT Score Frequencies. 21

Supplementary Tables $\quad 22$

Supplementary Table 1: Primer Table.

Supplementary Table 2: Fresh Frozen PCR and Sequencing. 26

Supplementary Table 3: Differential Abundance. 31

Supplementary Table 4: Viral Results.

Supplementary Table 5: Demographics with and without Paenibacillus. 34

Supplementary Table 6: Paenibacillus vs CMV. 36

Supplementary Table 7: CT Score vs CMV. 37

Supplementary Table 8: Culture Media. 38

Supplementary Table 9: Culture Results. $\quad 39$

Supplementary Table 10: Biochemical testing of $P$. thiaminolyticus. $\quad 41$

Supplementary Table 11: Antibiotic Resistance. 44

Supplementary Table 12: Virulence Testing.

Supplementary References $\quad 46$ 
medRxiv preprint doi: https://doi.org/10.1101/2020.08.03.20167544; this version posted August 4, 2020. The copyright holder for this preprint

(which was not certified by peer review) is the author/funder, who has granted medRxiv a license to display the preprint in perpetuity.

All rights reserved. No reuse allowed without permission.

\section{Microbial Characterization}

We describe in detail the wet lab and computational methods for microbial characterization as well as $P$. thiaminolyticus sequencing and assembly. $16 \mathrm{~S}$ rRNA gene amplicon sequencing was employed to initially characterize the bacterial flora present in patients' CSF for the characterization of dominant organisms and potential pathogen detection. 16S rRNA amplicon sequencing is commonly used for microbial community characterization, including differential abundance analysis. However, a limitation to 165 rRNA amplicon sequencing is a lack of taxonomic resolution, where organisms are often only identifiable to the genus or family level.

Through targeted amplicon sequencing we were able to characterize the flora and evaluate abundant and variable taxa within postinfectious hydrocephalus $(\mathrm{PIH})$ cases and those differentially abundant between PIH cases and non-postinfectious hydrocephalus (NPIH) controls. Noticeably, we identified a Paenibacillus taxa both dominant and differentially abundant in $\mathrm{PIH}$ cases. Following detection, we isolated the organism, performed quantification using qPCR, biochemical testing, matrix-assisted laser desorption/ionization time-of-flight (MALDI-TOF) mass spectrometry, and marker gene taxonomy placement following genome assembly. All primers for these methods and their appropriate references are listed in Table S1.

\section{Extraction, Amplification, and Sequencing}

Below we present the extraction, amplification, and sequencing details for the fresh frozen and preserved CSF samples.

\section{Fresh Frozen CSF Samples}

Nucleic Acid Extraction of Fresh Frozen CSF Samples

Prior to extraction, all tubes, columns, $0.1 \mathrm{~mm}$ and $0.5 \mathrm{~mm}$ glass beads (MoBio, CA, USA) and $1 \mathrm{~mL}$ extraction reagent aliquots were UV-irradiated twice at a distance of one inch from UV bulbs and at a setting of $3000 \times 100 \mu \mathrm{J} / \mathrm{cm}^{2}$ in a spectroLinker XL-1500 UV crosslinker (Spectronics Corporation, NY, USA). All of the kit extraction reagents (liquid) were aliquoted into $2 \mathrm{~mL}$ tubes in a UV hood at a volume not exceeding $1 \mathrm{~mL}$ and were UV-irradiated as above. To control for any remaining contamination, ten extraction reagent controls (blank extractions, negative extraction controls) were also included. Nucleic acid from fresh frozen CSF was extracted using the QIAgen AllPrep DNA/RNA kit (QIAgen, MD, USA), with some modifications. Before extraction, $1.5 \mathrm{~mL}$ of CSF was first centrifuged at $5600 \mathrm{rpm}$ for 10 minutes at $4^{\circ} \mathrm{C}$ to pellet all cells and $500 \mu \mathrm{L}$ of supernatant was removed for viral analyses. To the remaining 1.0 $\mathrm{mL}$ of CSF used for bacterial and fungal analysis, Buffer RLT with $0.01 \%$ ß-mercaptoethanol (600 $\mathrm{mL}$ and $700 \mathrm{ml}$, respectively) and $3 \mu \mathrm{L}$ of DX reagents (QIAgen, MD, USA) were added along with $0.1 \mathrm{~mm}$ and $0.5 \mathrm{~mm}$ glass beads. Samples were disrupted in a Tissue Lyser (QIAgen, USA) for five minutes at $30 \mathrm{~Hz}$ followed by proteinase $\mathrm{K}$ digestion (6 mAU, Novagen, USA) done at $55^{\circ} \mathrm{C}$ for 30 minutes then all remaining steps were performed according to the manufacturer's protocol. RNA and DNA concentration and purity were measured with a NanoDrop ND-100 spectrophotometer (NanoDrop Technologies, DE, USA) and stored at $-80^{\circ} \mathrm{C}$. 
medRxiv preprint doi: https://doi.org/10.1101/2020.08.03.20167544; this version posted August 4, 2020. The copyright holder for this preprint (which was not certified by peer review) is the author/funder, who has granted medRxiv a license to display the preprint in perpetuity.

All rights reserved. No reuse allowed without permission.

Bacterial V1-V4 16s rRNA gene and Fungal ITS2 amplification

For PCR of both bacterial 16S rRNA and fungal ITS from fresh frozen CSF, consumables and prepared master mix (without primers) were UV-irradiated in a SpectroLinker XL-1500 UV crosslinker $\left(3000 \times 100 \mu \mathrm{j} / \mathrm{cm}^{2}\right)$ prior to PCR setup. Once the prepared master mix was UV-treated, primers were added and a restriction digest was performed using Sau3AI at $37^{\circ} \mathrm{C}$ for 30 minutes then chilled on ice for 5 minutes prior to template DNA being added. The following controls were used for all reactions: ten negative extraction control, three negative PCR controls (no template), and three positive PCR controls (DNA from human stool for bacteria or soil for fungi) included. Primers for 16S V1-V4 amplification were 27F.1 and 805R and primers for ITS2 amplification were ITS3F and ITS4R. Each $20 \mu \mathrm{L}$ PCR reaction consisted of $1 X$ Accuprime Buffer II, 0.75 units of Accuprime Taq DNA Polymerase High Fidelity (Life Technologies, Thermo Fisher, USA), 2.5 units of Sau3Al restriction enzyme, $400 \mathrm{nM}$ of each primer and $5 \mu \mathrm{L}$ of the extracted DNA. For 16S rRNA amplification, cycling conditions were as follows: $95^{\circ} \mathrm{C}$ for $5 \mathrm{~min}$, followed by 40 cycles of $95^{\circ} \mathrm{C}$ for $30 \mathrm{~s}, 52^{\circ} \mathrm{C}$ for $1 \mathrm{~min}, 72^{\circ} \mathrm{C}$ for $1.5 \mathrm{~min}$, followed by a final elongation step at $72^{\circ} \mathrm{C}$ for $7 \mathrm{~min}$. For ITS2, cycling conditions were the same except the extension time at $72^{\circ} \mathrm{C}$ was 1 minute during cycling and the final extension at $72^{\circ} \mathrm{C}$ was 5 minutes.

PCR products were run on a $1 \%$ agarose gel stained with GelGreen (Biotium, CA, USA). None of the extraction reagent controls or PCR reagent controls produced any signal on agarose gels. Visible bands were excised from the gel and purified using the QIAgen Gel Extraction kit according to manufacturer's guidelines. Purified amplification products were ligated into the pGEM-T Easy vector (Promega Corporation, WI, USA) and inserts (at least 5 clones per sample) were sequenced by Sanger sequencing (Genewiz, NJ, USA).

V4 Illumina Sequencing of bacterial 16s rDNA

DNA from fresh frozen CSF samples were amplified with composite barcoded primers targeting the V4 region of the bacterial 16S rRNA gene to generate libraries for Illumina MiSeq sequencing according to the Earth Microbiome Project standard protocol (http://www.earthmicrobiome.org/emp-standard-protocols/16s/) with minor modifications (56). The same decontamination techniques were employed as described above, except that two restriction enzymes were used to decontaminate PCR reagents in each reaction, 2 units each of Sau3AI and Acil. The same decontamination techniques were employed as described in full length 16S and ITS2 PCR amplifications techniques described above. The PCR cycling conditions were as follows: $94^{\circ} \mathrm{C}$ for $5 \mathrm{~min}, 40$ cycles of $94^{\circ} \mathrm{C}$ for $20 \mathrm{~s}, 53^{\circ} \mathrm{C}$ for $25 \mathrm{~s}, 68^{\circ} \mathrm{C}$ for $45 \mathrm{~s}$ and a final extension at $68^{\circ} \mathrm{C}$ for $10 \mathrm{~min}$. Amplification products $(2 \mu \mathrm{l})$ were run on a $1 \%$ agarose gel stained with GelGreen (Biotium, CA, USA) to verify amplification and negative reactions were verified on a BioAnalyzer. None of the extraction reagent controls or PCR reagent controls produced any signal on agarose gels or BioAnalyzer. PCR products were further purified using Ampure magnetic purification beads (Beckman Coulter Life Sciences). Ampure purified products were quantified with the Quanti-iT PicoGreen dsDNA Assay Kit (Invitrogen). Equimolar ratios of each sample were combined to create DNA pools of barcoded libraries for sequencing on an Illumina MiSeq.

Real-time Quantitative PCR (qPCR) of Paenibacillus spp. from CSF

Paenibacillus species specific qPCR was performed targeting 16S rDNA as previously described with modifications (https://www.sciencedirect.com/science/article/pii/S0022201111001108?via\%3Dihub). For 
medRxiv preprint doi: https://doi.org/10.1101/2020.08.03.20167544; this version posted August 4, 2020. The copyright holder for this preprint (which was not certified by peer review) is the author/funder, who has granted medRxiv a license to display the preprint in perpetuity.

All rights reserved. No reuse allowed without permission.

absolute quantitation, DNA standards for Paenibacillus were constructed by PCR amplifying DNA obtained directly from Paenibacillus-positive CSF samples from this study. Purified amplification products were ligated into the pGEM-T Easy vector (Promega Corporation, WI, USA) and confirmed by Sanger sequencing. After verifying the plasmid insert sequence, 10 -fold serial dilutions of plasmids were generated, ranging from $5 \times 10^{6}$ to 5 copies and were spiked with salmon sperm DNA $(2.5 \mathrm{ng} / \mu \mathrm{L})$. PCR efficiency for plasmid standards was above $90 \%$ with correlation coefficients ranging from 0.996 to 1 , and sensitivity was 5 copies. Each $25 \mu \mathrm{L}$ realtime PCR reaction consisted of 1x TaqMan Universal PCR Master Mix (Applied Biosystems, Thermo Fisher Scientific, USA), $5 \mu \mathrm{L}$ of fresh frozen CSF DNA and primers (PaeniF and PaeniR,250 nM) and a probe (PaeniProbe, $300 \mathrm{nM}$ ). An ABI Step-One Plus Real-time PCR system (Applied Biosystems) was used to perform all real-time PCRs using the following cycling conditions: initial denaturation at $95^{\circ} \mathrm{C}$ for 15 minutes followed by 45 cycles at $95^{\circ} \mathrm{C}$ for $15 \mathrm{sec}$ and $60^{\circ} \mathrm{C}$ for $1.5 \mathrm{~min}$. All samples were run in duplicate for each assay, and average copy number was calculated from duplicate reactions. Final results are presented as total Paenibacillus spp. 16S rDNA copies per $\mathrm{mL}$ of CSF.

\section{Preserved CSF Samples}

Nucleic Acid Extraction of Preserved CSF Samples

Nucleic acid extractions on DNA/RNA Shield (Zymo, CA, USA) preserved samples were performed with reagents and consumables UV-treated in a PCR Workstation for 15 minutes. Each batch of extraction included a water control in which $500 \mu \mathrm{L}$ of elution buffer was put through all extraction steps. DNA was extracted from shield samples using $500 \mu \mathrm{L}$ of mixed sample using ZymoBIOMICS DNA Miniprep Kit (Zymo, CA, USA) with bead lysis using $0.15 \mathrm{~mm}$ and $0.5 \mathrm{~mm}$ ZrOBO beads in Bullet Blender (Next Advance, NY, USA) at high speed for 5 minutes. After lysis, the manufacturer's protocol was followed with proteinase $\mathrm{K}$ digestion and two elutions of $50 \mu \mathrm{L}$ with elution buffer heated to $65^{\circ} \mathrm{C}$. RNA was extracted from shield samples using TRIzol ${ }^{\mathrm{TM}}$ LS Reagent and Direct-zol ${ }^{\mathrm{TM}}$ RNA MiniPrep Plus kit. Samples were processed with two aliquots of $250 \mu \mathrm{L}$ mixed with $750 \mu \mathrm{L}$ of TRIzol ${ }^{\mathrm{TM}}$ LS Reagent. After bead lysis, $200 \mu \mathrm{L}$ of chloroform was added, incubated at room temperature for 15 minutes then centrifuged at $12,000 \mathrm{~g}$ for 15 minutes at $4^{\circ} \mathrm{C}$. Once separated the aqueous layers from the two aliquots were put into the same tube. Then each organic layer was re-suspended in $400 \mu \mathrm{L}$ of water and centrifuged again for 5 minutes. The $1.6 \mathrm{~mL}$ of aqueous phases were combined with $1.6 \mathrm{~mL}$ of $100 \%$ ethanol and put through the Zymo-Spin ${ }^{\mathrm{TM}}$ IC Column twice and proceeded per manufacturer's protocol.

Bacterial 16S rRNA Library Prep and Sequencing with Primer-extension PCR

Primer-extension PCR (PE-PCR) of the 16S rRNA V1-V2 region using primer 336R with M13 and 27F with previously described techniques by (57) with a few modifications. To control temperature appropriately the initial annealing step was done on the the Hybex microsample incubator (Scigene, CA, USA). To avoid any additional contamination, MolTaq 16S Mastermix (Molzym GmbH \& Co Kg, Germany) was used for amplification following manufacturer's protocol with the following optimized PCR cycling conditions: 35 cycles of 15 seconds at $95^{\circ} \mathrm{C}$ and 2 minutes at $60^{\circ} \mathrm{C}$. All of the PE-PCR product was put into a $1 \times$ AMpure XP (Beckman Coulter) cleanup and eluted in $50 \mu \mathrm{L}$ of $10 \mathrm{mM}$ Tris $\mathrm{pH}$ 8. Library preparation was performed using the Hyper Prep Kit (KAPA Biosystems, USA) according to manufacturer's protocol, 
medRxiv preprint doi: https://doi.org/10.1101/2020.08.03.20167544; this version posted August 4, 2020. The copyright holder for this preprint (which was not certified by peer review) is the author/funder, who has granted medRxiv a license to display the preprint in perpetuity.

All rights reserved. No reuse allowed without permission.

adjusting adapter concentration based on total DNA input. Libraries were subsequently enriched with 7 cycles of PCR using the Library Amplification Module (KAPA Biosystems, USA). Libraries were quantified using Agilent Bioanalyzer DNA 1000 chip, pooled to an appropriate concentration and another $1 \mathrm{x}$ clean-up was performed. Sequencing was performed per the manufacturer's protocol on Illumina's Miseq using the 600 cycle v3 kit at 9 pM and $7 \%$ phiX with an aimed depth at 500k reads/sample.

\section{S Analysis}

Below we present the analytical overview of the $16 \mathrm{~S}$ analyses on our fresh frozen and preserved CSF samples. We first highlight the in silico comparison of V1-V2 and V4 amplicon regions for potential characterization based on Greengenes databases. Afterwards, we present our process for generating Operational Taxonomic Unit (OTU) count tables, annotation, differential abundance analysis, and comparison of diversity by sample type.

\section{In silico V1-V2 and V4 amplicon region characterization}

We define taxonomic resolution as the ability to differentiate between groups within a taxonomic level, for example differentiating between species within a genus. Taxonomic resolution can vary by clade and amplicon regions, though the extent to which it varies is not well characterized. Below in Section Comparison of V1-V2 and V4 we highlight the differential potential to speciate Paenibacillus taxa followed by the comparison of diversity levels and relationship to CSF cell count.

We utilized metagenomeFeatures (58) and the MgDb annotation packages (59) to characterize taxonomic resolution for a specific clade and amplicon region, specifically for the Paenibacillus genus and V1-V2 and V4 regions using the Greengenes 13.5, greengenes13.5MgDb.us (http://bioconductor.org/packages/release/data/annotation/html/greengenes13.5MgDb.html). The number of sequences assigned to specific Paenibacillus species, range from 199 for Paenibacillus amylolyticus to 2 for Paenibacillus illinoisensis. Sequences only classified to the genus level, "Unassigned", is the most abundant group, 2308.

16S rRNA amplicon sequencing taxonomic resolution for Paenibacillus species were compared by calculating within and between species pairwise distances. In order to differentiate between species, the pairwise distances within species amplicon sequences must be less than the between species distances. Additionally, the difference in amplicon sequence pairwise distances between and within species must be greater than the sequencing error rate to detect the difference. For our taxonomic resolution analysis we use in silico PCR to extract the V1-V2 and $\mathrm{V} 4$ regions of the $16 \mathrm{~S}$ rRNA sequences. We generated a pairwise distance matrix for the two regions and compared the within and between species pairwise distances using DECPIHER (https://decipher.sanger.ac.uk/). For our in silico PCR we used the bacterial portion of the PCR primers from Table S1 as:

\begin{tabular}{|c|c|c|}
\hline Region & Forward & Reverse \\
\hline V1-V2 & 27F - AGAGTTTGATCATGGCTCAG & 336R - CACTGCTGCSYCCCGTAGGAGTCT \\
\hline V4 & 515F - GTGCCAGCMGCCGCGGTAA & 806R - GGACTACHVGGGTWTCTAAT \\
\hline
\end{tabular}


medRxiv preprint doi: https://doi.org/10.1101/2020.08.03.20167544; this version posted August 4, 2020. The copyright holder for this preprint (which was not certified by peer review) is the author/funder, who has granted medRxiv a license to display the preprint in perpetuity.

All rights reserved. No reuse allowed without permission.

For the V1-V2 and V4 analyses, only sequences with the appropriate expected amplicon lengths are extracted (318 bp and $252 \mathrm{bp}$ for the $\mathrm{V} 1-\mathrm{V} 2$ and $\mathrm{V} 4$ regions respectively). The overall pairwise distance is greater between species than within species for the Paenibacillus genus.

\section{OTU Matrix Generation}

An open-reference OTU matrix was generated using Qiime version 1.9 .1 (60) for all downstream analyses. In the process, reads were clustered using a $97 \%$ similarity cutoff with uclust version 1.2.22 and aligned using PyNAST v1.2.2 against a modified core Greengenes database vgg_13_8 (61) that included 16S references for three strains successfully isolated from clinical samples (see below). De novo OTUs were generated for unaligned reads. OTU centers were filtered due to chimeric detection using ChimeraSlayer (via microbiomeutil_r20110519) (62). OTU centers were assigned a taxonomic annotation using RDP Classifier v2.0.2 (63). Further taxonomic assignment for Paenibacillus of unannotated OTUs consisted of annotating centers against the NR database (updated with NCBI on Oct. 3rd, 2018) with BLAST.

\section{S OTU Processing from Fresh Frozen CSF Samples}

Two thousand one hundred and five $(2,105)$ OTUs were generated from the process described above. Of these, 658 passed chimera checking, were detected in more than five samples or represented at least 20 sequences in a single sample, and were included in further analysis. The number of OTUs per sample ranged from 51 to 296, with a median of 125 and an average of 137. The mean OTU size was 2328, ranging from 5 (by definition) to 736,735 (with median OTU size $=58$ sequences). Among these, approximately $56 \%$ of OTU centers were annotated to the genus level using the Greengenes database, while others were annotated at family or higher levels.

16S OTU Processing from Preserved CSF Samples

Five thousand eighty-eight $(5,088)$ OTUs were generated from targeted $16 \mathrm{~S}$ rRNA amplicon sequencing. Of these, 1,767 passed chimera checking, were detected in more than five samples or represented at least 20 sequences in a single sample, and were included in further analysis. The number of OTUs per sample ranged from 22 to 429, with a median of 140 and an average of 156. The mean OTU size was 3,331, ranging from 5 (by definition) to 2,071,935 (with median OTU size $=126$ sequences). Among these, approximately $66 \%$ of OTU centers were annotated to the genus level using the Greengenes database, while others were annotated at family or higher levels.

\section{Characterization of samples and clinical association}

Microbial Overview

In processing samples, we prepared bar plots of the most abundant organisms present. Caution in interpretation of the background microbial diversity and community is necessary as CSF samples are low-biomass samples known to yield PCR and other sequencing artifacts (64). That being said, a number of patient samples yielded many reads from single taxa not known to associate with sequencing artifacts. Fig. 2C and 2D and Tables S3 and S4 highlight 
medRxiv preprint doi: https://doi.org/10.1101/2020.08.03.20167544; this version posted August 4, 2020. The copyright holder for this preprint (which was not certified by peer review) is the author/funder, who has granted medRxiv a license to display the preprint in perpetuity.

All rights reserved. No reuse allowed without permission.

the most abundant organisms from both preservative CSF (V1-V2 amplicon sequencing) and fresh frozen (V4 amplicon sequencing) samples, respectively.

Similarity and diversity analysis

The background microbial community and associations with clinical samples for the fresh frozen and preserved samples were compared. In particular, we compared Paenibacillus abundances for matching pairs of samples calculated by aggregating annotated OTU normalized counts and log-transforming, highlighting the similarity in abundance for various OTUs. We observed similar clustering of patients by Paenibacillus spp. V1-V2 and V4 OTUs (Fig. 2E, Fig. S5).

Overall, diversity was lower in V4 samples potentially due to both the shorter V4 region and a different strategy of reagent contamination reduction, resulting in fewer OTUs. Diversity was inversely correlated with CSF cell count with the predominance of a single dominant organism in those samples as would be expected (Fig. S4B). The detection of Paenibacillus spp. presence in PIH samples was observed across multiple batches; in particular, sequencing and extraction batching was performed with a mix of PIH and NPIH samples to control for any artifacts.

Differential abundance analysis

Differential abundance and presence/absence analysis was performed to compare PIH and NPIH taxa abundance and presence. For differential abundance analysis normalized counts were aggregated to the genera level and a log-normal regression model was applied using limma (https://bioconductor.org/packages/release/bioc/html/limma.html) with abundance as the outcome variable and indication status as the independent variable. Counts were normalized using cumulative sum scaling and aggregated to the genera clade (65). For differential presence/absence testing we applied Fisher's exact test on the presence/absence of each genus as defined by the presence of a positive count, also implemented within MetagenomeSeq (https://bioconductor.org/packages/release/bioc/html/metagenomeSeq.html). To account for multiple testing Benjamini and Hochberg's false discovery rate was applied (66).

\section{Bacterial Isolate Whole Genome Sequencing and Assembly}

\section{DNA Sequencing}

From cultured bacteria, high molecular weight DNA was prepared for optical mapping and both short and long read whole genome sequencing per the Prep Cell Culture DNA Isolation Protocol including the necessary Lysozyme digestion for bacterial cells (Bionano Genomics, CA, USA). PCR-free short read libraries were generated from 1 ug of E220 Focused Ultrasonicator (Covaris, USA) fragmented DNA, average insert size 400 bp with Hyper Prep Kit (KAPA Biosystems, USA). Final library pools were diluted to $10 \mathrm{pM}$, combined with $15 \%$ phiX, and sequenced to 10 million reads each with a MiSeq v3 600 cycle reagents. Long read sequencing library prep was performed using Hyper Prep kit (Kapa Biosystems, USA) and 1D Sequencing kit 
medRxiv preprint doi: https://doi.org/10.1101/2020.08.03.20167544; this version posted August 4, 2020. The copyright holder for this preprint (which was not certified by peer review) is the author/funder, who has granted medRxiv a license to display the preprint in perpetuity.

All rights reserved. No reuse allowed without permission.

(Oxford Nanopore Technologies, UK) following the manufacturer's protocol. Sequencing was done using the MinION with the SQK-LSK108 SpotON flow cell following manufacturers protocol.

\section{Bacterial Genome Assembly}

Reads were aligned to hg38 using Bowtie 2 v2.3.4.3 to remove any spurious human reads. SPAdes v1.3.11 (67) was used for de novo scaffold generation using Illumina short read sequencing. To correct reads with scaffolds generated from Illumina short reads Pilon was employed (68). Basecalling and reads from Minlon were preprocessed using Albacore (Oxford Nanopore Technologies, https://nanoporetech.com/) Canu was used to assemble the Minlon long-reads (69). To generate the hybrid scaffold from optical mapping and corrected Minlon sequencing scaffolds the following Bionano Software was used: Bionano Access v1.3.0, Bionano Tools v1.3.8041.8044 and Hybrid Scaffold v10252018.

\section{Paenibacillus thiaminolyticus Identification and Characterization}

Below we present the various methodologies applied for characterization. We initially characterize the V1-V4 16S gene Sanger sequencing of identified Paenibacillus cases from fresh frozen CSF and generate a tree for relative relationship. Then we grew several isolates in culture, performed whole genome sequencing described earlier, and performed taxonomic placement using genomic marker genes.

\section{Phylogenetic Analyses of V1-V4 from Paenibacillus}

Paenibacillus spp. V1-V4 16S rDNA sequences from fresh frozen CSF were phylogenetically compared to each other. Analyses were conducted using MEGA7 (70). Sequence alignments were based on representative 16S rDNA sequences obtained from PCR amplification using 27F.1 and 805R primers and subcloning (as described above) from CSF of individual PIH patients in this study. Primer sequences were trimmed from the sequences. 16S rDNA sequences from Paenibacillus isolates and related species in Genbank were trimmed to the length of the sequences obtained from the CSF of PIH patients.

The evolutionary history was inferred using the Neighbor-Joining method (71). The optimal tree with the sum of branch length $=1.20929307$ is shown in Fig. S3. The percentage of replicate trees in which the associated taxa clustered together in the bootstrap test (500 replicates) are shown next to the branches (72). The tree is drawn to scale, with branch lengths in the same units as those of the evolutionary distances used to infer the phylogenetic tree. The evolutionary distances were computed using the Kimura 2-parameter method (73), and are in the units of the number of base substitutions per site. The analysis involved 39 nucleotide sequences. All ambiguous positions were removed for each sequence pair. There were a total of 750 positions in the final dataset. 
medRxiv preprint doi: https://doi.org/10.1101/2020.08.03.20167544; this version posted August 4, 2020. The copyright holder for this preprint (which was not certified by peer review) is the author/funder, who has granted medRxiv a license to display the preprint in perpetuity.

All rights reserved. No reuse allowed without permission.

\section{Characterization for Organisms Recovered through Culture}

All 100 CSF samples were blindly cultured using six different media with varying inoculum and conditions listed in Table S8. If colonies grew on solid media, Gram stain and MALDI-TOF were performed to characterize the organism. For MALDI-TOF genus and species identification cutoff values were 1.7 and 2.0 respectively. If the BACTEC ${ }^{\mathrm{TM}}$ FX instrument flagged positive liquid culture bottles, a Gram stain and sub-cultures were performed as follows:

1) Positive PEDS bottles were subcultured onto $\mathrm{CHOC}$ and incubated at $37^{\circ} \mathrm{C}, 5 \% \mathrm{CO} 2$ for 5 days 2) Positive ANA bottles were subcultured onto $\mathrm{CHOC}$, anaerobic blood agar plate (ABAP) and incubated at $37^{\circ} \mathrm{C}$, for 5 days in $5 \% \mathrm{CO} 2(\mathrm{CHOC})$ or anaerobically (ABAP, Anoxomat System). For negative BACTEC ${ }^{\mathrm{TM}}$ liquid culture bottles gram stain was performed and blind cultures were done as follows: 1) For negative PEDSs bottles, subculture was done on $\mathrm{CHOC} / \mathrm{BAP}$ and incubated at $37^{\circ} \mathrm{C}, 5 \% \mathrm{CO} 2$ for 5 days 2) For negative ANA bottles, subculture was done on $\mathrm{CHOC}$, anaerobic blood agar plate (ABAP) and incubated at $37^{\circ} \mathrm{C}$, for 5 days in $5 \% \mathrm{CO} 2$ (CHOC) or anaerobically (ABAP, Anoxoimat Sysytem). Biochemical testing was performed using API $50 \mathrm{CH}$ strip following manufacturers protocol. MALDI-TOF was used for initial screening of clinical isolates, but whole genome sequencing was used for definitive classification of all Paenibacillus isolates.

Six CSF samples were positive for bacterial growth during initial incubation (within 14 days of incubation), and the results summarized in Table S9. In addition, there were 4 positive blind cultures. Two of the blind ANA cultures were positive for Propionibacterium acnes, 2018 and 2081, with MALDI-TOF scores of 2.28 and 2.26 respectively. A third ANA blind culture was positive and identified as Paenibacillus species with a MALDI-TOF score of 1.83. One of the blind PEDS cultures was positive and identified as Bacillus infantis with MALDI-TOF of 2.25. The API $50 \mathrm{CH}$ system with API CHB/E media (BioMerieux) was used for biochemical characterization of the organisms. After a 48h incubation, both 2033 and NRRL B-4156 were identified as $P$. thiaminolyticus at a $99.9 \%$ confidence level (Table S10).

\section{Taxonomic Placement using Genomic Marker Genes}

Paenibacillus genomes, $\mathrm{n}=438$, were downloaded from the Genbank ftp website (using the file ftp://ftp.ncbi.nlm.nih.gov/genomes/genbank/assembly summary genbank.txt, November 2018). The 16S rRNA sequences of the 438 genomes were compared to the SILVA database (v132) (74) to filter the non-Paenibacillus genomes, by removing genomes with 16S rRNA identity to Paenibacillus lower than $97 \%$ on at least 300 nucleotide alignment length using BLASTN (75).

Of the 438 genomes, 361 genomes were retained, due to fragmented $16 \mathrm{~S}$ rRNA or not matching Paenibacillus taxa, and added with the pool of the newly sequenced clinical strains 2033, 2006, 2009 and the genome Saccharibacillus sacchari DSM 19268 used to root the tree. For comparison, proteins in each genome were predicted using Prodigal (76), and 40 conserved phylogenetic marker proteins were extracted for each genome using the standalone software fetchMG v1.0 (77) and aligned using MUSCLE v3.8.425 (78). Duplicated markers in the genome were not included to reduce possible contaminant bias, and all genomes with fewer than 30 markers detected were not included in the tree. The aligned markers were then concatenated to produce a single chimeric amino acid sequence.

A phylogenetic tree was generated (Fig. 5C) using these chimeric concatenated sequences using FastTree v2.1.10 (79) using the options -gamma -pseudo -spr 4 -mlacc 3 - 
medRxiv preprint doi: https://doi.org/10.1101/2020.08.03.20167544; this version posted August 4, 2020. The copyright holder for this preprint (which was not certified by peer review) is the author/funder, who has granted medRxiv a license to display the preprint in perpetuity.

All rights reserved. No reuse allowed without permission.

slownni to account for partial markers and increase exhaustiveness. The Newick FastTree file was then visualized using iTOL (80).

The Paenibacillus isolation origins were manually explored using the $\mathrm{NCBI}$ and PATRIC website (81) and classified into 8 categories (animal, environment, human, milk, water, soil, plant, other) and considering rhizosphere isolation as a plant category. The isolation origin was then stored and structured into an iTOL TREE_COLORS file and display in the iTOL tree.

\section{Bacterial Antibiotic Sensitivity Testing}

A bacterial inoculum was prepared by emulsifying several well-isolated colonies from an overnight bacterial growth on agar plate into $3 \mathrm{ml}$ of sterile water to achieve the turbidity of 0.5 McFarland standard. S. aureus ATCC 29213 strain was used as quality control. A sterile swab soaked with inoculum suspension was used to inoculate a Mueller Hinton Agar with Blood plate $(15 \times 150 \mathrm{~mm})$. Plates were allowed to dry for $5 \mathrm{~min}$ to absorb excess moisture. Etest strips with antibiotics were placed on the plate within an equidistant pattern using a template. Plates were incubated at $37^{\circ} \mathrm{C}, 5 \% \mathrm{CO} 2$ for 20 hours and mean inhibitory concentration (MIC) read and interpreted according to Clinical \& Laboratory Standards Institute guidelines. The antibiotic resistance results are summarized in Table S11.

\section{Animal Model Virulence Testing}

For preparations of the bacterial culture for injection, bacteria grew for 18-24h on Trypticase Soy Agar (TSA II) with 5\% sheep blood (BD) (SBA) plates, and were then suspended, washed once, and resuspended in sterile saline. Then, 10-fold serial dilutions were prepared in sterile saline, and $100 \mu \mathrm{L}$ were plated on SBA. After 18-24h, growth was assessed and $\mathrm{CFU} / \mathrm{ml}$ in the original inoculum were estimated from the colony counts on the first plate on which 10-100 colonies grew.

\section{Viral and Parasite Characterization}

We describe in detail the wet lab and computational methods for viral characterization.

\section{Parasite and viral PCR}

Detection of Zika virus (ZIKV), dengue virus (DENV), chikungunya virus (CHIKV), West Nile virus (WNV) and human RNAse $\mathrm{P}$ gene was done using Cll-ArboViroPlex rRT-PCR assay (82).

For cDNA synthesis of Trypanosoma brucei, Trypanosoma cruzi, Parvovirus, Enterovirus, Plasmodium, and Salmonella typhi, Superscript III (Invitrogen cat\# 18080044) was used following the manufacturer's protocol. The cDNA was used with the same assays done with DNA listed below.

For testing of Plasmodium, Salmonella Typhi, Toxoplasmosis, Trypanosoma brucei, Trypanosoma cruzi, Parvovirus, and Enterovirus conventional PCR with DNA input was used using the primers and references in Table S1. Amplitaq Gold master mix (Life Technologies, cat 
medRxiv preprint doi: https://doi.org/10.1101/2020.08.03.20167544; this version posted August 4, 2020. The copyright holder for this preprint (which was not certified by peer review) is the author/funder, who has granted medRxiv a license to display the preprint in perpetuity.

All rights reserved. No reuse allowed without permission.

\#4398881) was used per the manufacturer's protocol with $25 \mu$ l volume with $1 \mu$ of primers (15 $\mu \mathrm{M})$ and $1 \mu \mathrm{l}$ of cDNA or DNA. For all cycling conditions, they were either unchanged from previous work referenced (Table S1) or they had the following modifications:

1) Parvovirus at $95^{\circ} \mathrm{C}$ for 15 minutes, followed by 40 cycles of $95^{\circ} \mathrm{C}$ for 30 seconds, $56^{\circ} \mathrm{C}$ for 30 seconds, $72^{\circ} \mathrm{C}$ for 30 seconds followed by $72^{\circ} \mathrm{C}$ for 5 minutes

2) Enterovirus at $95^{\circ} \mathrm{C}$ for 15 minutes, followed by 15 cycles at $95^{\circ} \mathrm{C}$ for 30 seconds, $65^{\circ} \mathrm{C}$ for 30 seconds (minus 1 degree per cycle), and $72^{\circ} \mathrm{C}$ for 30 seconds, followed by 30 cycles of $95^{\circ} \mathrm{C}$ for 30 seconds, $50^{\circ} \mathrm{C}$ for 30 seconds, $72^{\circ} \mathrm{C}$ for 30 seconds followed by $72^{\circ} \mathrm{C}$ for 5 minutes.

In addition to conventional PCR, a TaqMan qPCR assay was used to detect Salmonella typhi and Plasmodium independently. Taqman 2x Universal PCR MasterMix (Thermofisher Cat\# 4304437) was used in $25 \mu \mathrm{l}$ reactions with $5 \mu \mathrm{l}$ of cDNA and $0.5 \mu \mathrm{l}$ of $15 \mu \mathrm{M}$ primers and probe. Thermal cycling and detection was done on the CFX96 Real-Time PCR Detection System (BioRad). Following cycling conditions were used for amplification: $95^{\circ} \mathrm{C}$ for $2 \mathrm{~min}$, followed by 45 cycles of qPCR at $95^{\circ} \mathrm{C}$ for $15 \mathrm{~s}$ and $60^{\circ} \mathrm{C}$ for $1 \mathrm{~min}$. Fluorescence signal intensity was detected after completion of each qPCR cycle and data was collected using the CFX Manager ${ }^{\mathrm{TM}}$ Software.

\section{VirCapSeq-VERT}

For targeted viral detection, the capture technique VirCapSeq-VERT was performed as previously described (83). Low quality and poor complexity reads were filtered using PRINSEQ (v 0.20.2) and remaining reads were mapped with human host database using Bowtie 2 mapper 2.0.6 (84). Resulting reads were de novo assembled using MIRA (v4.0) assembler and homology search was performed on NCBI GenBank database (85). Both contigs and unique singletons from assembly were subjected to NCBI BLASTn, and unannotated sequences were further searched on non-redundant ( $n r)$ database using NCBI BLASTx. Based on BLASTn and BLASTx analysis viral sequences matching with Illumina reads and contigs, were downloaded from $\mathrm{NCBI}$ and used for mapping to recover partial or complete genomes.

\section{Viral RNA Sequencing}

Wet lab methods for RNA and sequencing

RNA Libraries were made using TruSeq Stranded Total RNA with RiboErase (Illumina, USA) sample preparation. Illumina's protocol was followed. Briefly, dependent on the extraction yield of RNA from CSF 1-100ng of RNA in 10ul were put into the prep, rRNA was depleted, cDNA and libraries were made and amplified for 15 cycles. The 130 libraries were pooled at $4 \mathrm{nM}$, loaded for sequencing per the manufacturer's protocol on the NovaSeq 6000 using the S2 2x100 flow cell.

PCR validation

Given the sensitivity limitations of both VirCapSeq and RNASeq for detection of virus, two qPCR assays were used to both confirm and screen for CMV in all of the preserved CSF and blood samples. For initial screening, a protocol previously described was used with a few 
medRxiv preprint doi: https://doi.org/10.1101/2020.08.03.20167544; this version posted August 4, 2020. The copyright holder for this preprint (which was not certified by peer review) is the author/funder, who has granted medRxiv a license to display the preprint in perpetuity.

All rights reserved. No reuse allowed without permission.

optimizations (86). The reverse primer gB4 was modified to 5'- GGTGGTTGCCCAACAGGATT3' due to off target human amplification and Quantitect SybrGreen Mastermix (Qiagen, USA) was used following manufacturers protocol for $10 \mu \mathrm{L}$ reaction volumes and $2 \mu \mathrm{L}$ DNA input with PCR and cycling conditions recommended by (87). A standard curve was generated from 10 million to 1 million copies using a full length clone DNA of Homo cytomegalovirus gB (Sino Biologicals, Beijing, China) (88, 89). For confirmation of the initial screening all samples were ran using a TaqMan assay previously described (90). A standard curve was generated using a gBlock Gene Fragment of the UL54 region (IDT, lowa, USA) from 10 million to 1 million copies. Technical replicates were evaluated in duplicate using each detection method. Samples were scored positive only if both replicates were positive in both assays.

PCR confirmation for human papilloma virus (HPV) was performed using the L1 Major Capsid Protein. HotStarTaq (Qiagen, Cat \# 203203) was used in $25 \mu$ l reactions following manufacturer's protocol with $0.5 \mu \mathrm{l}$ of $10 \mu \mathrm{M}$ primers and $5 \mu \mathrm{l}$ of DNA. For Sanger Sequencing, a 1x AMpure bead $p$ (Beckman Coulter Life Sciences) clean-up was performed eluting in $10 \mu \mathrm{l}$, mixed with forward and reverse primers then sent to Genewiz (NJ, USA). In the original PCR the product contained human sequences so nested PCR was performed as well using the same procedure in the first PCR reaction with a 1:10 dilution of the original PCR product. Sequencing was performed as well in the same manner. A positive HPV gBlock (IDT, USA) of the L1 major capsid protein gene diluted in human DNA was used as a positive control.

\section{Computational analysis and pipeline}

We established an internal pipeline to detect human viral-specific reads within RNA-sequencing data. For quality pre-processing, reads and tails below a Phred score of $30(91,92)$, reads shorter than $75 \mathrm{bp}$, and residual adapter sequences are filtered using Trimmomatic $(\mathrm{v} .0 .36,6)$ (93). Following pre-processing, unfiltered reads are aligned to hg38 with HISAT2 (v. 2.1.0) to eliminate any human-specific reads that may misalign to a manually curated virome reference database (84). Alignments are filtered by removing PCR duplicates, uniquely aligning reads (MAPQ score $=50$ ), and removing tandem repeats with Picard (MarkDuplicates, v. 2.18.16, 8), Bedtools (v. 2.17.0, 10), Samtools, and Tandem Repeat Finder (v. 4.09, 9) to eliminate library generation bias and sequencing artifacts (Picard Tools, Broad Institute, http://broadinstitute.github.io/picard/) $(94,95)$. Finally, the number of virus-specific reads per viral strain within each sample are aggregated into a count matrix for downstream analysis. 
medRxiv preprint doi: https://doi.org/10.1101/2020.08.03.20167544; this version posted August 4, 2020. The copyright holder for this preprint (which was not certified by peer review) is the author/funder, who has granted medRxiv a license to display the preprint in perpetuity.

All rights reserved. No reuse allowed without permission.

\section{Supplementary Figures}

\section{Supplementary Figure 1: CT Scans.}
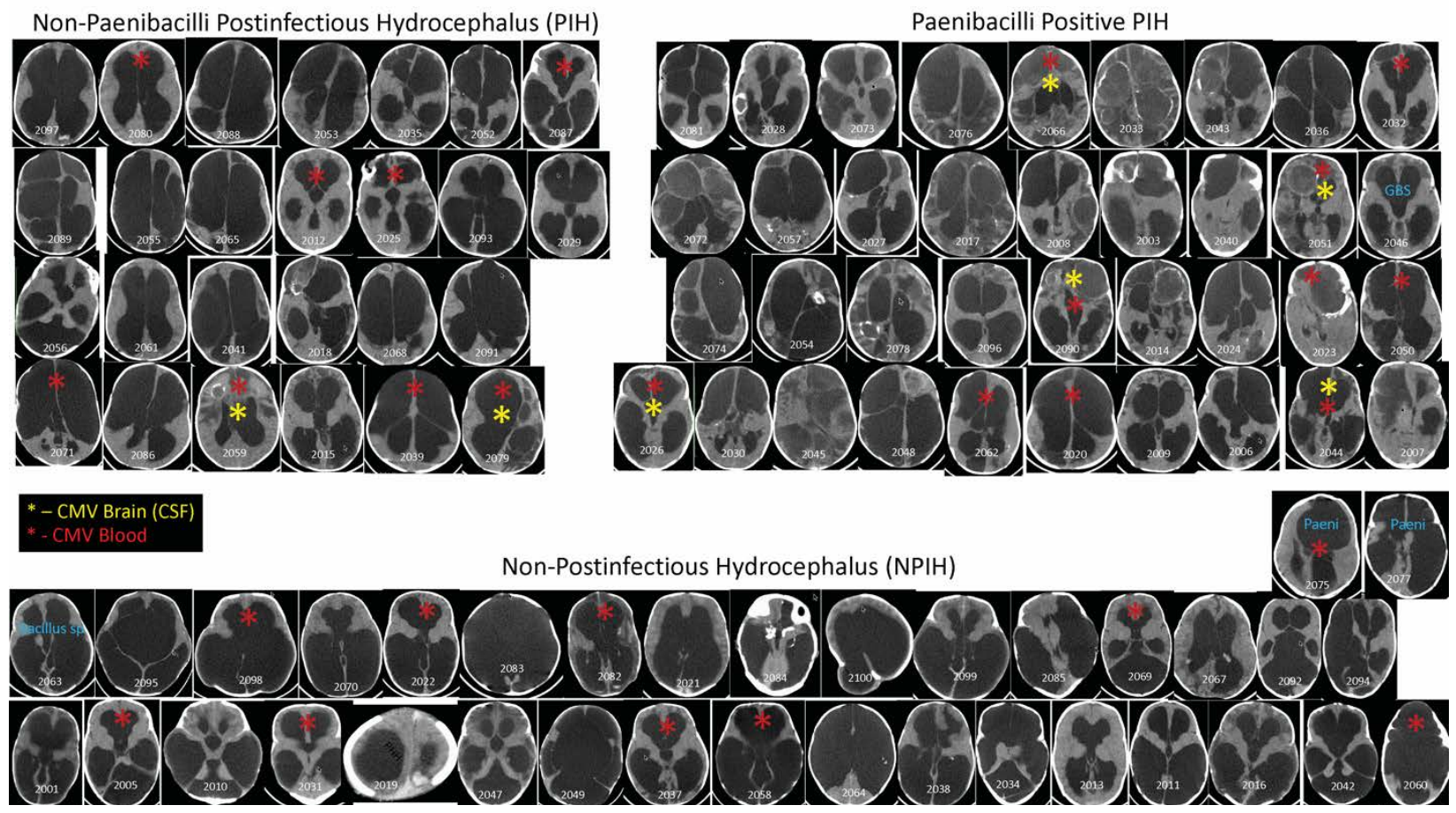

Supplementary Figure 1. Composite of CT scans from all patients grouped by postinfectious hydrocephalus (PIH, upper groupings) and non-postinfectious (NPIH, lower group)

hydrocephalus. The PIH group is further clustered by Paenibacillus negative (left) and positive (right). Yellow and red stars implicate if a patient was PCR positive for CMV in the CSF and blood respectively. Note that one PIH Paenibacillus positive patient (2002) has a missing CT scan. Two other patients met criteria for a bacterial identification for a putative pathogen, indicated as group B Streptococcus (GBS) in a case that was also Paenibacillus positive, and one case with Bacillus sp. in the NPIH group. Two patients in the NPIH group were positive for Paenibacilli (Paeni) using V1-V2 analysis. Note that no patient in the NPIH group that was CMV positive in the blood had CMV detected in the CSF. 
medRxiv preprint doi: https://doi.org/10.1101/2020.08.03.20167544; this version posted August 4, 2020. The copyright holder for this preprint (which was not certified by peer review) is the author/funder, who has granted medRxiv a license to display the preprint in perpetuity.

\section{Supplementary Figure 2: Spatial Statistics.}

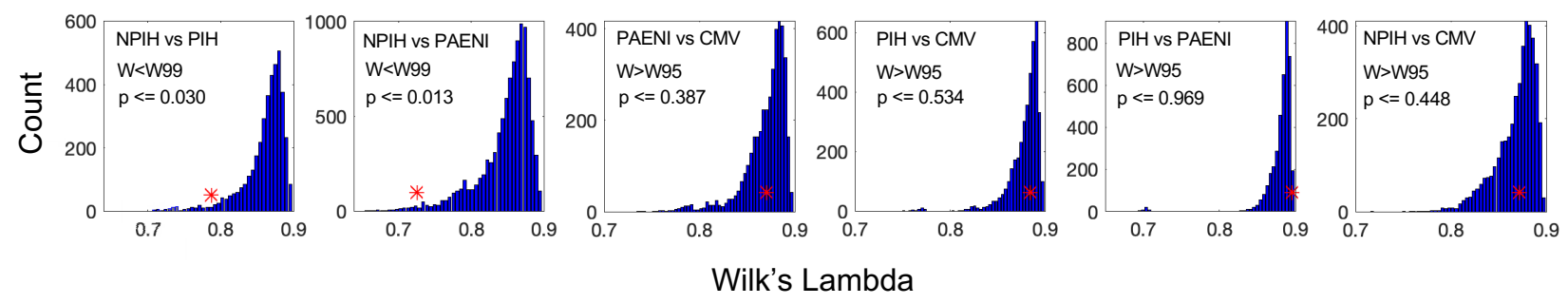

Supplementary Figure 2. Fisher's canonical linear discrimination (LDA) contrasting the location of the groupings of cases shown in Fig. 1. Shown are Wilk's lambda, W, reflecting the likelihood as the exponentiated sum of the log of the eigenvalues of the discriminant (96). W is chisquared distributed, and values smaller (greater) than the 95th or 99th percentile confidence limits (W95 or W99 respectively) are statistically significant (nonsignificant). To bootstrap the significance of the result, 10,000 random permutations of the group assignments into PIH vs NPIH were performed, and $W$ recalculated. The probability, $p$, that the $W$ of the LDA on the original unpermuted data was significantly different (smaller) than the permuted values is shown. The $\mathrm{W}$ from the data is shown as a red asterisk $\left(^{*}\right)$ on each histogram. 
medRxiv preprint doi: https://doi.org/10.1101/2020.08.03.20167544; this version posted August 4, 2020. The copyright holder for this preprint (which was not certified by peer review) is the author/funder, who has granted medRxiv a license to display the preprint in perpetuity.

\section{Supplementary Figure 3: Phylogenetic tree for 16S V1-V4 sequences}

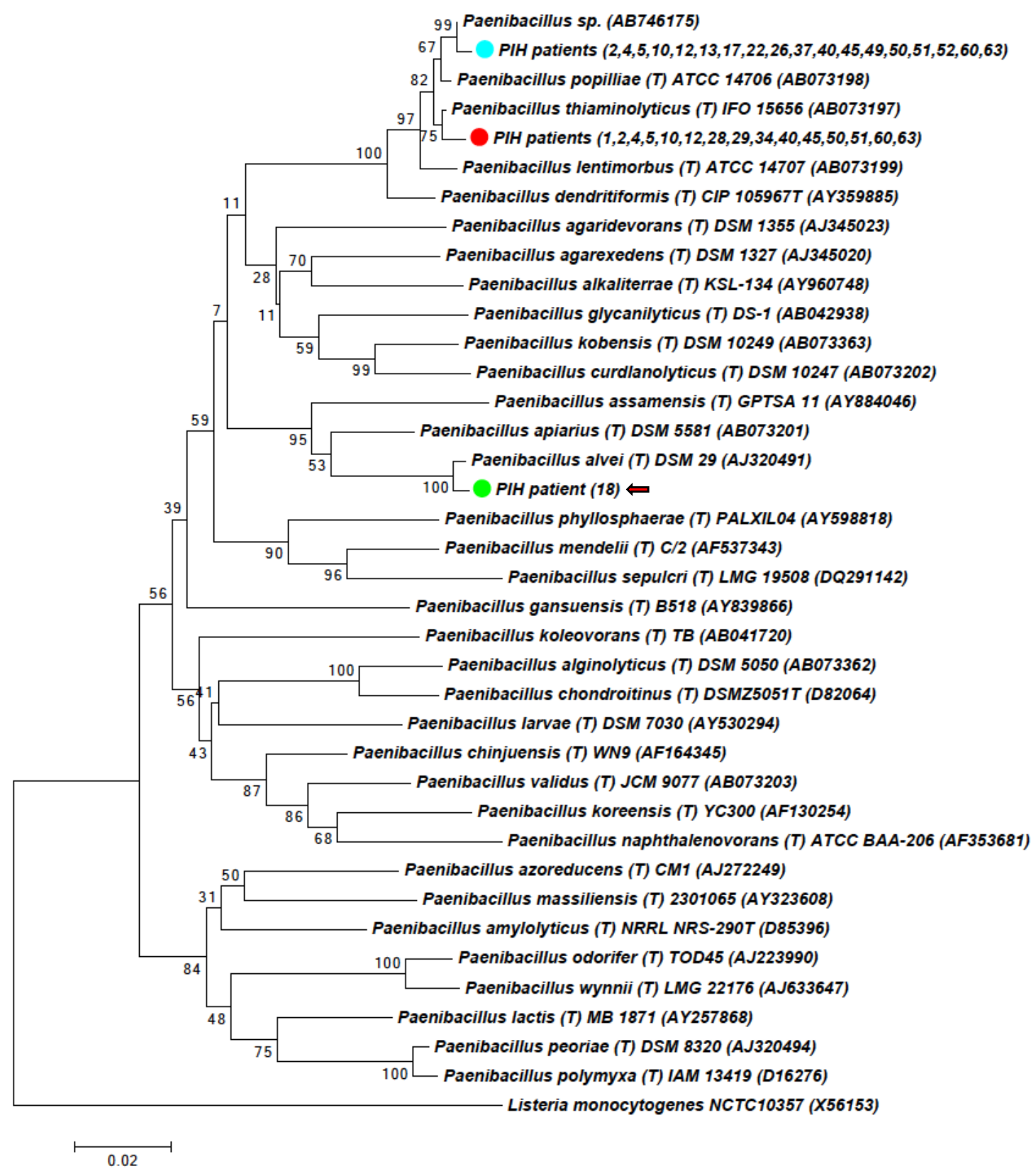

Supplementary Figure 3.

Phylogenetic tree for 16S V1-V4 sequences obtained from CSF of PIH patients (colored circles) and related isolates. The optimal evolutionary history was inferred using the Neighbor-Joining method (71). The percentage of replicate trees in which the associated taxa clustered together in the bootstrap test (500 replicates) are shown next to the branches (72). The tree is drawn to scale, with branch lengths in the same units as those of the evolutionary distances used to infer the phylogenetic tree. The evolutionary distances were computed using the Kimura 2-parameter method (73), and are in the units of the number of base substitutions per site. The analysis 
medRxiv preprint doi: https://doi.org/10.1101/2020.08.03.20167544; this version posted August 4, 2020. The copyright holder for this preprint (which was not certified by peer review) is the author/funder, who has granted medRxiv a license to display the preprint in perpetuity.

All rights reserved. No reuse allowed without permission.

involved 39 nucleotide sequences. All ambiguous positions were removed for each sequence pair. There were a total of 750 positions in the final dataset. 


\section{Supplementary Figure 4: Further analysis of the microbial 16S community}

A

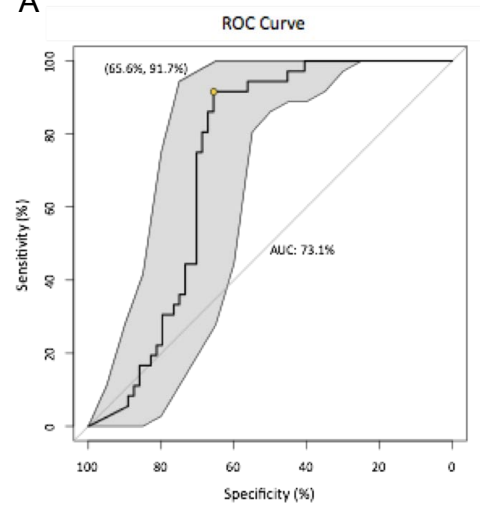

B

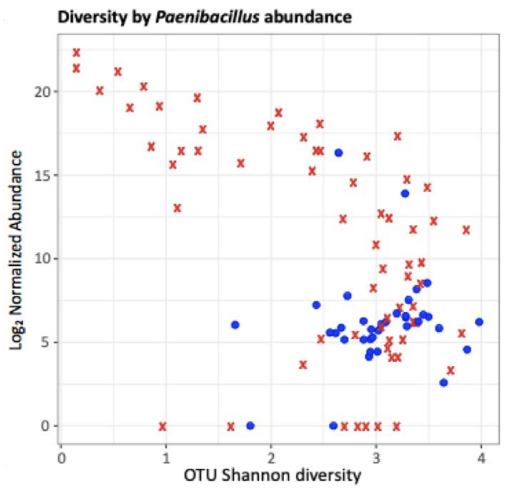

C

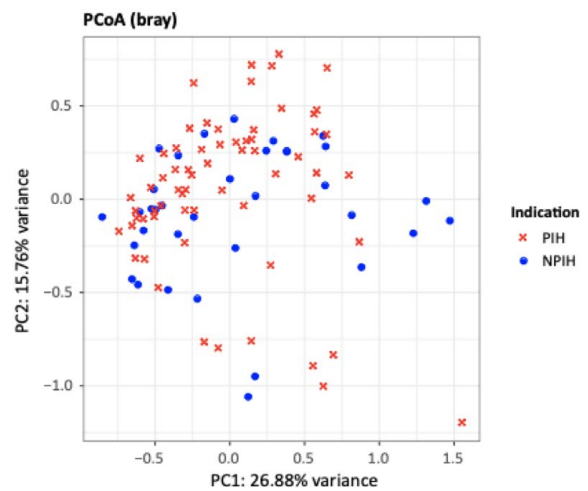

Supplementary Figure 4. Further analysis of the microbial 16S community. A) Receiveroperating-characteristic curve using Paenibacillus cumulative sum scaling (CSS) normalized abundance as the predictor for PIH or NPIH status. Area under the curve was $73.09 \%$ (95\% DeLong $\mathrm{Cl}=63.19 \%-82.99 \%$ ). B) Scatterplot of (y-axis) log2 normalized Paenibacillus $16 \mathrm{~S}$ abundance by (x-axis) Shannon diversity estimates. C) Classical multidimensional scaling on the Bray-Curtis distance matrix of $16 S$ abundances. 


\section{Supplementary Figure 5: OTU Heatmaps.}
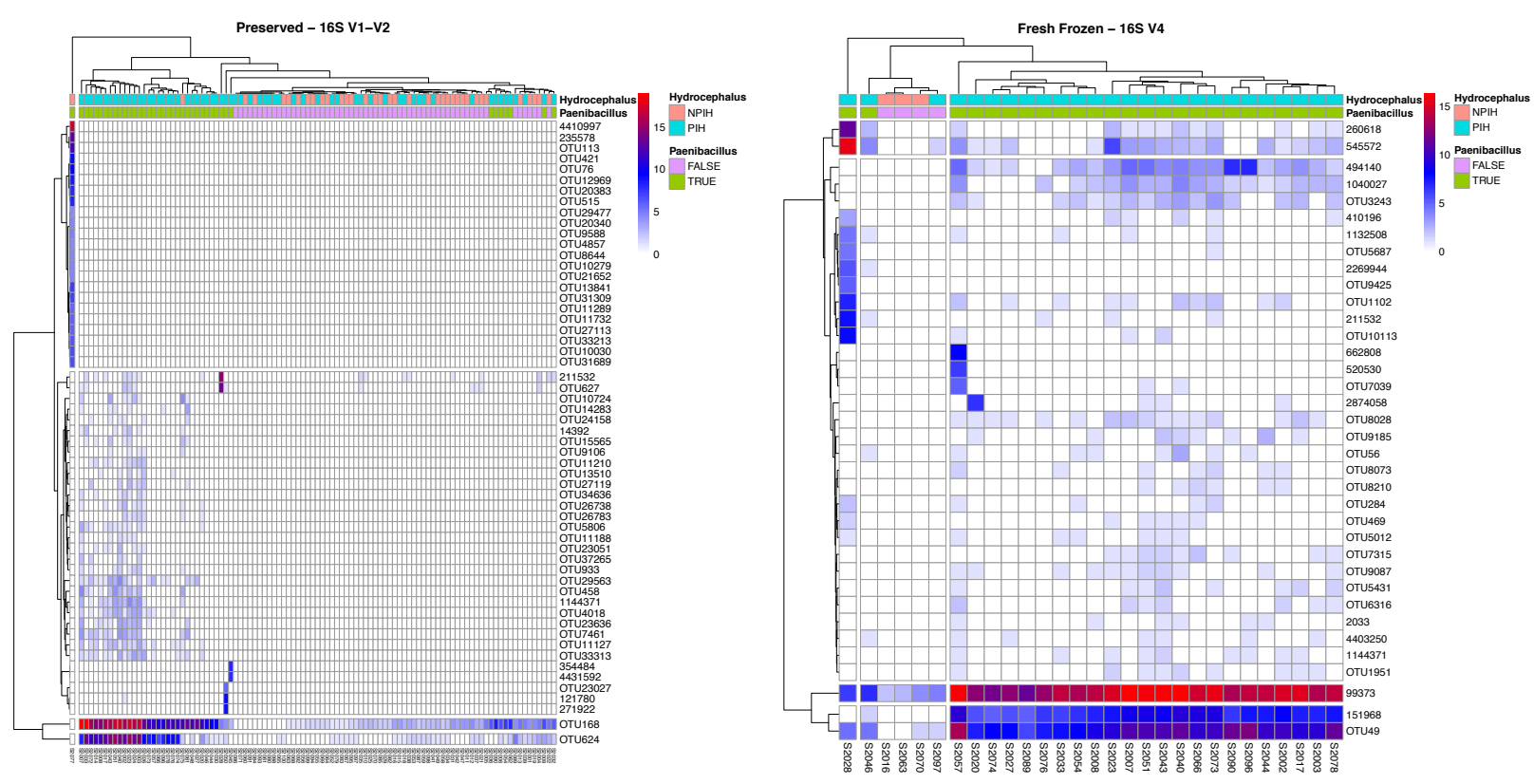

\section{Supplementary Figure 5.}

Log-transformed number of reads for each Operational Taxonomic Unit (OTU) annotated to the Paenibacillus genus. OTUs were subset to only those annotated to the Paenibacillus genus. The columns represent samples with hydrocephalus status (PIH/NPIH) and Paenibacillus positivity as defined by at least 50 reads within the respective dataset. Both the V1-V2 (left) and V4 (right) 16S sequencing have two dominant OTU sequence centers that are most represented among the positive Paenibacillus (green) patients with the exception of an NPIH positive case that clusters separately in the V1-V2 sequencing cohort. These OTU centers have high sequence similarity to the $P$. thiaminolyticus Mbale clinical isolate while not having sequence similarity $\geq 97 \%$ to the other two Paenibacillus isolates. Specifically, the two most abundant OTU sequence centers in V4, 99373 and 151968, align at $100 \%$ and $99.6 \%$ respectively along with three other less abundant but present centers OTUs 545572, 1144371, and 494140 that align at $>99 \%$. For V1-V2, OTU 168 and 624 dominate the signal and align to the clinical isolate at $100 \%$ and $97 \%$ respectively. 
Supplementary Figure 6: qPCR vs Age, CT Score, and Cell Counts.

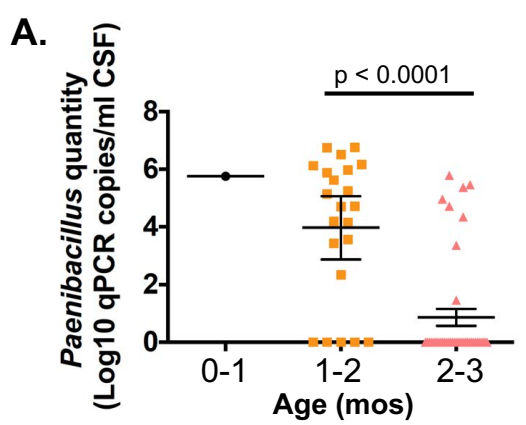

D.

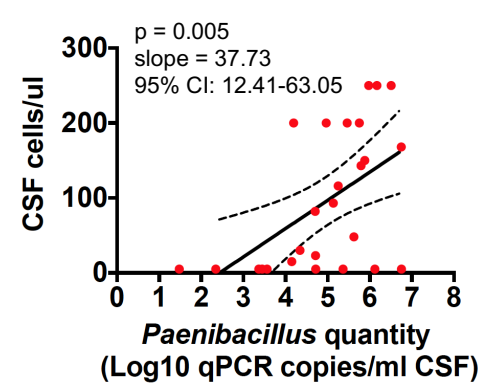

B.

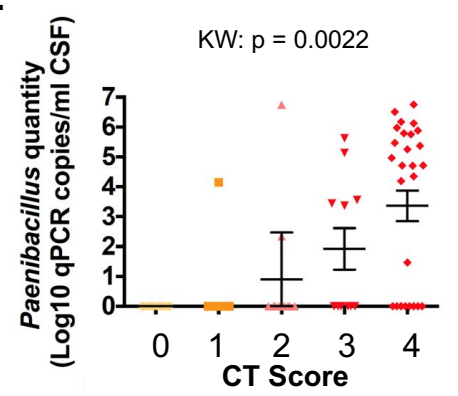

E.

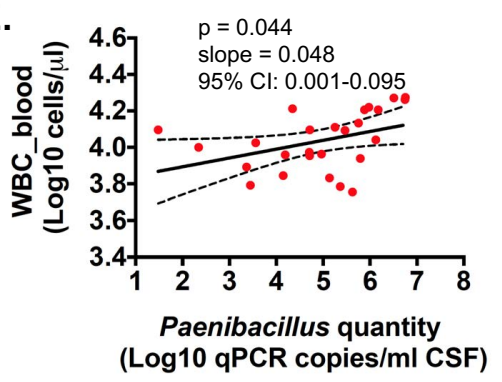

C.

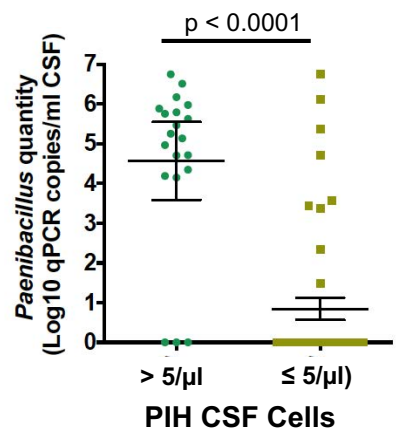

Supplementary Figure 6.. Distribution of Paenibacillus quantity as determined by qPCR in CSF by age $(\mathbf{A})$ and CT score (B). Quantity of Paenibacillus in CSF from PIH patients with $>5$ cells $/ \mu \mathrm{l}$ CSF compared to PIH patients with $\leq 5 \mathrm{cells} / \mu \mathrm{l}$ CSF $(\mathbf{C})$. Relationship between Paenibacillus quantity in CSF and CSF cell counts (cells/ $\mu \mathrm{l})$ in $\mathrm{PIH}$ patients with quantifiable Paenibacillus by qPCR (D). Relationship between Paenibacillus quantity in CSF and WBC counts in blood (cells/ $\mu \mathrm{l}$ ) in PIH patients with quantifiable Paenibacillus by qPCR (E). The linear regression line estimated by a univariate model for CSF cells (D) or WBC counts (E) with Paenibacillus quantity as the primary covariate is shown (solid line in $\mathbf{D}, \mathbf{E}$ ). p-values shown were derived from the Mann-Whitney $U$ test $(\mathbf{A}, \mathbf{C})$, the Kruskal-Wallace test $(\mathbf{B})$ and univariate linear regression (D, E). The estimated increase in CSF cells or WBC counts for one log10 fold increase in Paenibacillus quantity and associated $95 \% \mathrm{Cl}$ is indicated (slope and $95 \% \mathrm{Cl}, \mathbf{D}$ and $\mathbf{E}$ ). 
Supplementary Figure 7: CT Score Frequencies.

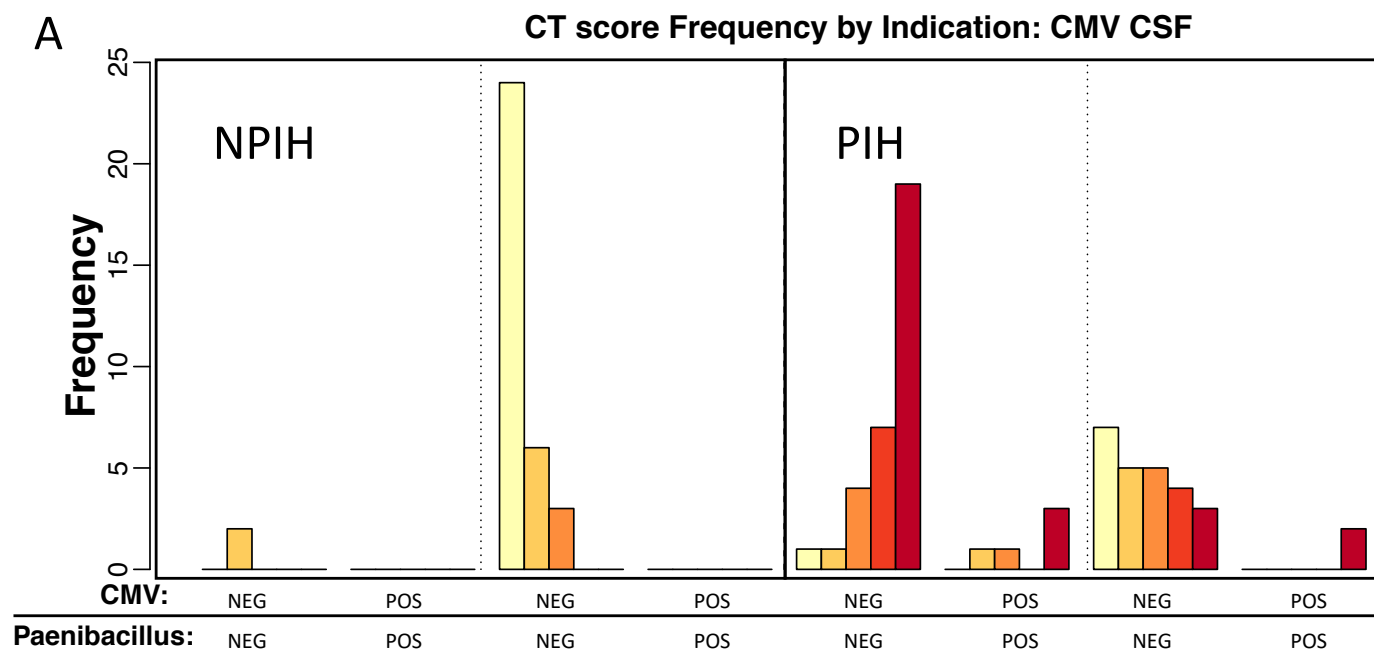

CT Score

$\square 0$

$\square 1$

$\square 2$

$\square 3$

$\square 4$

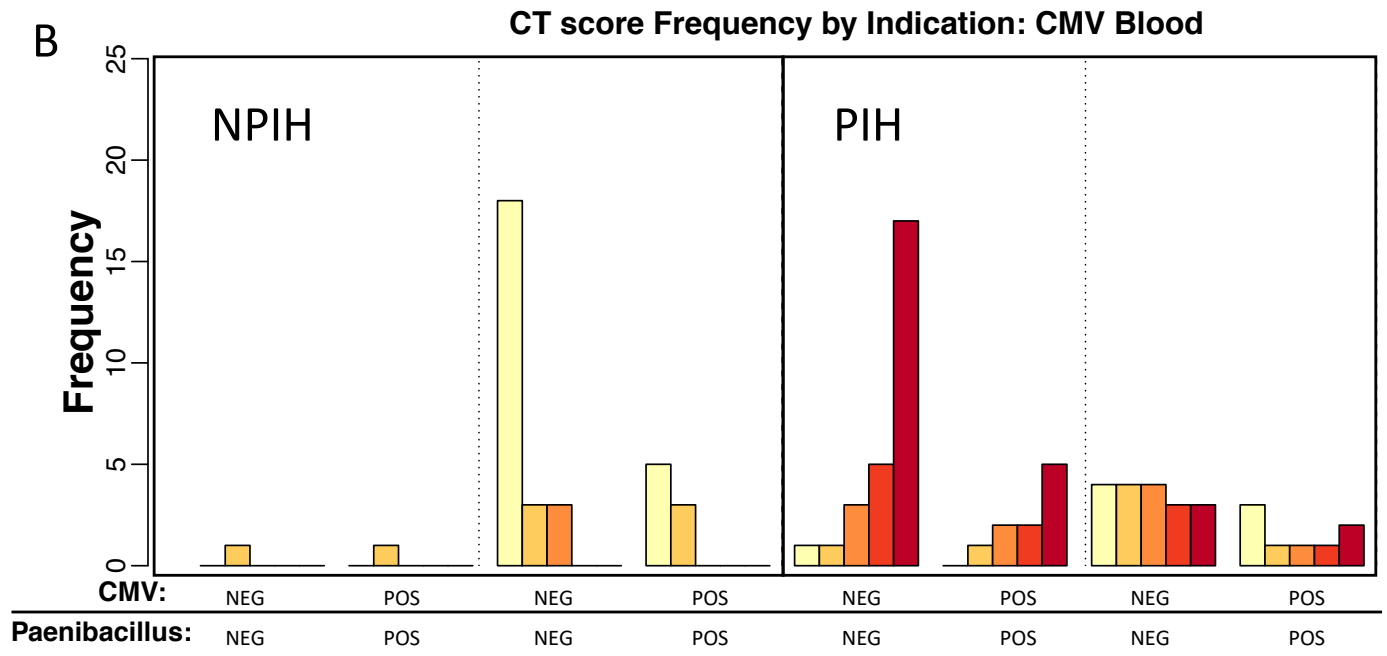

Supplementary Figure 7. A) CT scores as a function of CMV infection status, positive or negative, in CSF. CT score status further stratified by clinical indication, $\mathrm{PIH}$ or $\mathrm{NPIH}$, and whether CSF 16 S sequencing was positive for $P$. thiaminolyticus, and whether CMV was positive or negative in CSF. B) CT scores as a function of CMV infection status, positive or negative, in blood. CT score status further stratified by clinical indication, $\mathrm{PIH}$ or $\mathrm{NPIH}$, and whether CSF 16 S sequencing was positive for $P$. thiaminolyticus, and whether CMV was positive or negative in blood. 


\section{Supplementary Tables}

Supplementary Table 1: Primer Table.

\begin{tabular}{|c|c|c|c|c|c|}
\hline Organism & Target & Primer & Sequence & $\begin{array}{l}\text { Nucleic } \\
\text { Acid }\end{array}$ & Publication \\
\hline \multirow[t]{2}{*}{ Plasmodium } & \multirow[t]{2}{*}{$18 S$} & Plasmo 1 & $\begin{array}{l}\text { GTTAAGGGA } \\
\text { GTGAAGACG } \\
\text { A TCAGA }\end{array}$ & \multirow[t]{2}{*}{ DNA } & \multirow[t]{2}{*}{ (97) } \\
\hline & & Plasmo 2 & $\begin{array}{l}\text { AACCCAAAG } \\
\text { ACTTTGATTT } \\
\text { CTCATAA }\end{array}$ & & \\
\hline \multirow[t]{3}{*}{ Plasmodium } & \multirow[t]{3}{*}{$18 \mathrm{~S}$} & PlasF & $\begin{array}{l}\text { TTTCTGACC } \\
\text { TATCAGCTT } \\
\text { TTGATGTT }\end{array}$ & \multirow[t]{3}{*}{ RNA } & \multirow[t]{3}{*}{ Unpublished } \\
\hline & & PlasR & $\begin{array}{l}\text { GCTCCCTCT } \\
\text { CCGGAATCG }\end{array}$ & & \\
\hline & & PlasProbe & $\begin{array}{l}\text { CTAACATGG } \\
\text { CTATGACGG } \\
\text { GT }\end{array}$ & & \\
\hline \multirow[t]{2}{*}{ Toxoplasmosis } & \multirow[t]{2}{*}{ B1 gene } & $\begin{array}{l}\text { Toxo } \\
\text { Oligo } 2\end{array}$ & $\begin{array}{l}\text { TAATACGAC } \\
\text { TCACTATAG } \\
\text { GGTGCATAG } \\
\text { GTTGCAGT } \\
\text { CACTG }\end{array}$ & \multirow[t]{2}{*}{ DNA } & \multirow[t]{2}{*}{$(98)$} \\
\hline & & $\begin{array}{l}\text { Toxo } \\
\text { Oligo } 4\end{array}$ & $\begin{array}{l}\text { TCTT } \\
\text { TAAAGCGTT } \\
\text { CGTGGTC }\end{array}$ & & \\
\hline \multirow[t]{2}{*}{$\begin{array}{l}\text { Trypanosoma } \\
\text { brucei }\end{array}$} & \multirow[t]{2}{*}{$\begin{array}{l}\text { Expression } \\
\text { site } \\
\text { associated } \\
\text { protein-6 }\end{array}$} & ESAGF1 & $\begin{array}{l}\text { GCGTTAGCA } \\
\text { GCAGCTGCA } \\
\text { GCTGGG }\end{array}$ & \multirow[t]{2}{*}{$\begin{array}{l}\text { RNA and } \\
\text { DNA }\end{array}$} & \multirow[t]{2}{*}{ (99) } \\
\hline & & mycR & $\begin{array}{l}\text { CCCAAGTCC } \\
\text { TCTTCAGAA } \\
\text { ATGAGC }\end{array}$ & & \\
\hline
\end{tabular}


medRxiv preprint doi: https://doi.org/10.1101/2020.08.03.20167544; this version posted August 4, 2020. The copyright holder for this preprint (which was not certified by peer review) is the author/funder, who has granted medRxiv a license to display the preprint in perpetuity. All rights reserved. No reuse allowed without permission.

\begin{tabular}{|c|c|c|c|c|c|}
\hline \multirow[t]{2}{*}{$\begin{array}{l}\text { Trypanosoma } \\
\text { cruzi }\end{array}$} & \multirow{2}{*}{$\begin{array}{l}\text { Major } \\
\text { repetitive } \\
\text { element }\end{array}$} & TCZ1 & $\begin{array}{l}\text { dCGAGCTCT } \\
\text { TGCCCACAC } \\
\text { GGGTGCT }\end{array}$ & \multirow[t]{2}{*}{ DNA } & \multirow[t]{2}{*}{$(100)$} \\
\hline & & TCZ2 & $\begin{array}{l}\text { dCCTCCAAG } \\
\text { CAGCGGATA } \\
\text { GTTCAGG }\end{array}$ & & \\
\hline \multirow[t]{3}{*}{$\begin{array}{l}\text { Salmonella } \\
\text { typhi }\end{array}$} & \multirow[t]{3}{*}{$\begin{array}{l}\text { Flagella } \\
\text { gene }\end{array}$} & StyphiF & $\begin{array}{l}\text { ACCATCGGG } \\
\text { CTTTAAGGT } \\
\text { TGCC }\end{array}$ & \multirow[t]{3}{*}{ RNA } & \multirow[t]{3}{*}{ Unpublished } \\
\hline & & StyphiR & $\begin{array}{l}\text { GCGCCCAGA } \\
\text { TGGTACTCA } \\
\text { AACC }\end{array}$ & & \\
\hline & & $\begin{array}{l}\text { StyphiPro } \\
\text { be }\end{array}$ & $\begin{array}{l}\text { TCGCGCTTC } \\
\text { CTACCGGGC } \\
T\end{array}$ & & \\
\hline \multirow[t]{2}{*}{ Parvovirus B19 } & \multirow[t]{2}{*}{ NS1 } & $\begin{array}{l}\text { Parvo- } \\
\text { NS1-F }\end{array}$ & $\begin{array}{l}\text { TAGTGGTGG } \\
\text { TGAAAGCTC } \\
\text { TGA }\end{array}$ & \multirow[t]{2}{*}{ RNA } & \multirow[t]{2}{*}{ Unpublished } \\
\hline & & $\begin{array}{l}\text { Parvo- } \\
\text { NS1-R }\end{array}$ & $\begin{array}{l}\text { TCCGACAGA } \\
\text { TGATTCTCC } \\
\text { TGA }\end{array}$ & & \\
\hline \multirow[t]{2}{*}{ Enterovirus } & \multirow[t]{2}{*}{ 5'UTR } & $\begin{array}{l}\text { Hiro-UTR- } \\
\text { fwd-1 }\end{array}$ & $\begin{array}{l}\text { GGTCAAGCA } \\
\text { CTTCTGTTT } \\
\text { CCC }\end{array}$ & \multirow[t]{2}{*}{ RNA } & Unpublished \\
\hline & & $\begin{array}{l}\text { EV-UTR- } \\
\text { L541 }\end{array}$ & $\begin{array}{l}\text { GAAACACGG } \\
\text { WCACCCAAA } \\
\text { GTASTCG }\end{array}$ & & Unpublished \\
\hline \multirow[t]{2}{*}{$\begin{array}{l}\text { Human } \\
\text { Papilloma Virus }\end{array}$} & \multirow[t]{2}{*}{$\begin{array}{l}\text { Major } \\
\text { Capsid } \\
\text { Protein L1 }\end{array}$} & $\begin{array}{l}\text { RT-HPV- } \\
5034-F\end{array}$ & $\begin{array}{l}\text { GTAGCACTC } \\
\text { CCAATGAAA } \\
\text { GGTC }\end{array}$ & \multirow[t]{2}{*}{ DNA } & \multirow[t]{2}{*}{ Unpublished } \\
\hline & & $\begin{array}{l}\text { RT-HPV- } \\
5251-R\end{array}$ & $\begin{array}{l}\text { GTCTCTGTC } \\
\text { TGGAGGSTC } \\
\text { TTCA }\end{array}$ & & \\
\hline
\end{tabular}


medRxiv preprint doi: https://doi.org/10.1101/2020.08.03.20167544; this version posted August 4, 2020. The copyright holder for this preprint (which was not certified by peer review) is the author/funder, who has granted medRxiv a license to display the preprint in perpetuity. All rights reserved. No reuse allowed without permission.

\begin{tabular}{|c|c|c|c|c|c|}
\hline \multirow[t]{2}{*}{$\begin{array}{l}\text { Human } \\
\text { Papilloma Virus }\end{array}$} & \multirow[t]{2}{*}{$\begin{array}{l}\text { Major } \\
\text { Capsid } \\
\text { Protein L1 }\end{array}$} & $\begin{array}{l}\text { MCP- } \\
\text { Nested- } \\
\text { Fwd }\end{array}$ & $\begin{array}{l}\text { CGGTCATTA } \\
\text { ACCAATAGA } \\
\text { CG }\end{array}$ & \multirow[t]{2}{*}{ DNA } & \multirow[t]{2}{*}{ Unpublished } \\
\hline & & $\begin{array}{l}\text { MCP- } \\
\text { Nested- } \\
\text { Rev }\end{array}$ & $\begin{array}{l}\text { AAATCTTAC } \\
\text { CAATCTAGA } \\
\text { GGGCTG }\end{array}$ & & \\
\hline \multirow[t]{3}{*}{$\begin{array}{l}\text { Human Herpes } \\
\text { Virus } 5 \text { (CMV) }\end{array}$} & \multirow[t]{3}{*}{ UL54 } & $\begin{array}{l}\text { CPOL- } \\
\text { F720 }\end{array}$ & $\begin{array}{l}\text { GCTGACGCG } \\
\text { TTTGGTCAT } \\
\text { C }\end{array}$ & \multirow[t]{3}{*}{ DNA } & \multirow[t]{3}{*}{$(90)$} \\
\hline & & $\begin{array}{l}\text { CPOL- } \\
\text { R780 }\end{array}$ & $\begin{array}{l}\text { ACGATT CAC } \\
\text { GGA GCA } \\
\text { CCAG }\end{array}$ & & \\
\hline & & $\begin{array}{l}\text { CPOL- } \\
\text { 741FAM }\end{array}$ & $\begin{array}{l}\text { TCGGCGGAT } \\
\text { CACCACGTT } \\
\text { CG }\end{array}$ & & \\
\hline \multirow[t]{2}{*}{$\begin{array}{l}\text { Human Herpes } \\
\text { Virus } 5 \text { (CMV) }\end{array}$} & \multirow[t]{2}{*}{ UL55 } & gB2 & $\begin{array}{l}\text { ACGACCCGT } \\
\text { GGTCATCTT } \\
\text { TA }\end{array}$ & \multirow[t]{2}{*}{ DNA } & \multirow[t]{2}{*}{$(86)$} \\
\hline & & $\begin{array}{l}\text { gB4- } \\
\text { modified }\end{array}$ & $\begin{array}{l}\text { GGTGGTTGC } \\
\text { CCAACAGGA } \\
\text { TT }\end{array}$ & & \\
\hline \multirow[t]{3}{*}{$\begin{array}{l}\text { Paenibacillus } \\
\text { spp. }\end{array}$} & \multirow[t]{3}{*}{$16 S$} & PaeniF & $\begin{array}{l}\text { CAGGGAAGA } \\
\text { ACGCTATGG } \\
\text { A }\end{array}$ & \multirow[t]{3}{*}{ DNA } & \multirow[t]{3}{*}{$(101)$} \\
\hline & & PaeniR & $\begin{array}{l}\text { CGATGCGAC } \\
\text { CCGGAGTT }\end{array}$ & & \\
\hline & & $\begin{array}{l}\text { PaeniProb } \\
\text { e }\end{array}$ & $\begin{array}{l}\text { FAM- } \\
\text { TGTTCCATA } \\
\text { GGTGACGGT } \\
\text { ACCT-MGB }\end{array}$ & & \\
\hline \multirow[t]{2}{*}{ Prokaryotes } & \multirow[t]{2}{*}{$\begin{array}{l}\text { V1-V4 16S } \\
\text { rRNA }\end{array}$} & $27 \mathrm{~F} .1$ & $\begin{array}{l}\text { AGRGTTTGA } \\
\text { TCMTGGCTC } \\
\text { AG }\end{array}$ & \multirow[t]{2}{*}{ DNA } & $(102)$ \\
\hline & & $805 R$ & $\begin{array}{l}\text { GACTACCAG } \\
\text { GGTATCTAA } \\
\mathrm{T}\end{array}$ & & (103) \\
\hline
\end{tabular}


medRxiv preprint doi: https://doi.org/10.1101/2020.08.03.20167544; this version posted August 4, 2020. The copyright holder for this preprint (which was not certified by peer review) is the author/funder, who has granted medRxiv a license to display the preprint in perpetuity. All rights reserved. No reuse allowed without permission.

\begin{tabular}{|c|c|c|c|c|c|}
\hline \multirow[t]{3}{*}{ Prokaryotes } & \multirow[t]{3}{*}{$\begin{array}{l}\text { V1-V2 16S } \\
\text { rRNA }\end{array}$} & $27 \mathrm{~F}$ & $\begin{array}{l}\text { AGAGTTTGA } \\
\text { TCMTGGCTC } \\
\text { AG }\end{array}$ & \multirow[t]{3}{*}{ DNA } & (104) \\
\hline & & $\begin{array}{l}\text { 336R_M1 } \\
3\end{array}$ & $\begin{array}{l}\text { CAGGGTTTT } \\
\text { CCCAGTCAC } \\
\text { GACACTGCT } \\
\text { GCSYCCCGT } \\
\text { AGGAGTCT }\end{array}$ & & (105) (modified) \\
\hline & & M13 & $\begin{array}{l}\text { CAGGGTTTT } \\
\text { CCCAGTCAC } \\
\text { GAC }\end{array}$ & & na \\
\hline \multirow[t]{2}{*}{ Prokaryotes } & \multirow[t]{2}{*}{$\begin{array}{l}\text { V4 16S } \\
\text { rRNA }\end{array}$} & $515 \mathrm{~F}$ & $\begin{array}{l}\text { AATGATACG } \\
\text { GCGACCACC } \\
\text { GAGATCTAC } \\
\text { ACTATGGTA } \\
\text { ATTGTGTGC } \\
\text { CAGCMGCC } \\
\text { GCGGTAA }\end{array}$ & \multirow[t]{2}{*}{ DNA } & (56) \\
\hline & & $806 \mathrm{R}$ & $\begin{array}{l}\text { CAAGCAGAA } \\
\text { GACGGCATA } \\
\text { CGAGATXXX } \\
\text { XXXXXXXXX } \\
\text { AGTCAGTCA } \\
\text { GCCGGACTA } \\
\text { CHVGGGTW } \\
\text { TCTAAT }\end{array}$ & & $(56)$ \\
\hline \multirow[t]{2}{*}{ Fungi } & \multirow[t]{2}{*}{ ITS2 } & ITS3F & $\begin{array}{l}\text { GCATCGATG } \\
\text { AAGAACGCA } \\
\text { GC }\end{array}$ & \multirow[t]{2}{*}{ DNA } & \multirow[t]{2}{*}{ (104) } \\
\hline & & ITS4R & $\begin{array}{l}\text { TCCTCCGCT } \\
\text { TATTGATAT } \\
\text { GC }\end{array}$ & & \\
\hline
\end{tabular}

Supplementary Table 1. Primer table for all PCR to identify microbiological DNA or RNA present in the CSF or Blood. 
medRxiv preprint doi: https://doi.org/10.1101/2020.08.03.20167544; this version posted August 4, 2020. The copyright holder for this preprint (which was not certified by peer review) is the author/funder, who has granted medRxiv a license to display the preprint in perpetuity.

All rights reserved. No reuse allowed without permission.

Supplementary Table 2: Fresh Frozen PCR and Sequencing. 


\begin{tabular}{|c|c|c|c|c|c|c|}
\hline $\begin{array}{l}\text { Sample } \\
\text { Number }\end{array}$ & Group & $\begin{array}{c}\text { CPCR 16S } \\
\text { V1-V4 } \\
\text { amplification }\end{array}$ & $\begin{array}{c}\text { cPCR 16S V1-V4 } \\
\text { (Cloning/Sequencing } \\
\text { Results) }\end{array}$ & $\begin{array}{c}\text { Paenibacillus } \\
\text { genus-specific } \\
\text { qPCR (16S } \\
\text { copies/mL } \\
\text { CSF) } \\
\end{array}$ & $\begin{array}{c}\text { V4 MiSeq } \\
\text { (Dominant taxa) }\end{array}$ & $\begin{array}{c}\text { Assay } \\
\text { Concordance } \\
\text { (\# Assays } \\
\text { demonstrating } \\
\text { Paenibacillus) }\end{array}$ \\
\hline 2002 & $\mathrm{PIH}$ & Positive & $\begin{array}{c}\text { Paenibacillus } \\
\text { thiaminolyticus or } \\
\text { popilliae }\end{array}$ & $2.33 E+05$ & Paenibacillus sp. & 3 \\
\hline 2003 & $\mathrm{PIH}$ & Positive & $\begin{array}{c}\text { Paenibacillus } \\
\text { thiaminolyticus or } \\
\text { popilliae }\end{array}$ & $5.07 E+04$ & Paenibacillus sp. & 3 \\
\hline 2006 & $\mathrm{PIH}$ & Negative & no amplification & 0 & no amplification & 0 \\
\hline 2007 & $\mathrm{PIH}$ & Positive & $\begin{array}{c}\text { Paenibacillus } \\
\text { thiaminolyticus or } \\
\text { popilliae }\end{array}$ & $5.59 \mathrm{E}+06$ & Paenibacillus sp. & 3 \\
\hline 2008 & $\mathrm{PIH}$ & Positive & $\begin{array}{c}\text { Paenibacillus } \\
\text { thiaminolyticus or } \\
\text { popilliae }\end{array}$ & $1.79 \mathrm{E}+05$ & Paenibacillus sp. & 3 \\
\hline 2009 & $\mathrm{PIH}$ & Negative & no amplification & 0 & no amplification & 0 \\
\hline 2012 & $\mathrm{PIH}$ & Negative & no amplification & 0 & no amplification & 0 \\
\hline 2014 & $\mathrm{PIH}$ & Negative & no amplification & 0 & no amplification & 0 \\
\hline 2015 & $\mathrm{PIH}$ & Negative & no amplification & 0 & no amplification & 0 \\
\hline 2017 & $\mathrm{PIH}$ & Positive & $\begin{array}{c}\text { Paenibacillus } \\
\text { thiaminolyticus or } \\
\text { popilliae }\end{array}$ & $1.49 \mathrm{E}+06$ & Paenibacillus sp. & 3 \\
\hline 2018 & $\mathrm{PIH}$ & Negative & no amplification & 0 & no amplification & 0 \\
\hline 2020 & $\mathrm{PIH}$ & Positive & $\begin{array}{c}\text { Paenibacillus } \\
\text { thiaminolyticus or } \\
\text { popilliae }\end{array}$ & $3.63 \mathrm{E}+03$ & Paenibacillus sp. & 3 \\
\hline 2023 & $\mathrm{PIH}$ & Positive & $\begin{array}{c}\text { Paenibacillus } \\
\text { thiaminolyticus or } \\
\text { popilliae }\end{array}$ & $3.23 E+06$ & Paenibacillus sp. & 3 \\
\hline 2024 & $\mathrm{PIH}$ & Negative & no amplification & 0 & no amplification & 0 \\
\hline 2025 & $\mathrm{PIH}$ & Negative & no amplification & 0 & no amplification & 0 \\
\hline 2026 & $\mathrm{PIH}$ & Negative & no amplification & $1.41 \mathrm{E}+04$ & no amplification & 1 \\
\hline 2027 & $\mathrm{PIH}$ & Positive & $\begin{array}{c}\text { Paenibacillus } \\
\text { thiaminolyticus or } \\
\text { popilliae }\end{array}$ & $5.16 \mathrm{E}+04$ & Paenibacillus sp. & 3 \\
\hline 2028 & $\mathrm{PIH}$ & Positive & Paenibacillus alvei & $0^{*}$ & $\begin{array}{c}\text { Paenibacillus } \\
\text { alvei }\end{array}$ & 2 \\
\hline 2029 & $\mathrm{PIH}$ & Negative & no amplification & 0 & no amplification & 0 \\
\hline 2030 & $\mathrm{PIH}$ & Negative & no amplification & 0 & no amplification & 0 \\
\hline 2032 & $\mathrm{PIH}$ & Negative & no amplification & 0 & no amplification & 0 \\
\hline 2033 & $\mathrm{PIH}$ & Positive & $\begin{array}{c}\text { Paenibacillus } \\
\text { thiaminolyticus or } \\
\text { popilliae }\end{array}$ & $5.67 \mathrm{E}+05$ & Paenibacillus sp. & 3 \\
\hline 2035 & $\mathrm{PIH}$ & Negative & no amplification & 0 & no amplification & 0 \\
\hline 2036 & $\mathrm{PIH}$ & Negative & no amplification & 0 & no amplification & 0 \\
\hline
\end{tabular}




\begin{tabular}{|c|c|c|c|c|c|c|}
\hline 2039 & $\mathrm{PIH}$ & Negative & no amplification & 0 & no amplification & 0 \\
\hline 2040 & $\mathrm{PIH}$ & Positive & $\begin{array}{c}\text { Paenibacillus } \\
\text { thiaminolyticus or } \\
\text { popilliae }\end{array}$ & $4.23 E+05$ & Paenibacillus sp. & 3 \\
\hline 2041 & $\mathrm{PIH}$ & Negative & no amplification & 0 & no amplification & 0 \\
\hline 2043 & $\mathrm{PIH}$ & Positive & $\begin{array}{c}\text { Paenibacillus } \\
\text { thiaminolyticus or } \\
\text { popilliae }\end{array}$ & $5.68 \mathrm{E}+06$ & Paenibacillus sp. & 3 \\
\hline 2044 & $\mathrm{PIH}$ & Positive & $\begin{array}{c}\text { Paenibacillus } \\
\text { thiaminolyticus or } \\
\text { popilliae }\end{array}$ & $2.20 E+02$ & Paenibacillus sp. & 3 \\
\hline 2045 & $\mathrm{PIH}$ & Negative & no amplification & 0 & no amplification & 0 \\
\hline 2046 & $\mathrm{PIH}$ & Positive & $\begin{array}{c}\text { Streptococcus } \\
\text { agalactiae }\end{array}$ & 0 & $\begin{array}{c}\text { Streptococcus } \\
\text { sp. }\end{array}$ & 0 \\
\hline 2048 & $\mathrm{PIH}$ & Negative & no amplification & $2.91 \mathrm{E}+01$ & no amplification & 1 \\
\hline 2050 & $\mathrm{PIH}$ & Positive & Alkanindiges sp. & 0 & no amplification & 0 \\
\hline 2051 & $\mathrm{PIH}$ & Positive & $\begin{array}{c}\text { Paenibacillus } \\
\text { thiaminolyticus or } \\
\text { popilliae }\end{array}$ & $1.33 E+06$ & Paenibacillus sp. & 3 \\
\hline 2052 & $\mathrm{PIH}$ & Negative & no amplification & 0 & no amplification & 0 \\
\hline 2053 & $\mathrm{PIH}$ & Negative & no amplification & 0 & no amplification & 0 \\
\hline 2054 & $\mathrm{PIH}$ & Positive & $\begin{array}{c}\text { Paenibacillus } \\
\text { thiaminolyticus or } \\
\text { popilliae }\end{array}$ & $5.22 \mathrm{E}+04$ & Paenibacillus sp. & 3 \\
\hline 2055 & $\mathrm{PIH}$ & Negative & no amplification & 0 & no amplification & 0 \\
\hline 2056 & $\mathrm{PIH}$ & Negative & no amplification & 0 & no amplification & 0 \\
\hline 2057 & $\mathrm{PIH}$ & Positive & $\begin{array}{c}\text { Paenibacillus } \\
\text { thiaminolyticus or } \\
\text { popilliae }\end{array}$ & $2.22 \mathrm{E}+04$ & Paenibacillus sp. & 3 \\
\hline 2059 & $\mathrm{PIH}$ & Negative & no amplification & 0 & no amplification & 0 \\
\hline 2061 & $\mathrm{PIH}$ & Negative & no amplification & 0 & no amplification & 0 \\
\hline 2062 & $\mathrm{PIH}$ & Negative & no amplification & 0 & no amplification & 0 \\
\hline 2065 & $\mathrm{PIH}$ & Negative & no amplification & 0 & no amplification & 0 \\
\hline 2066 & $\mathrm{PIH}$ & Positive & $\begin{array}{c}\text { Paenibacillus } \\
\text { thiaminolyticus or } \\
\text { popilliae }\end{array}$ & $9.22 \mathrm{E}+04$ & Paenibacillus sp. & 3 \\
\hline 2068 & $\mathrm{PIH}$ & Negative & no amplification & 0 & no amplification & 0 \\
\hline 2071 & $\mathrm{PIH}$ & Negative & no amplification & 0 & no amplification & 0 \\
\hline 2072 & $\mathrm{PIH}$ & Negative & no amplification & $9.46 \mathrm{E}+05$ & no amplification & 1 \\
\hline 2073 & $\mathrm{PIH}$ & Positive & $\begin{array}{c}\text { Paenibacillus } \\
\text { thiaminolyticus or } \\
\text { popilliae }\end{array}$ & $1.37 E+05$ & $\begin{array}{l}\text { Bacteroides and } \\
\text { Paenibacillus sp. }\end{array}$ & 3 \\
\hline 2074 & $\mathrm{PIH}$ & Positive & $\begin{array}{c}\text { Paenibacillus } \\
\text { thiaminolyticus or } \\
\text { popilliae }\end{array}$ & $6.19 \mathrm{E}+05$ & Paenibacillus sp. & 3 \\
\hline 2076 & $\mathrm{PIH}$ & Positive & $\begin{array}{c}\text { Paenibacillus } \\
\text { thiaminolyticus or } \\
\text { popilliae }\end{array}$ & $1.56 \mathrm{E}+04$ & Paenibacillus sp. & 3 \\
\hline
\end{tabular}




\begin{tabular}{|c|c|c|c|c|c|c|}
\hline 2078 & $\mathrm{PIH}$ & Positive & $\begin{array}{c}\text { Paenibacillus } \\
\text { thiaminolyticus or } \\
\text { popilliae }\end{array}$ & $7.64 \mathrm{E}+05$ & Paenibacillus sp. & 3 \\
\hline 2079 & $\mathrm{PIH}$ & Negative & no amplification & 0 & no amplification & 0 \\
\hline 2080 & $\mathrm{PIH}$ & Negative & no amplification & 0 & no amplification & 0 \\
\hline 2081 & $\mathrm{PIH}$ & Negative & no amplification & 0 & no amplification & 0 \\
\hline 2086 & $\mathrm{PIH}$ & Negative & no amplification & 0 & no amplification & 0 \\
\hline 2087 & $\mathrm{PIH}$ & Negative & no amplification & 0 & no amplification & 0 \\
\hline 2088 & $\mathrm{PIH}$ & Negative & no amplification & 0 & no amplification & 0 \\
\hline 2089 & $\mathrm{PIH}$ & Positive & Mixed taxa & $2.33 E+03$ & $\begin{array}{c}\text { Staphylococcus } \\
\text { and Paenibacillus } \\
\text { sp. }\end{array}$ & 2 \\
\hline 2090 & $\mathrm{PIH}$ & Positive & $\begin{array}{c}\text { Paenibacillus } \\
\text { thiaminolyticus or } \\
\text { popilliae }\end{array}$ & $2.93 E+05$ & Paenibacillus sp. & 3 \\
\hline 2091 & $\mathrm{PIH}$ & Negative & no amplification & 0 & no amplification & 0 \\
\hline 2093 & $\overline{\mathrm{PIH}}$ & Negative & no amplification & 0 & no amplification & 0 \\
\hline 2096 & $\mathrm{PIH}$ & Positive & $\begin{array}{c}\text { Paenibacillus } \\
\text { thiaminolyticus or } \\
\text { popilliae }\end{array}$ & $2.79 E+03$ & Paenibacillus sp. & 3 \\
\hline 2097 & $\mathrm{PIH}$ & Positive & Mixed taxa & 0 & $\begin{array}{l}\text { Streptococcus } \\
\text { sp. }\end{array}$ & 0 \\
\hline 2001 & $\mathrm{NPIH}$ & Negative & no amplification & 0 & no amplification & 0 \\
\hline 2004 & $\mathrm{NPIH}$ & Negative & no amplification & 0 & no amplification & 0 \\
\hline 2005 & $\mathrm{NPIH}$ & Negative & no amplification & 0 & no amplification & 0 \\
\hline 2010 & $\mathrm{NPIH}$ & Negative & no amplification & 0 & no amplification & 0 \\
\hline 2011 & $\overline{N P I H}$ & Negative & no amplification & 0 & no amplification & 0 \\
\hline 2013 & $\mathrm{NPIH}$ & Negative & no amplification & 0 & no amplification & 0 \\
\hline 2016 & $\mathrm{NPIH}$ & Positive & Clostridiales sp. & 0 & Burkholderia sp. & 0 \\
\hline 2019 & $\mathrm{NPIH}$ & Negative & no amplification & 0 & no amplification & 0 \\
\hline 2021 & $\mathrm{NPIH}$ & Negative & no amplification & 0 & no amplification & 0 \\
\hline 2022 & $\mathrm{NPIH}$ & Negative & no amplification & 0 & no amplification & 0 \\
\hline 2031 & $\mathrm{NPIH}$ & Negative & no amplification & 0 & no amplification & 0 \\
\hline 2034 & $\mathrm{NPIH}$ & Negative & no amplification & 0 & no amplification & 0 \\
\hline 2037 & $\mathrm{NPIH}$ & Negative & no amplification & 0 & no amplification & 0 \\
\hline 2038 & $\mathrm{NPIH}$ & Negative & no amplification & 0 & no amplification & 0 \\
\hline 2042 & $\mathrm{NPIH}$ & Negative & no amplification & 0 & no amplification & 0 \\
\hline 2047 & $\mathrm{NPIH}$ & Negative & no amplification & 0 & no amplification & 0 \\
\hline 2049 & $\mathrm{NPIH}$ & Negative & no amplification & 0 & no amplification & 0 \\
\hline 2058 & $\mathrm{NPIH}$ & Negative & no amplification & 0 & no amplification & 0 \\
\hline 2060 & $\mathrm{NPIH}$ & Negative & no amplification & 0 & no amplification & 0 \\
\hline 2063 & $\mathrm{NPIH}$ & Positive & Bacillus sp. & 0 & Bacillus sp. & 0 \\
\hline
\end{tabular}


medRxiv preprint doi: https://doi.org/10.1101/2020.08.03.20167544; this version posted August 4, 2020. The copyright holder for this preprint (which was not certified by peer review) is the author/funder, who has granted medRxiv a license to display the preprint in perpetuity.

All rights reserved. No reuse allowed without permission.

\begin{tabular}{|c|c|c|c|c|c|c|}
\hline 2064 & $\mathrm{NPIH}$ & Negative & no amplification & 0 & no amplification & 0 \\
\hline 2067 & $\mathrm{NPIH}$ & Negative & no amplification & 0 & no amplification & 0 \\
\hline 2069 & $\mathrm{NPIH}$ & Negative & no amplification & 0 & no amplification & 0 \\
\hline 2070 & $\mathrm{NPIH}$ & Positive & Mixed taxa & 0 & Clostridiales sp. & 0 \\
\hline 2075 & $\mathrm{NPIH}$ & Negative & no amplification & 0 & no amplification & 0 \\
\hline 2077 & $\mathrm{NPIH}$ & Negative & no amplification & 0 & no amplification & 0 \\
\hline 2082 & NPIH & Negative & no amplification & 0 & no amplification & 0 \\
\hline 2083 & $\mathrm{NPIH}$ & Negative & no amplification & 0 & no amplification & 0 \\
\hline 2084 & $\mathrm{NPIH}$ & Negative & no amplification & 0 & no amplification & 0 \\
\hline 2085 & $\mathrm{NPIH}$ & Negative & no amplification & 0 & no amplification & 0 \\
\hline 2092 & $\mathrm{NPIH}$ & Negative & no amplification & 0 & no amplification & 0 \\
\hline 2094 & $\mathrm{NPIH}$ & Negative & no amplification & 0 & no amplification & 0 \\
\hline 2095 & NPIH & Negative & no amplification & 0 & no amplification & 0 \\
\hline 2098 & $\mathrm{NPIH}$ & Negative & no amplification & 0 & no amplification & 0 \\
\hline 2099 & $\mathrm{NPIH}$ & Negative & no amplification & 0 & no amplification & 0 \\
\hline 2100 & $\mathrm{NPIH}$ & Negative & no amplification & 0 & no amplification & 0 \\
\hline
\end{tabular}

Supplementary Table 2. Summary of results based on conventional PCR (CPCR) using 16S V1-V4 primers with cloning and sequencing, Paenibacillus genus-specific qPCR, and V4 MiSeq on DNA obtained from fresh frozen CSF from each PIH $(n=64)$ and NPIH $(n=36)$ subject and concordance between the three assays for the presence of Paenibacillus. 
medRxiv preprint doi: https://doi.org/10.1101/2020.08.03.20167544; this version posted August 4, 2020. The copyright holder for this preprint (which was not certified by peer review) is the author/funder, who has granted medRxiv a license to display the preprint in perpetuity.

Supplementary Table 3: Differential Abundance.

\begin{tabular}{|l|c|c|c|c|c|c|}
\hline Taxa & logFC & AveExp & $\mathbf{t}$ & p.value & $\begin{array}{c}\text { adjusted } \\
\text { p.value }\end{array}$ & B \\
\hline g_Paenibacillus & 4.8292 & 8.0664 & 4.1496 & 0.0001 & 0.0111 & 1.5032 \\
\hline g_Tepidimonas & 3.0803 & 8.4413 & 3.4537 & 0.0008 & 0.0645 & -0.6682 \\
\hline g_Rothia & 2.1504 & 1.9001 & 2.9372 & 0.0041 & 0.2178 & -2.0791 \\
\hline g_Micrococcus & 1.6369 & 1.6634 & 2.4435 & 0.0163 & 0.6476 & -3.2479 \\
\hline g_Anaerococcus & -1.2173 & 1.1405 & -2.1411 & 0.0347 & 0.6806 & -3.8703 \\
\hline g_Anoxybacillus & 1.0416 & 0.7633 & 2.0259 & 0.0454 & 0.6806 & -4.088 \\
\hline g_Moraxella & -0.4952 & 0.1783 & -1.914 & 0.0585 & 0.6806 & -4.2887 \\
\hline g_Actinomycetospora & -0.4519 & 0.1627 & -1.8299 & 0.0702 & 0.6806 & -4.4328 \\
\hline g_Gordonia & 0.4937 & 0.4333 & 1.8238 & 0.0712 & 0.6806 & -4.4428 \\
\hline no_match & -0.6577 & 12.7805 & -1.8053 & 0.074 & 0.6806 & -4.4736 \\
\hline
\end{tabular}

Supplementary Table 3. Differential abundance. Statistical results from 16S Differential Abundance Testing using V1-V2. Counts were aggregated to the genera level and a log-normal regression model was applied using limma (106) with abundance as the outcome variable and indication status as the independent variable. The ten genera with the highest B-statistic are reported. 
medRxiv preprint doi: https://doi.org/10.1101/2020.08.03.20167544; this version posted August 4, 2020. The copyright holder for this preprint (which was not certified by peer review) is the author/funder, who has granted medRxiv a license to display the preprint in perpetuity.

Supplementary Table 4: Viral Results.

\begin{tabular}{|c|c|c|c|c|c|c|c|c|}
\hline \multirow{3}{*}{$\begin{array}{l}\text { Viral Summary } \\
\text { Results } \\
\\
\text { Virus }\end{array}$} & \multicolumn{2}{|c|}{ VirCapSeq-VERT } & \multicolumn{2}{|c|}{ RNA-Seq } & \multicolumn{4}{|l|}{ PCR } \\
\hline & $\begin{array}{l}\text { PIH } \\
(64)\end{array}$ & $\begin{array}{l}\text { NPIH } \\
(36)\end{array}$ & $\begin{array}{l}\text { PIH } \\
(64)\end{array}$ & $\begin{array}{l}\text { NPIH } \\
(36)\end{array}$ & PIH (n) & & NPIH ( & \\
\hline & \multicolumn{2}{|l|}{ CSF } & \multicolumn{2}{|l|}{ CSF } & Blood & CSF & Blood & CSF \\
\hline $\begin{array}{l}\text { Human Herpesvirus } \\
5(\mathrm{CMV})\end{array}$ & 8 & 0 & 4 & 0 & $18(64)$ & $8(64)$ & $9(35)$ & $0(36)$ \\
\hline $\begin{array}{l}\text { Human } \\
\text { Papillomavirus }\end{array}$ & 8 & 8 & 0 & 0 & $0(11)$ & $0(11)$ & $0(8)$ & $0(8)$ \\
\hline $\begin{array}{l}\text { Human Pegivirus / } \\
\text { GBV-C }\end{array}$ & 3 & 1 & 0 & 0 & & & & \\
\hline $\begin{array}{l}\text { Human Herpesvirus } \\
6 \mathrm{~A}\end{array}$ & 1 & 0 & 0 & 0 & & & & \\
\hline $\begin{array}{l}\text { Human Herpesvirus } \\
6 \mathrm{~B}\end{array}$ & 1 & 2 & 0 & 0 & & & & \\
\hline Human Rotavirus & 1 & 1 & 0 & 0 & & & & \\
\hline Torque Teno Virus & 2 & 1 & 0 & 0 & & & & \\
\hline
\end{tabular}




\begin{tabular}{|l|l|l|l|l|l|l|l|l|}
\hline $\begin{array}{l}\text { Human Parvovirus } \\
\text { (B19/V9) }\end{array}$ & 1 & 0 & 0 & 0 & & & & \\
\hline Norovirus & 1 & 0 & 0 & 0 & & & & \\
\hline $\begin{array}{l}\text { Merkel Cell } \\
\text { Polyomavirus }\end{array}$ & 0 & 1 & 0 & 0 & & & & \\
\hline Circovirus & 0 & 1 & 0 & 0 & & & & \\
\hline No Viral Reads & 43 & 21 & 60 & 36 & & & & \\
\hline
\end{tabular}

Supplementary Table 4. Summary of viral analysis using VirCapSeq, PCR, and RNAseq. All 100 CSF samples were tested with VirCapSeq-VERT and RNASeq. VirCapSeq-VERT detected evidence of 12 viruses present across 36 samples and RNASeq detected Humans Herpesvirus 5 (CMV) in 4 samples. The only virus that was confirmed through PCR at high abundance in our samples was CMV, for which we confirmed 5 of the 8 VirCapSeq-VERT samples and 3 of the 4 RNASeq positive CSF samples. CMV was only identified in the CSF from CMV blood positive PIH cases. PCR testing was performed for CMV and HPV. 
medRxiv preprint doi: https://doi.org/10.1101/2020.08.03.20167544; this version posted August 4, 2020. The copyright holder for this preprint (which was not certified by peer review) is the author/funder, who has granted medRxiv a license to display the preprint in perpetuity.

All rights reserved. No reuse allowed without permission.

Supplementary Table 5: Demographics with and without Paenibacillus.

\begin{tabular}{|c|c|c|c|c|}
\hline Characteristics & $\begin{array}{c}\text { All } \\
\text { patients } \\
n=100\end{array}$ & $\begin{array}{c}\text { PIH with } \\
\text { Paenibacillus } \\
n=38\end{array}$ & $\begin{array}{c}\text { PIH without } \\
\text { Paenibacillus } \\
n=26\end{array}$ & $\begin{array}{l}\text { NPIH } \\
n=36\end{array}$ \\
\hline Age in days, mean (SD) & $57(24)$ & $59(17)$ & $75(11)$ & $43(27)$ \\
\hline \multicolumn{5}{|l|}{ Sex } \\
\hline Male (\%) & $51(51)$ & $21(55)$ & $14(54)$ & $16(44)$ \\
\hline Female (\%) & $49(49)$ & $17(45)$ & $12(46)$ & $20(56)$ \\
\hline $\begin{array}{l}\text { Peripheral blood WBC } \\
{\left[1.0 \times 10^{3}\right] / \mu L \text {, mean (SD) }}\end{array}$ & $10.2(3.6)$ & $12(4)$ & $9.8(3)$ & $8.8(2.6)$ \\
\hline Lymphocytes \% & & $56.8(12.1)$ & $65.4(8.8)$ & $59.3(12.0)$ \\
\hline Granulocytes \% (SD) & & $33.6(13.6)$ & $26.0(8.4)$ & $31.1(10.9)$ \\
\hline 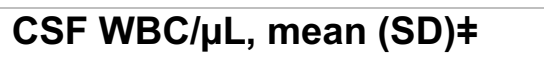 & $30(62)$ & $71(87)$ & $5(0)$ & $5(0.5)$ \\
\hline Glucose $\mathrm{mg} / \mathrm{dL}$ (SD) & & $32.4(16.8)$ & $30.5(7.6)$ & $38.8(13.5)$ \\
\hline Protein mg/dL (SD) & & $166.2(108.3)$ & $70.4(60.4)$ & $37.7(33.1)$ \\
\hline Hemoglobin g/dl, mean (SD) & $11.5(2.2)$ & $10.8(1.3)$ & $10.5(1.3)$ & $13.0(2.8)$ \\
\hline Hematocrit \%, mean (SD) & $36.8(7.4)$ & $34.4(4.1)$ & $33.6(4.2)$ & $41.6(9.3)$ \\
\hline \multicolumn{5}{|l|}{$\begin{array}{l}\text { CT scan scoring* } \\
\text { [no. and \% in each category] }\end{array}$} \\
\hline 0 & $32(33)$ & $1(3)$ & $7(27)$ & $24(69)$ \\
\hline 1 & $15(15)$ & $2(5)$ & $5(19)$ & $8(23)$ \\
\hline 2 & $13(13)$ & $5(14)$ & $5(19)$ & $3(9)$ \\
\hline 3 & $11(11)$ & $7(19)$ & $4(16)$ & $0(0)$ \\
\hline 4 & $27(26)$ & $22(59)$ & $5(19)$ & $0(0)$ \\
\hline \multicolumn{5}{|l|}{ HIV Exposure status [no. and \%] } \\
\hline Yes & $5(5)$ & $1(3)$ & $2(8)$ & $2(6)$ \\
\hline No & $95(95)$ & $37(97)$ & $24(92)$ & $34(94)$ \\
\hline
\end{tabular}

Supplementary Table 5. Comparison of demographic and clinical attributes between three groups: NPIH, PIH patients infected with Paenibacillus and PIH patients without Paenibacillus. $\mathrm{PIH}$ patients with Paenibacillus were more likely to be younger compared to those without Paenibacillus but there were no gender differences between these three groups. To investigate if the biomarkers of active inflammation were different between the three groups, we analyzed white blood cell (WBC) count. WBC from peripheral blood and CSF were significantly higher in the PIH group with Paenibacillus compared to other groups. However, the Paenibacillus group did not show a difference in hemoglobin or hematocrit concentration when compared to PIH without Paenibacillus. Preoperative computed tomography (CT) scans were available for 98 patients (98\%). Of these, patients in the PIH group with Paenibacillus were more likely to have a higher CT scan score indicative of brain abscess, calcifications, loculations and septations $(p<0.0001)$. However, there were no significant differences in gender and human 
medRxiv preprint doi: https://doi.org/10.1101/2020.08.03.20167544; this version posted August 4, 2020. The copyright holder for this preprint (which was not certified by peer review) is the author/funder, who has granted medRxiv a license to display the preprint in perpetuity.

All rights reserved. No reuse allowed without permission.

immunodeficiency virus (HIV) frequency between the groups. Continuous demographic variables were evaluated using the non-parametric Wilcoxon rank-sum (2-group comparisons) and Kruskal-Wallis (>2 groups) tests following Shapiro-Wilk's test for normality, unless otherwise stated. Fisher's exact test was performed for categorical variables. 
medRxiv preprint doi: https://doi.org/10.1101/2020.08.03.20167544; this version posted August 4, 2020. The copyright holder for this preprint (which was not certified by peer review) is the author/funder, who has granted medRxiv a license to display the preprint in perpetuity.

Supplementary Table 6: Paenibacillus vs CMV.

\begin{tabular}{|c|c|c|c|}
\hline \multicolumn{2}{|c|}{ CSF } & PIH & NPIH \\
\hline CMV - & Paeni + & 32 & 2 \\
\hline & Paeni - & 24 & 34 \\
\hline CMV + & Paeni + & 6 & 0 \\
\hline & Paeni - & 2 & 0 \\
\hline
\end{tabular}

\begin{tabular}{|c|c|c|c|}
\hline Blood & CSF & PIH & NPIH \\
\hline CMV - & Paeni + & 28 & 1 \\
\hline & Paeni - & 18 & 25 \\
\hline CMV + & Paeni + & 10 & 1 \\
\hline & Paeni - & 8 & 8 \\
\hline
\end{tabular}

Supplementary Table 6. Contingency tables for the prevalence of Paenibacillus positivity defined by $16 S$ and the detection of CMV found in CSF or blood respectively. Interestingly, we did not observe any CMV positive CSF in NPIH samples. 
Supplementary Table 7: CT Score vs CMV.

\begin{tabular}{|cccc|}
\hline LoculationsICMV CSF & Negative & Positive & Totals \\
\hline Negative & 43 & 1 & 44 \\
\hline Positive & 48 & 6 & 54 \\
\hline Totals & 91 & 7 & 98 \\
\hline
\end{tabular}

\begin{tabular}{|cccc|}
\hline Debris|CMV CSF & Negative & Positive & Totals \\
\hline Negative & 48 & 1 & 49 \\
\hline Positive & 43 & 6 & 49 \\
\hline Totals & 91 & 7 & 98 \\
\hline
\end{tabular}

\begin{tabular}{|cccc|}
\hline CalcificationlCMV CSF & Negative & Positive & Totals \\
\hline Negative & 47 & 1 & 48 \\
\hline Positive & 44 & 6 & 50 \\
\hline Totals & 91 & 7 & 98 \\
\hline
\end{tabular}

\begin{tabular}{|cccc|}
\hline AbscessICMV CSF & Negative & Positive & Totals \\
\hline Negative & 67 & 2 & 69 \\
\hline Positive & 24 & 5 & 29 \\
\hline Totals & 91 & 7 & 98 \\
\hline
\end{tabular}

Supplementary Table 7. Table of CT score composite features cross tabulated with CMV CSF status. Within the CMV negative population, $26 \%, 48 \%, 53 \%$, and $47 \%$ had signs of abscesses, calcifications, loculations and debris respectively. In contrast the CMV positive population, albeit with small numbers, $71 \%$ and $86 \%$ of patients had signs of abscesses or calcifications, loculations, or debris respectively. Controlling for Paenibacillus presence in an ordinal logistic regression did not demonstrate a significant odds ratio relating CMV positivity to elevated CT scan scores OR $(95 \% \mathrm{Cl})=3.30(0.52,29.66)$. 
Supplementary Table 8: Culture Media.

\begin{tabular}{|c|c|c|c|}
\hline Media & Volume of inoculum $(\boldsymbol{\mu l})$ & Conditions & Duration (Days) \\
\hline CHOC & 100 & $37^{\circ} \mathrm{C}, 5 \% \mathrm{CO}_{2}$ & 7 \\
\hline BAP & 100 & $37^{\circ} \mathrm{C}, 5 \% \mathrm{CO}_{2}$ & 7 \\
\hline MAC & 100 & $37^{\circ} \mathrm{C}, 5 \% \mathrm{CO}_{2}$ & 7 \\
\hline CMG & 200 & $37^{\circ} \mathrm{C}$, Ambient air & 14 \\
\hline PEDS & 250 & $37^{\circ} \mathrm{C}, \mathrm{BACTEC}$ instrument & 14 \\
\hline ANA & 50 & $37^{\circ} \mathrm{C}, \mathrm{BACTEC}$ instrument & 14 \\
\hline
\end{tabular}

Supplementary Table 8. Detailed description of the six different culture media with the respective inoculum volume, conditions and duration of culture. $\mathrm{BBL}^{\mathrm{TM}}$ Chocolate $\mathrm{Agar}(\mathrm{CHOC})$, $\mathrm{BBL}^{\mathrm{TM}}$ Sheep blood Agar (BAP), BBL ${ }^{\mathrm{TM}}$ MacConkey Agar (MAC), Chopped Meat Glucose Broth

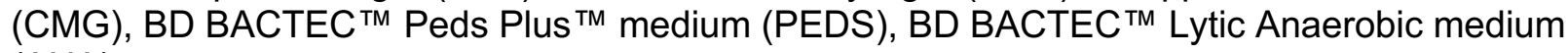
(ANA). 
Supplementary Table 9: Culture Results.

\begin{tabular}{|c|c|c|c|c|c|}
\hline Sample & $\begin{array}{l}\text { Positive } \\
\text { Culture }\end{array}$ & $\begin{array}{l}\text { Gram } \\
\text { Stain }\end{array}$ & $\begin{array}{c}\text { Subculture } \\
\text { (morphologies) }\end{array}$ & Maldi-TOF ID & $\begin{array}{l}\text { MALDI- } \\
\text { TOF } \\
\text { Score }\end{array}$ \\
\hline 2009 & ANA & GNR & None & Paenibacillus amyloliticus & 1.43 \\
\hline 2009 & $\mathrm{CMG}, \mathrm{CHOC}$ & GPR & N/A & Propionibacterium acnes & 2.08 \\
\hline 2033 & ANA & GVR & Yes (2) & $\begin{array}{l}\text { Paenibacillus thiaminolyticus } \\
\text { Paenibacillus thiaminolyticus }\end{array}$ & $\begin{array}{l}2.3 \\
1.38\end{array}$ \\
\hline 2051 & CMG & GNR/GPR & Yes (3) & $\begin{array}{l}\text { Bacillus okuhidensi } \\
\text { Bacillus halodurans } \\
\text { Propionibacterium acnes }\end{array}$ & $\begin{array}{l}2.29 \\
2.16 \\
2.20\end{array}$ \\
\hline 2086 & ANA & GPR & Yes (1) & Propionibacterium acnes & 2.22 \\
\hline 2086 & CMG & GPR/GNR & None & $\begin{array}{l}\text { Propionibacterium acnes } \\
\text { Dermobacter hominis }\end{array}$ & $\begin{array}{l}2.22 \\
1.83\end{array}$ \\
\hline 2092 & ANA & GPR & Yes (1) & Propionibacterium acnes & 2.15 \\
\hline 2084 & ANA & GPC & Yes (1) & Streptococcus salivarius & 1.96 \\
\hline 2006 & ANA (blind) & GNR & Yes (1) & Paenibacillus spp. & 1.83 \\
\hline 2025 & PED (blind) & GNR & Yes (1) & Bacillus infantis & 2.25 \\
\hline 2018 & ANA (blind) & GPR & Yes (1) & Propionibacterium acnes & 2.28 \\
\hline
\end{tabular}


medRxiv preprint doi: https://doi.org/10.1101/2020.08.03.20167544; this version posted August 4, 2020. The copyright holder for this preprint (which was not certified by peer review) is the author/funder, who has granted medRxiv a license to display the preprint in perpetuity.

All rights reserved. No reuse allowed without permission.

\begin{tabular}{|l|l|l|l|l|l|}
2081 & ANA (blind) & GPR & Yes (1) & Propionibacterium acnes & 2.26 \\
\hline
\end{tabular}

Supplementary Table 9. The culture and subculture results from 100 fresh frozen CSF patient samples. All 100 fresh frozen CSF samples were inoculated in 6 different media outlined in Table S8 and subcultured. Successful subcultures and solid media cultures were tested with MALDI-TOF for identification using 1.7 and 2.0 cut offs for genus and species identification respectively. For samples that were unable to grow on solid media MALDI-TOF was performed on the liquid culture. Further, negative liquid cultures were blindly subcultured (blind) and positive cultures were also tested with MALDI-TOF. (Supplementary Methods: Characterization for Organisms Recovered from Culture). Gram negative rods (GNR), Gram positive rods (GPR), Gram variable rods (BVR), Gram positive cocci (GPC), BBLTM Chocolate Agar (CHOC), BBLTM Sheep blood Agar (BAP), BBLTM MacConkey Agar (MAC), Chopped Meat Glucose Broth (CMG), BD BACTEC ${ }^{\mathrm{TM}}$ Peds Plus ${ }^{\mathrm{TM}}$ medium (PEDS), BD BACTEC ${ }^{\mathrm{TM}}$ Lytic Anaerobic medium (ANA). 
Supplementary Table 10: Biochemical testing of $\boldsymbol{P}$. thiaminolyticus.

\begin{tabular}{|c|c|c|c|c|c|}
\hline $\begin{array}{c}\text { Tube } \\
\#\end{array}$ & Test & Carbohydrate & $\begin{array}{c}\text { Case } \\
\text { report(107) }\end{array}$ & $\begin{array}{c}\text { Strain } \\
\text { B- } \\
4156\end{array}$ & $\begin{array}{c}\text { Clinical } \\
\text { Sample 2033 } \\
\text { Strain Mbale }\end{array}$ \\
\hline 0 & \multicolumn{2}{|c|}{ Control (NG = no growth) } & NG & NG & NG \\
\hline 1 & GLY & glycerol & + & + & + \\
\hline 2 & ERY & erythritol & - & - & - \\
\hline 3 & DARA & D-arabinose & - & - & - \\
\hline 4 & LARA & L-arabinose & - & - & - \\
\hline 5 & RIB & D-ribose & + & + & + \\
\hline 6 & DXYL & D-xylose & - & - & - \\
\hline 7 & LXYL & L-xylose & - & - & - \\
\hline 8 & ADO & D-adonitol & - & - & - \\
\hline 9 & MDX & $\begin{array}{l}\text { methyl- } \beta D- \\
\text { xylopyranoside }\end{array}$ & - & - & - \\
\hline 10 & GAL & D-galactose & + & $(+)$ & $(+)$ \\
\hline 11 & GLU & D-glucose & + & + & + \\
\hline 12 & FRU & D-fructose & + & + & + \\
\hline 13 & MNE & D-mannose & + & + & + \\
\hline 14 & SBE & L-sorbose & - & - & - \\
\hline 15 & RHA & L-rhamnose & - & - & - \\
\hline 16 & DUL & dulcitol & - & - & - \\
\hline 17 & INO & inositol & - & - & - \\
\hline 18 & MAN & D-mannitol & - & - & - \\
\hline 19 & SOR & D-sorbitol & - & - & - \\
\hline 20 & MDM & $\begin{array}{l}\text { methyl-(alpha)D- } \\
\text { mannopyranoside }\end{array}$ & - & - & - \\
\hline 21 & MDG & $\begin{array}{l}\text { methyl aD- } \\
\text { glucopyranoside }\end{array}$ & - & $(+)$ & $(+)$ \\
\hline 22 & NAG & $\begin{array}{l}\mathrm{N}- \\
\text { acetylglucosamine }\end{array}$ & + & + & + \\
\hline 23 & AMY & amygdalin & + & + & + \\
\hline 24 & ARB & arbutin & + & + & + \\
\hline 25 & ESC & esculin & + & + & + \\
\hline 26 & SAL & salicin & + & + & + \\
\hline 27 & CEL & D-cellobiose & - & $(+)$ & $(+)$ \\
\hline 28 & MAL & D-maltose & + & + & + \\
\hline 29 & LAC & $\begin{array}{l}\text { D-lactose (bovine } \\
\text { origin) }\end{array}$ & - & $(+)$ & $(+)$ \\
\hline 30 & MEL & D-melibiose & + & + & + \\
\hline 31 & SAC & D-saccharose & + & + & + \\
\hline
\end{tabular}




\begin{tabular}{|l|l|l|c|c|c|}
\hline 32 & TRE & D-trehalose & + & + & + \\
\hline 33 & INU & inulin & - & - & - \\
\hline 34 & MLZ & D-melezitose & - & $(+)$ & $(+)$ \\
\hline 35 & RAF & D-raffinose & + & + & + \\
\hline 36 & AMD & amidon & + & + & + \\
\hline 37 & GLYG & glycogen & + & + & - \\
\hline 38 & XLT & xylitol & - & - & - \\
\hline 39 & GEN & gentiobiose & + & + & + \\
\hline 40 & TUR & D-turanose & + & + & + \\
\hline 41 & LYX & D-lyxose & - & - & - \\
\hline 42 & TAG & D-tagatose & - & - & - \\
\hline 43 & DFUC & D-fucose & - & - & - \\
\hline 44 & LFUC & L-fucose & - & - & - \\
\hline 45 & DARL & D-arabitol & - & - & - \\
\hline 46 & LARL & L-arabitol & - & - & - \\
\hline 47 & GNT & $\begin{array}{l}\text { potassium } \\
\text { gluconate }\end{array}$ & + & $(+)$ & $(+)$ \\
\hline 48 & 2KG & $\begin{array}{l}\text { potassium 2- } \\
\text { ketogluconate }\end{array}$ & - & - & - \\
\hline 49 & 5KG & $\begin{array}{l}\text { potassium 5- } \\
\text { ketogluconate }\end{array}$ & - & - & - \\
\hline Likelihood of $\boldsymbol{P}$. thiaminolyticus & $\mathbf{5 7 . 5 \%}$ & $\mathbf{9 9 . 9 \%}$ & $\mathbf{9 9 . 8 \%}$ \\
\hline
\end{tabular}

NG: No growth

- Negative

+ Positive

$(+)$ low / late positive

24 Hours

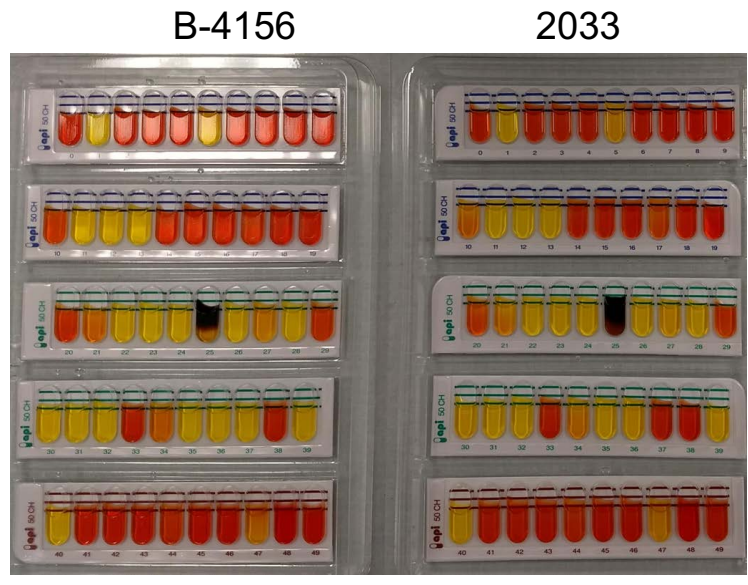

48 Hours

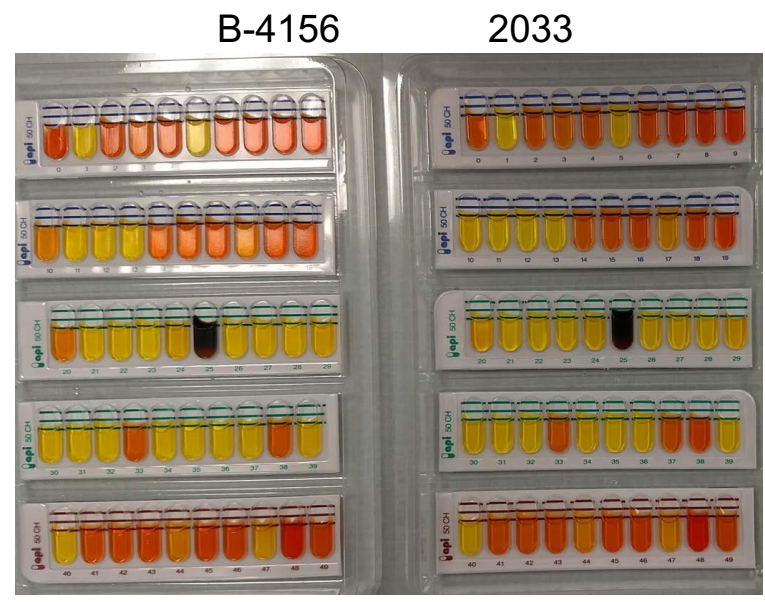


medRxiv preprint doi: https://doi.org/10.1101/2020.08.03.20167544; this version posted August 4, 2020. The copyright holder for this preprint (which was not certified by peer review) is the author/funder, who has granted medRxiv a license to display the preprint in perpetuity.

All rights reserved. No reuse allowed without permission.

Supplementary Table 10. Biochemical testing of $\boldsymbol{P}$. thiaminolyticus. API $50 \mathrm{CHB}$

biochemical results for $P$. thiaminolyticus BKBLC 2156 as previously reported in the case report of Ouyang et al (2010)(107), contrasted with our testing of reference type strain NRRL B-4156, and our clinical isolate from patient sample 2033 strain type Mbale. The reference strain NRRL B-4156, and our clinical isolate type strain Mbale, were both identified as $P$. thiaminolyticus with 99.8-99.9\% confidence (https://apiweb.biomerieux.com). The clinical strain was tested 3 times, and while there was some variability at $24 \mathrm{~h}$, it consistently identified as $\mathrm{P}$. thiaminolyticus with high confidence at $48 \mathrm{~h}$. 
Supplementary Table 11: Antibiotic Resistance.

\begin{tabular}{|l|c|c|c|c|}
\hline \multirow{2}{*}{ Antibiotic } & \multicolumn{2}{|c}{ P. thiaminolyticus } & \multicolumn{2}{c|}{ Paenibacillus spp. } \\
& MIC $(\boldsymbol{\mu g} / \mathrm{ml})$ & Interpretation* $^{*}$ & MIC $(\mu \mathrm{g} / \mathrm{ml})$ & Interpretation* $^{*}$ \\
\hline Vancomycin & 4 & $\mathrm{~S}$ & 0.125 & $\mathrm{~S}$ \\
\hline Ciprofloxacin & 0.064 & $\mathrm{~S}$ & 0.25 & $\mathrm{~S}$ \\
\hline Penicillin & 0.125 & $\mathrm{~S}$ & 1.0 & $\mathrm{R}$ \\
\hline Clindamycin & 0.5 & $\mathrm{~S}$ & 2.0 & $\mathrm{I}$ \\
\hline Ceftriaxon* & 0.5 & & 0.5 & \\
\hline Gentamycin & 2.0 & $\mathrm{~S}$ & 0.032 & $\mathrm{~S}$ \\
\hline Tetracycline & 0.25 & $\mathrm{~S}$ & 0.064 & $\mathrm{~S}$ \\
\hline
\end{tabular}

${ }^{*}$ S: Susceptible, R: Resistant, I: Intermediate

${ }^{* *}$ No interpretation by CLSI guidelines

Supplementary Table 11. Antibiotic Resistance testing of the available antibiotics in the Ugandan population was performed on two clinical isolates of Paenibacillus that grew aerobically, using standard E-test sensitivity and interpretations given for ones that were interpretable with Clinical and Laboratory Standards Institute (CLSI) guidelines. The $P$. Thiaminolyticus Mbale isolate, which appeared to represent most of our samples, showed no antibiotic resistance while the Paenibacillus spp. was identified as resistant to penicillin with intermediate resistance to clindamycin. 
Supplementary Table 12: Virulence Testing.

\begin{tabular}{|c|c|c|c|}
\hline $\begin{array}{c}\text { Inoculation Status } \\
\text { [no. and \% in each category] }\end{array}$ & $\begin{array}{c}\text { All mice } \\
\mathbf{n = 5 0}\end{array}$ & $\begin{array}{c}\text { Moribund or Died } \\
\mathbf{n = 1 6}\end{array}$ & $\begin{array}{c}\text { Normal } \\
\mathbf{n = 3 4}\end{array}$ \\
\hline Mbale strain & $26(52)$ & $16(62)$ & $10(38)$ \\
\hline Undiluted $\left(\sim 10^{9} \mathrm{CFU} / \mathrm{mL}\right)$ & $16 / 26$ & $15 / 16^{*}$ & $0 / 16$ \\
\hline Dilutions (below $\left.10^{9} \mathrm{CFU} / \mathrm{mL}\right)$ & $10 / 26$ & $0 / 10$ & $10 / 10$ \\
\hline Reference strain & $14(28)$ & $0(0)$ & $10(100)$ \\
\hline Normal saline & $10(20)$ & $0(0)$ & $100)$ \\
\hline
\end{tabular}

* One mouse infected with the Mbale strain demonstrated signs of illness, but spontaneously recovered after 2 days.

Supplementary Table 12. Summary of virulence testing. Of the 50 mice inoculated, only those receiving the Mbale strain displayed signs of sepsis and were moribund. The infection was only clinically evident at the highest undiluted dose (16/16). Diluted doses were not able to induce signs of infection $(0 / 10)$. 


\section{Supplementary References}

56. J. G. Caporaso, C. L. Lauber, W. A. Walters, D. Berg-Lyons, J. Huntley, N. Fierer, S. M. Owens, J. Betley, L. Fraser, M. Bauer, N. Gormley, J. A. Gilbert, G. Smith, R. Knight, Ultra-high-throughput microbial community analysis on the Illumina HiSeq and MiSeq platforms. ISME J 6, 1621-1624 (2012).

57. S. S. Chang, H. L. Hsu, J. C. Cheng, C. P. Tseng, An efficient strategy for broad-range detection of low abundance bacteria without DNA decontamination of PCR reagents. PLoS One 6, e20303 (2011).

58. N. D. Olson, N. Shah, J. Kancherla, J. Wagner, J. N. Paulson, H. Corrada-Bravo, metagenomeFeatures: An R package for working with 16S rRNA reference databases and marker-gene survey feature data. Bioinformatics, (2019).

59. N. D. Olson, J. N. Paulson, and H. Corrada-Bravo., greengenes13.5MgDb (version 2.0). Bioconductor. , (2017).

60. J. G. Caporaso, J. Kuczynski, J. Stombaugh, K. Bittinger, F. D. Bushman, E. K. Costello, N. Fierer, A. G. Pena, J. K. Goodrich, J. I. Gordon, G. A. Huttley, S. T. Kelley, D. Knights, J. E. Koenig, R. E. Ley, C. A. Lozupone, D. McDonald, B. D. Muegge, M. Pirrung, J. Reeder, J. R. Sevinsky, P. J. Turnbaugh, W. A. Walters, J. Widmann, T. Yatsunenko, J. Zaneveld, R. Knight, QIIME allows analysis of high-throughput community sequencing data. Nat Methods 7, 335-336 (2010).

61. T. Z. DeSantis, P. Hugenholtz, N. Larsen, M. Rojas, E. L. Brodie, K. Keller, T. Huber, D. Dalevi, P. Hu, G. L. Andersen, Greengenes, a chimera-checked 16S rRNA gene database and workbench compatible with ARB. Appl Environ Microbiol 72, 5069-5072 (2006).

62. B. J. Haas, D. Gevers, A. M. Earl, M. Feldgarden, D. V. Ward, G. Giannoukos, D. Ciulla, D. Tabbaa, S. K. Highlander, E. Sodergren, B. Methe, T. Z. DeSantis, C. Human Microbiome, J. F. Petrosino, R. Knight, B. W. Birren, Chimeric 16S rRNA sequence formation and detection in Sanger and 454-pyrosequenced PCR amplicons. Genome Res 21, 494-504 (2011).

63. Q. Wang, G. M. Garrity, J. M. Tiedje, J. R. Cole, Naive Bayesian classifier for rapid assignment of rRNA sequences into the new bacterial taxonomy. Appl Environ Microbiol 73, 5261-5267 (2007).

64. S. Salter, M. J. Cox, E. M. Turek, S. T. Calus, W. O. Cookson, M. F. Moffatt, P. Turner, J. Parkhill, N. Loman, a. W. Walker, "Reagent contamination can critically impact sequence-based microbiome analyses," (2014).

65. J. N. Paulson, O. C. Stine, H. C. Bravo, M. Pop, Differential abundance analysis for microbial marker-gene surveys. Nat Methods 10, 1200-1202 (2013).

66. Y. Benjamini, Y. Hochberg, Controlling the False Discovery Rate - a Practical and Powerful Approach to Multiple Testing. Journal of the Royal Statistical Society Series BMethodological 57, 289-300 (1995).

67. A. Bankevich, S. Nurk, D. Antipov, A. A. Gurevich, M. Dvorkin, A. S. Kulikov, V. M. Lesin, S. I. Nikolenko, S. Pham, A. D. Prjibelski, A. V. Pyshkin, A. V. Sirotkin, N. Vyahhi, G. Tesler, M. A. Alekseyev, P. A. Pevzner, SPAdes: a new genome assembly algorithm and its applications to single-cell sequencing. J Comput Biol 19, 455-477 (2012).

68. M. M. Walker, N. J. Talley, Review article: bacteria and pathogenesis of disease in the upper gastrointestinal tract - beyond the era of Helicobacter pylori. Alimentary Pharmacology \& Therapeutics 39, 767-779 (2014).

69. S. Koren, B. P. Walenz, K. Berlin, J. R. Miller, N. H. Bergman, A. M. Phillippy, Canu: scalable and accurate long-read assembly via adaptive k-mer weighting and repeat separation. Genome Res 27, 722-736 (2017). 
70. M. Nei, S. Kumar, Molecular evolution and phylogenetics. (Oxford University Press, Oxford ; New York, 2000), pp. xiv, 333 p.

71. N. Saitou, M. Nei, The neighbor-joining method: a new method for reconstructing phylogenetic trees. Mol Biol Evol 4, 406-425 (1987).

72. J. Felsenstein, Confidence Limits on Phylogenies: An Approach Using the Bootstrap. Evolution 39, 783-791 (1985).

73. M. Kimura, A simple method for estimating evolutionary rates of base substitutions through comparative studies of nucleotide sequences. J Mol Evol 16, 111-120 (1980).

74. C. Quast, E. Pruesse, P. Yilmaz, J. Gerken, T. Schweer, P. Yarza, J. Peplies, F. O. Glockner, The SILVA ribosomal RNA gene database project: improved data processing and web-based tools. Nucleic Acids Res 41, D590-596 (2013).

75. S. F. Altschul, W. Gish, W. Miller, E. W. Myers, D. J. Lipman, Basic local alignment search tool. Journal of molecular biology 215, 403-410 (1990).

76. D. Hyatt, G. L. Chen, P. F. Locascio, M. L. Land, F. W. Larimer, L. J. Hauser, Prodigal: prokaryotic gene recognition and translation initiation site identification. $B M C$ Bioinformatics 11, 119 (2010).

77. J. R. Kultima, S. Sunagawa, J. Li, W. Chen, H. Chen, D. R. Mende, M. Arumugam, Q. Pan, B. Liu, J. Qin, J. Wang, P. Bork, MOCAT: a metagenomics assembly and gene prediction toolkit. PLoS One 7, e47656 (2012).

78. R. C. Edgar, MUSCLE: a multiple sequence alignment method with reduced time and space complexity. BMC Bioinformatics 5, 113 (2004).

79. M. N. Price, P. S. Dehal, A. P. Arkin, FastTree 2--approximately maximum-likelihood trees for large alignments. PLoS One 5, e9490 (2010).

80. I. Letunic, P. Bork, Interactive tree of life (iTOL) v3: an online tool for the display and annotation of phylogenetic and other trees. Nucleic Acids Res 44, W242-245 (2016).

81. A. R. Wattam, D. Abraham, O. Dalay, T. L. Disz, T. Driscoll, J. L. Gabbard, J. J. Gillespie, R. Gough, D. Hix, R. Kenyon, D. Machi, C. Mao, E. K. Nordberg, R. Olson, R. Overbeek, G. D. Pusch, M. Shukla, J. Schulman, R. L. Stevens, D. E. Sullivan, V. Vonstein, A. Warren, R. Will, M. J. Wilson, H. S. Yoo, C. Zhang, Y. Zhang, B. W. Sobral, PATRIC, the bacterial bioinformatics database and analysis resource. Nucleic Acids Res 42, D581-591 (2014).

82. L. Zammarchi, M. G. Colao, A. Mantella, T. Capobianco, G. Mazzarelli, N. Ciccone, S. Tekle Kiros, E. Mantengoli, G. M. Rossolini, A. Bartoloni, Evaluation of a new rapid fluorescence immunoassay for the diagnosis of dengue and Zika virus infection. $J$ Clin Virol 112, 34-39 (2019).

83. T. Briese, A. Kapoor, N. Mishra, K. Jain, A. Kumar, O. J. Jabado, W. I. Lipkin, Virome Capture Sequencing Enables Sensitive Viral Diagnosis and Comprehensive Virome Analysis. mBio 6, e01491-01415 (2015).

84. B. Langmead, S. L. Salzberg, Fast gapped-read alignment with Bowtie 2. Nat Methods 9, 357-359 (2012).

85. B. Chevreux, T. Pfisterer, B. Drescher, A. J. Driesel, W. E. Muller, T. Wetter, S. Suhai, Using the miraEST assembler for reliable and automated mRNA transcript assembly and SNP detection in sequenced ESTs. Genome Res 14, 1147-1159 (2004).

86. B. Zweygberg Wirgart, M. Brytting, A. Linde, B. Wahren, L. Grillner, Sequence variation within three important cytomegalovirus gene regions in isolates from four different patient populations. J Clin Microbiol 36, 3662-3669 (1998).

87. W. Habbal, F. Monem, B. C. Gartner, Comparative evaluation of published cytomegalovirus primers for rapid real-time PCR: which are the most sensitive? J Med Microbiol 58, 878-883 (2009).

88. M. Lopper, T. Compton, Disulfide bond configuration of human cytomegalovirus glycoprotein B. J Virol 76, 6073-6082 (2002). 
medRxiv preprint doi: https://doi.org/10.1101/2020.08.03.20167544; this version posted August 4, 2020. The copyright holder for this preprint (which was not certified by peer review) is the author/funder, who has granted medRxiv a license to display the preprint in perpetuity. All rights reserved. No reuse allowed without permission.

89. M. K. Isaacson, T. Compton, Human cytomegalovirus glycoprotein B is required for virus entry and cell-to-cell spread but not for virion attachment, assembly, or egress. $J$ Virol 83, 3891-3903 (2009).

90. J. L. Sanchez, G. A. Storch, Multiplex, quantitative, real-time PCR assay for cytomegalovirus and human DNA. J Clin Microbiol 40, 2381-2386 (2002).

91. B. Ewing, L. Hillier, M. C. Wendl, P. Green, Base-calling of automated sequencer traces using phred. I. Accuracy assessment. Genome Res 8, 175-185 (1998).

92. B. Ewing, P. Green, Base-Calling of Automated Sequencer Traces UsingPhred.II. Error Probabilities. Genome Research 8, 186-194 (1998).

93. A. M. Bolger, M. Lohse, B. Usadel, Trimmomatic: a flexible trimmer for Illumina sequence data. Bioinformatics 30, 2114-2120 (2014).

94. H. Li, B. Handsaker, A. Wysoker, T. Fennell, J. Ruan, N. Homer, G. Marth, G. Abecasis, R. Durbin, S. Genome Project Data Processing, The Sequence Alignment/Map format and SAMtools. Bioinformatics 25, 2078-2079 (2009).

95. G. Benson, Tandem repeats finder: a program to analyze DNA sequences. Nucleic Acids Res 27, 573-580 (1999).

96. B. Flury, A First Course in Multivariate Statistics. Springer Texts in Statistics (Springer, 1997).

97. M. Rougemont, M. Van Saanen, R. Sahli, H. P. Hinrikson, J. Bille, K. Jaton, Detection of four Plasmodium species in blood from humans by $18 \mathrm{~S}$ rRNA gene subunit-based and species-specific real-time PCR assays. J Clin Microbiol 42, 5636-5643 (2004).

98. J. L. Burg, C. M. Grover, P. Pouletty, J. C. Boothroyd, Direct and sensitive detection of a pathogenic protozoan, Toxoplasma gondii, by polymerase chain reaction. $J$ Clin Microbiol 27, 1787-1792 (1989).

99. M. Kabiri, D. Steverding, Studies on the recycling of the transferrin receptor in Trypanosoma brucei using an inducible gene expression system. Eur J Biochem 267, 3309-3314 (2000).

100. D. R. Moser, L. V. Kirchhoff, J. E. Donelson, Detection of Trypanosoma cruzi by DNA amplification using the polymerase chain reaction. J Clin Microbiol 27, 1477-1482 (1989).

101. I. M. Campos, M. L. Uribe, C. Cuesta, A. Franco-Gallego, J. Carmona-Fonseca, A. Maestre, Diagnosis of gestational, congenital, and placental malaria in Colombia: comparison of the efficacy of microscopy, nested polymerase chain reaction, and histopathology. Am J Trop Med Hyg 84, 929-935 (2011).

102. T. Z. DeSantis, E. L. Brodie, J. P. Moberg, I. X. Zubieta, Y. M. Piceno, G. L. Andersen, High-density universal 16S rRNA microarray analysis reveals broader diversity than typical clone library when sampling the environment. Microb Ecol 53, 371-383 (2007).

103. M. A. Tanner, B. M. Goebel, M. A. Dojka, N. R. Pace, Specific ribosomal DNA sequences from diverse environmental settings correlate with experimental contaminants. Appl Environ Microbiol 64, 3110-3113 (1998).

104. T. J. White, T. D. Bruns, S. B. Lee, and J. W. Taylor, in PCR - Protocols and Applications - A Laboratory Manual. (Academic Press, 1990), pp. 315-322.

105. S. Weidner, W. Arnold, A. Puhler, Diversity of uncultured microorganisms associated with the seagrass Halophila stipulacea estimated by restriction fragment length polymorphism analysis of PCR-amplified 16S rRNA genes. Appl Environ Microbiol 62, 766-771 (1996).

106. M. E. Ritchie, B. Phipson, D. Wu, Y. Hu, C. W. Law, W. Shi, G. K. Smyth, limma powers differential expression analyses for RNA-sequencing and microarray studies. Nucleic Acids Res 43, e47 (2015).

107. J. Ouyang, Z. Pei, L. Lutwick, S. Dalal, L. Yang, N. Cassai, K. Sandhu, B. Hanna, R. L. Wieczorek, M. Bluth, M. R. Pincus, Case report: Paenibacillus thiaminolyticus: a new 
medRxiv preprint doi: https://doi.org/10.1101/2020.08.03.20167544; this version posted August 4, 2020. The copyright holder for this preprint (which was not certified by peer review) is the author/funder, who has granted medRxiv a license to display the preprint in perpetuity.

All rights reserved. No reuse allowed without permission.

cause of human infection, inducing bacteremia in a patient on hemodialysis. Ann Clin Lab Sci 38, 393-400 (2008). 